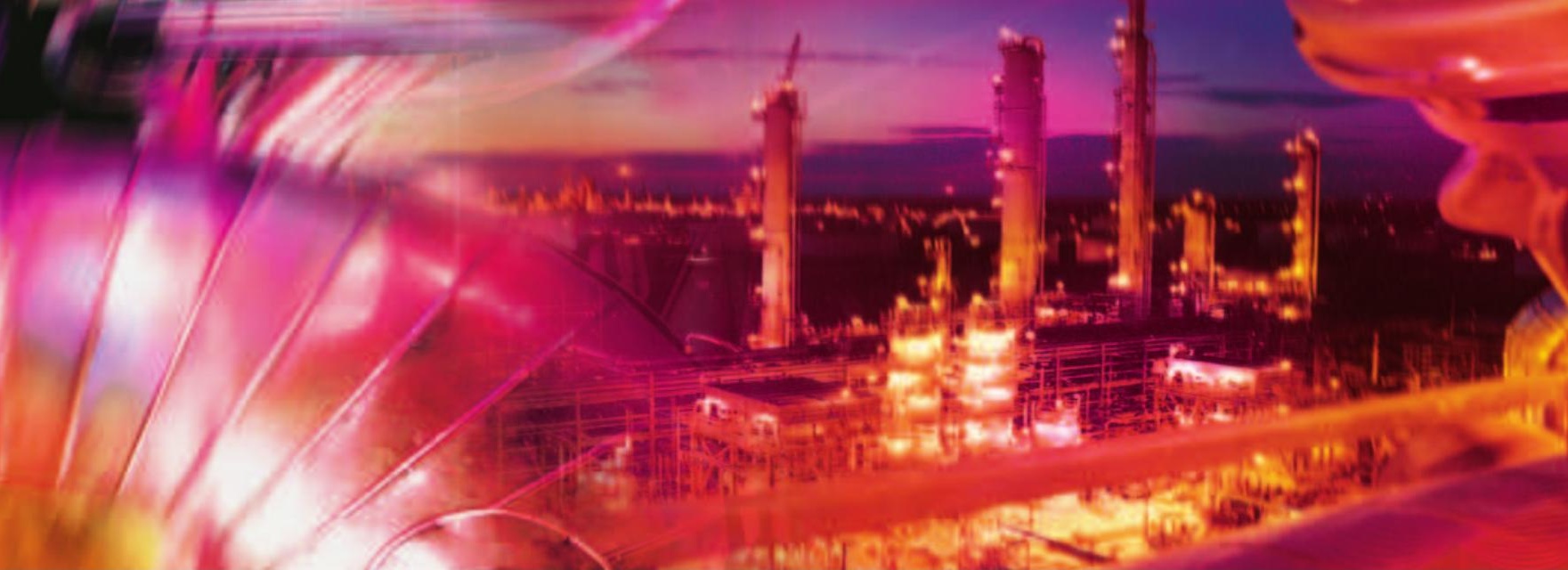

Iegernational

\title{
ENERGY TRANSITION FOR INDUSTRY: INDIA AND THE GLOBAL CONTEXT
}

INFORMATION PAPER

Nathalie Trudeau, Cecilia Tam,

Dagmar Graczyk and Peter Taylor

\section{$2011^{\text {samuang }}$}


The International Energy Agency (IEA), an autonomous agency, was established in November 1974. Its mandate is two-fold: to promote energy security amongst its member countries through collective response to physical disruptions in oil supply and to advise member countries on sound energy policy.

The IEA carries out a comprehensive programme of energy co-operation among 28 advanced economies, each of which is obliged to hold oil stocks equivalent to 90 days of its net imports. The Agency aims to:

- Secure member countries' access to reliable and ample supplies of all forms of energy; in particular, through maintaining effective emergency response capabilities in case of oil supply disruptions.

- Promote sustainable energy policies that spur economic growth and environmental protection in a global context - particularly in terms of reducing greenhouse-gas emissions that contribute to climate change.

- Improve transparency of international markets through collection and analysis of energy data.

- Support global collaboration on energy technology to secure future energy supplies and mitigate their environmental impact, including through improved energy

efficiency and development and deployment of low-carbon technologies.

- Find solutions to global energy challenges through engagement and dialogue with non-member countries, industry, international organisations and other stakeholders.

IEA member countries:

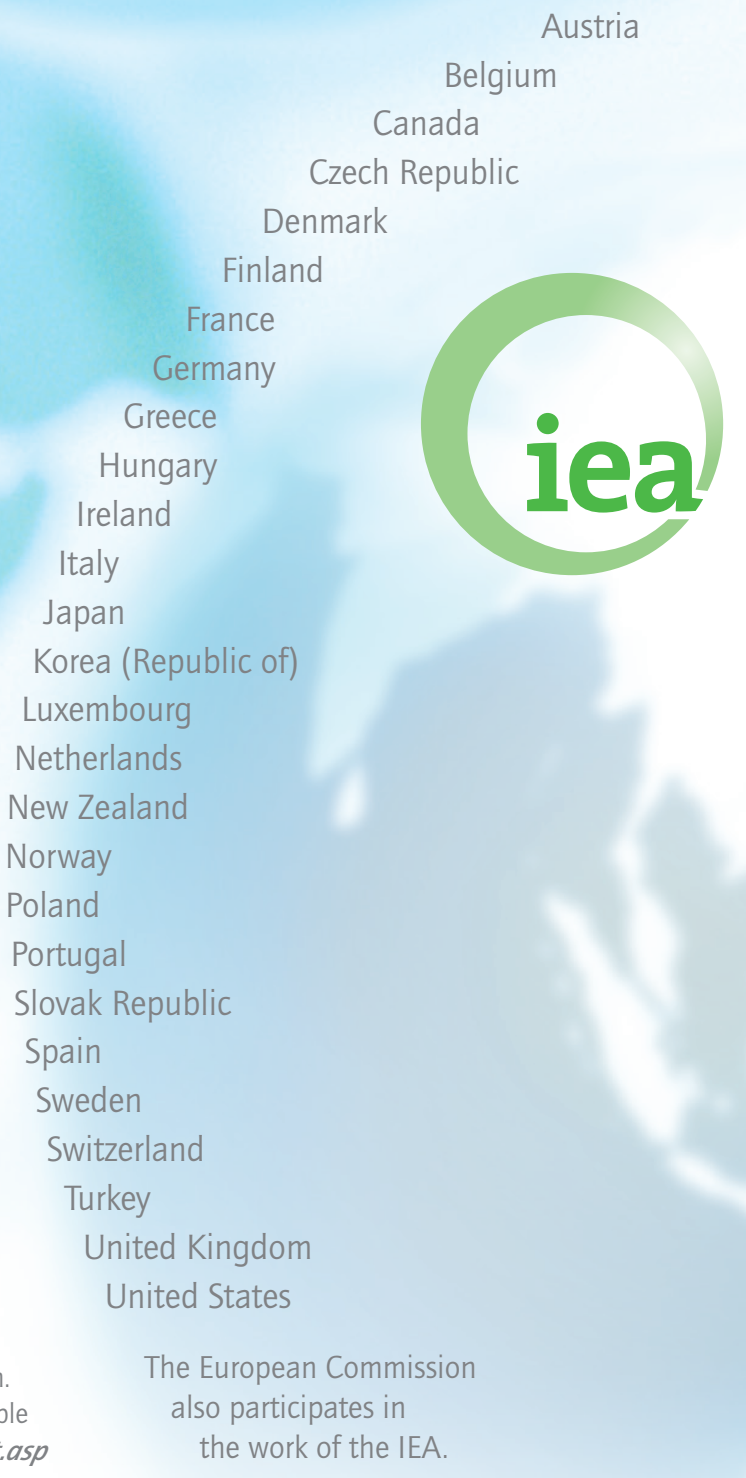

\section{International Energy Agency}

9 rue de la Fédération

75739 Paris Cedex 15, France

www.iea.org

Please note that this publication is subject to specific restrictions that limit its use and distribution. The terms and conditions are available online at www.iea.org/about/copyright.asp
International Energy Agency

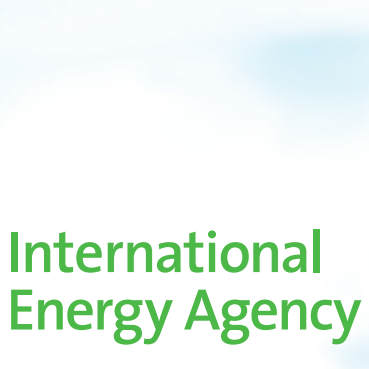




\section{ENERGY TRANSITION FOR INDUSTRY: INDIA AND THE GLOBAL CONTEXT}

This information paper was prepared for the Energy Technology Perspective Project of the International Energy Agency (IEA). It was drafted by the Energy Technology Policy Division of the IEA. This paper reflects the views of the IEA Secretariat, but does not necessarily reflect those of individual IEA member countries.

For further information, please contact Nathalie Trudeau at nathalie.trudeau@iea.org 



\section{Table of contents}

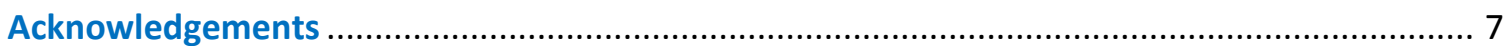

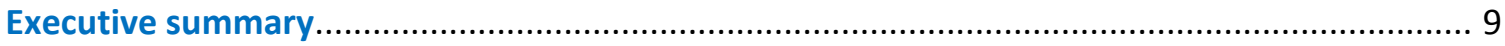

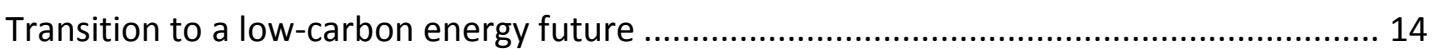

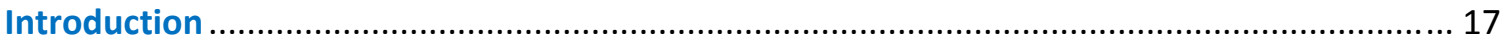

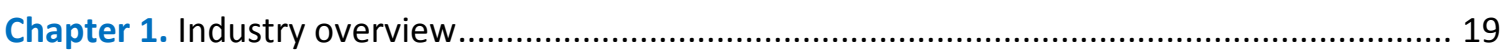

Energy and $\mathrm{CO}_{2}$ savings potential in India, based on best available technologies................ 21

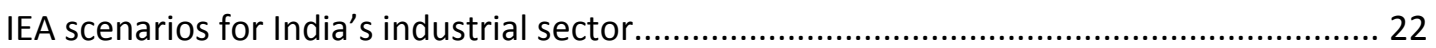

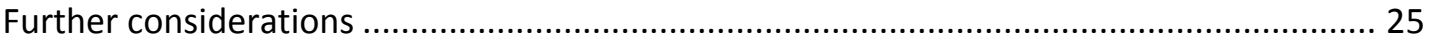

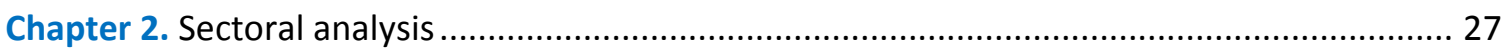

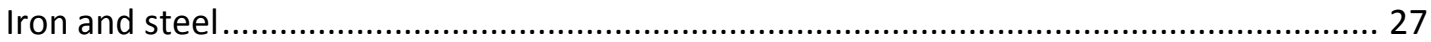

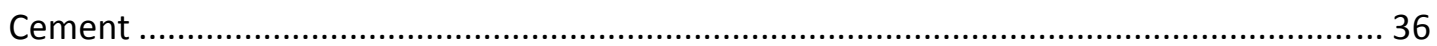

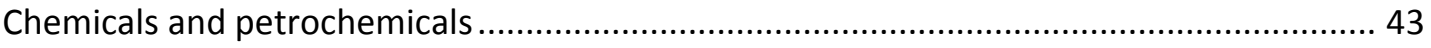

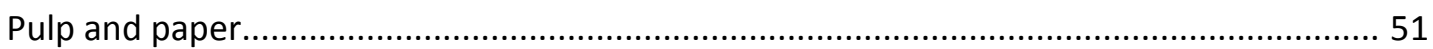

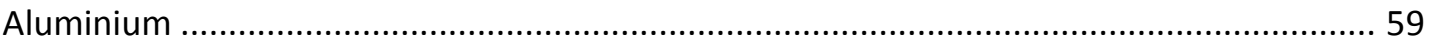

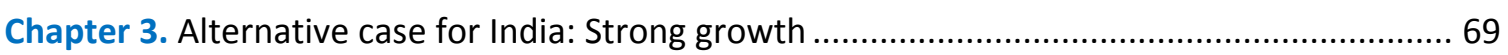

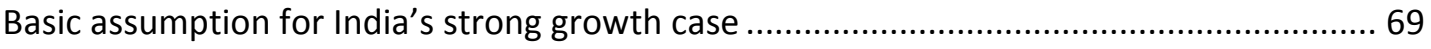

Materials consumption and production under the strong growth case ............................ 70

Scenarios for industrial energy use and $\mathrm{CO}_{2}$ emissions in the strong growth case............... 71

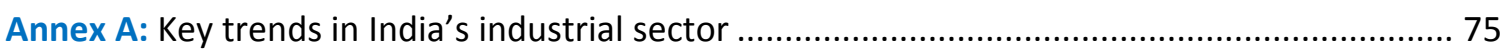

Annex B: Indicators for the chemical and petrochemical sector............................................. 81

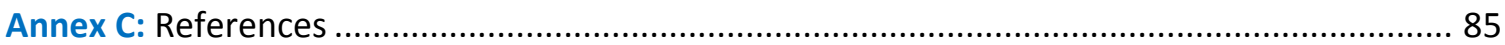

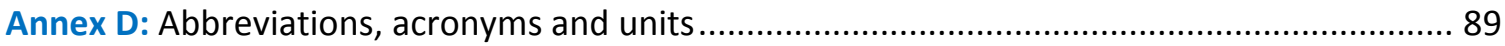

\section{List of figures}

Figure ES.1: India's direct $\mathrm{CO}_{2}$ emissions reduction by industry in the low-demand case ........... 11

Figure 1: Global $\mathrm{CO}_{2}$ emissions reduction by sector in the BLUE Scenario .................................. 17

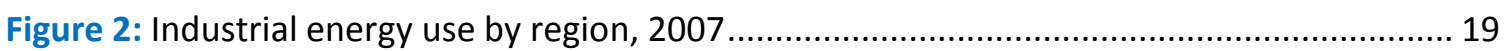

Figure 3: Industrial final energy consumption by sub-sector in India and in the world, 2007 ..... 20

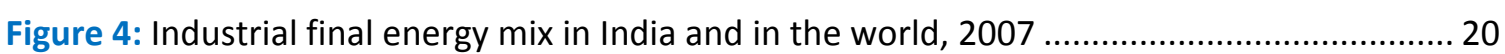

Figure 5: Materials production by region in the low- and high-demand cases ............................ 24

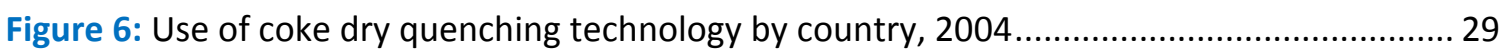

Figure 7: Reducing agents consumption in Blast Furnaces in the world 2007/2008*/2009** ... 29

Figure 8: Energy savings potential in 2007 for iron and steel, based on BAT ................................ 30

Figure 9: Iron and steel energy and direct $\mathrm{CO}_{2}$ intensity for low-demand scenarios,

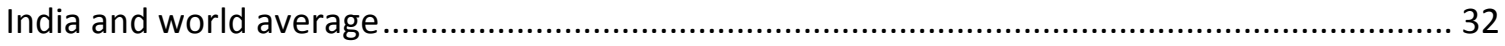

Figure 10: India's direct $\mathrm{CO}_{2}$ emissions reduction by technology option for iron and steel ........ 33

Figure 11: Global direct $\mathrm{CO}_{2}$ emissions reduction by technology option for iron and steel......... 33 
Figure 12: Regional contribution to reducing global direct $\mathrm{CO}_{2}$ emissions in iron and steel, low-demand case...

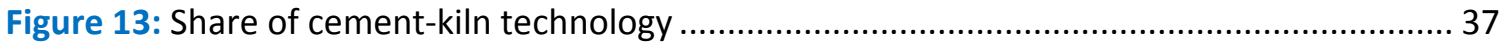

Figure 14: Thermal energy consumption per tonne of clinker ................................................. 38

Figure 15: Energy-savings potential in 2007 for cement, based on BAT ...................................... 39

Figure 16: Cement direct $\mathrm{CO}_{2}$ intensity in India and world average .......................................... 40

Figure 17: India's direct $\mathrm{CO}_{2}$ emissions reduction by technology option for cement ................... 41

Figure 18: Global direct $\mathrm{CO}_{2}$ emissions reduction by technology option for cement ................. 42

Figure 19: Regional contribution in global direct $\mathrm{CO}_{2}$ emissions in cement, low-demand case

Figure 20: Energy savings potential in 2007 for chemicals and petrochemicals, based on BPT.

Figure 21: India's chemical and petrochemical sector energy consumption,

including feedstock

Figure 22: India's direct $\mathrm{CO}_{2}$ emissions reduction by technology option for chemicals and petrochemicals

Figure 23: Global direct emissions reduction by technology option for chemicals and petrochemicals.

Figure 24: Regional contribution to reducing global direct $\mathrm{CO}_{2}$ emissions in chemicals and petrochemicals, low-demand case.

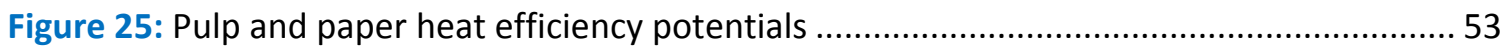

Figure 26: Energy savings potential in 2007 for the pulp and paper, based on BAT .................... 54

Figure 27: India's pulp and paper energy consumption by energy source and scenarios............ 56

Figure 28: India's direct $\mathrm{CO}_{2}$ emissions reduction by technology option for pulp and paper ...... 56

Figure 29: Global direct $\mathrm{CO}_{2}$ emissions reduction by technology option for pulp and paper ...... 57

Figure 30: Regional contribution to reduction in global direct $\mathrm{CO}_{2}$ emissions in pulp

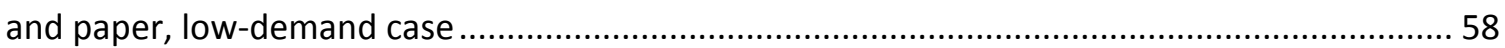

Figure 31: Specific energy consumption of metallurgical alumina production ............................6 60

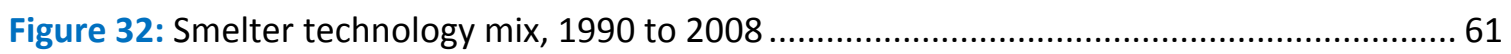

Figure 33: Energy savings potential in 2007 for aluminium, based on BAT.................................. 62

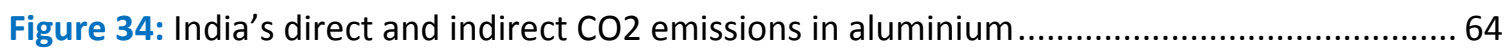

Figure 35: India's direct $\mathrm{CO}_{2}$ emissions reduction by technology option for aluminium .............. 64

Figure 36: Global direct $\mathrm{CO}_{2}$ emissions reduction by technology option for aluminium ..............65

Figure 37: Regional contribution to reducing global direct $\mathrm{CO}_{2}$ emissions in aluminium,

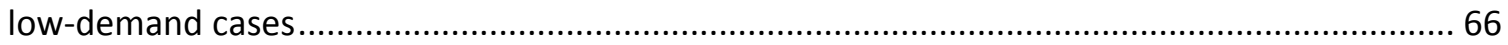

Figure 38: India's materials production under the ETP 2010 and strong growth cases ............... 71

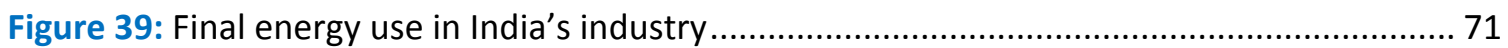

Figure 40: India's direct energy and process $\mathrm{CO}_{2}$ emissions by industrial sector.......................... 72

Figure 41: Options for reducing direct $\mathrm{CO}_{2}$ emissions from India's industry in the strong growth case 
List of tables

Table ES.1: India's direct CO2 emissions reduction by industry

Table ES.2: Production, energy consumption and $\mathrm{CO}_{2}$ emissions for India's iron and steel industry

Table ES.3: Production, energy consumption and $\mathrm{CO}_{2}$ emissions for India's cement industry

Table ES.4: Production, energy consumption and $\mathrm{CO}_{2}$ emissions for India's

chemical and petrochemical industry

Table ES.5: Production, energy consumption and $\mathrm{CO}_{2}$ emissions for

India's pulp and paper industry.

Table ES.6: Production, energy consumption and $\mathrm{CO}_{2}$ emissions for India's

aluminium industry

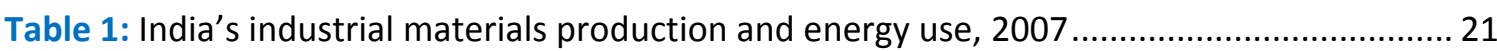

Table 2: India's materials demand in kilograms per capita (kg/cap) ...................................... 22

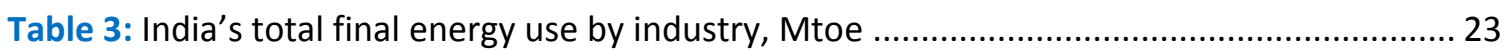

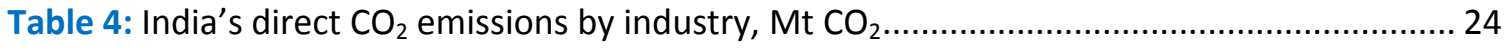

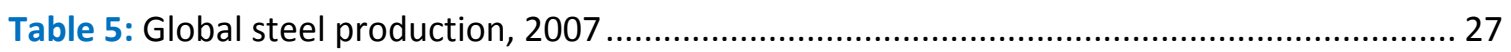

Table 6: India's iron and steel production by scenarios, Mt ................................................ 31

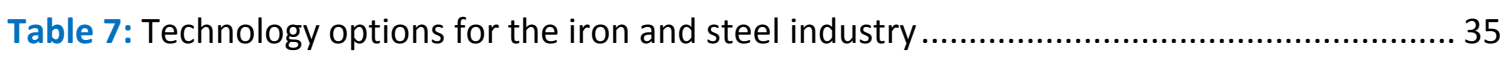

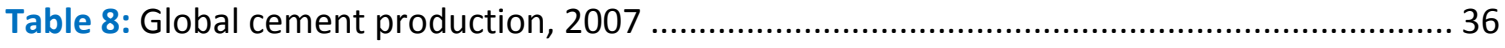

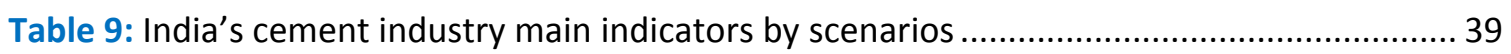

Table 10: Technology options for the cement industry .................................................... 43

Table 11: Potential energy improvements by BPT in the global chemical and petrochemical sector, 2006 (including both process energy and feedstock use) ${ }^{\mathrm{a}}$.......................45

Table 12: India's HVC, ammonia and methanol production ...............................................47

Table 13: Technology options for the chemical and petrochemical industry............................ 50

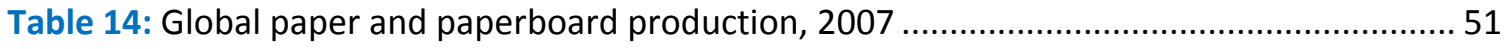

Table 15: India's pulp and paper production by scenarios .................................................... 55

Table 16: Technology options for the pulp and paper industry .........................................5 58

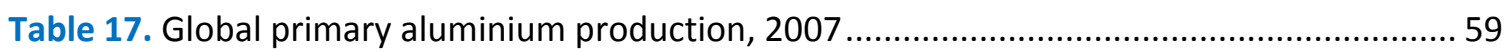

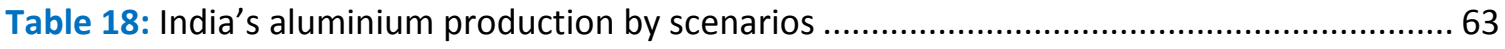

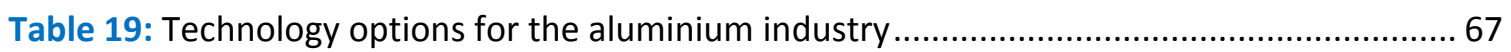

Table 20: GDP projections (\% per year, based on purchasing power parity) .............................69

Table 21: High-level indicators for India in ETP 2010 and strong growth cases .......................... 70

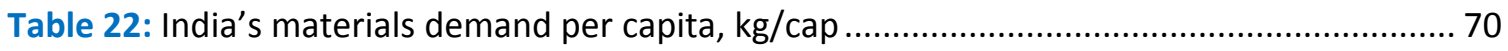

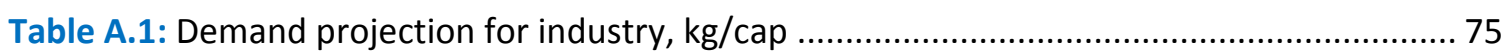

Table A.2: Materials production in the Baseline Scenario, Mt .......................................... 75

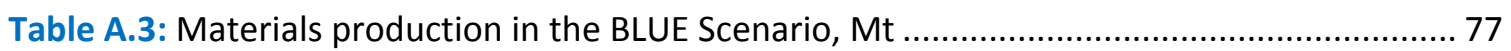

Table A.4: Final energy use in industry in the Baseline Scenario, Mtoe ................................... 79

Table A.5: Final energy use in industry in the BLUE Scenario, Mtoe ......................................... 79

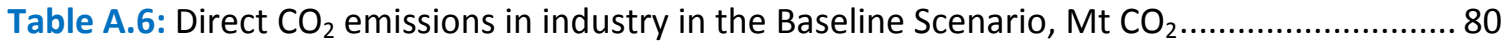


Table A.7: Direct CO2 emissions in industry in the BLUE Scenario, Mt CO2 80

Table B.1: BPT values on the specific energy consumption for the production of key chemicals (left: in final energy terms, denoted with index "f"; right: in primary energy terms, denoted with index " $p$ ") $)^{1}$

Page | 6 List of boxes

Box ES.1: Scenarios for the industrial sector 9

Box 1: The ETP 2010 scenarios 


\section{Acknowledgements}

This paper was prepared by staff of the International Energy Agency's Directorate of Sustainable Energy Policy and Technology in collaboration with the Directorate of Global Energy Dialogue.

A number of Indian experts have contributed significantly to improving the data and analysis presented in this paper. The IEA is grateful for the contribution of the India Energy Technology Perspectives Expert Group and wishes to thank the then Secretary, Ministry of Power, H. S. Brahma for establishing the India Energy Technology Expert Group to work with the IEA in preparing Energy Technology Perspectives 2010.

The expert group provided invaluable insights to our team to develop the India analysis. The IEA wish to thank for their important contributions: S.M. Dhiman, Member (Planning), Central Electricity Authority, chairman of the Expert group; Dilip Chenoy, Director General, Society of Indian Automobile Manufacturers (SIAM), chairman of the transportation sub-group; I.C.P. Keshari, Joint Secretary, Ministry of Power, chairman of the power sub-group; Dr. Ajay Mathur, Director General, Bureau of Energy Efficiency (BEE), chairman of the buildings sub-group; V. Raghuraman, Chief Adviser, Jaguar Overseas Ltd, chairman of the industry sub-group; A. S. Bakshi, Chief Engineer, Central Electricity Authority (CEA); Amarjeet Singh, Chief Engineer (C\&E), (CEA); Anita Gahlot, Deputy Director, CEA; and the convener and members of the sub-working groups:

Sub-Group for Power sector: Sewa Bhawan, R.K.Puram Chief Engineer, CEA (convener); Ms. Shruti Bhatia, Conferederation of Indian Industry (CII); Dr. Pradeep Dadhich, Senior Fellow, The Energy and Resources Institute (TERI); Mr. D.K.Dubey, AGM (CCT); Shri P.K. Goel, Director, Ministry of Power; Shri R.B. Grover, Scientific Adviser, Department of Atomic Energy (DAE); Shri D.K. Jain, Executive Director (Engg), NTPC Ltd; Dr. Sudhir Kapur, Member CII National Committee on Power and MD \& CEO-Country Strategy Business; Shri R.K. Kaul, Joint Advisor, Planning Commission; Sh. Sanjeev Mahajan, DGM (PE-CCT); Shri Sudhir Mohan, Advisor, Ministry of New and Renewable Energy (MNRE); Mr. B.H. Narayana, Addl. Dir., Central Power Research Institute (CPRI); Mr. Sunil Parwani, Addl. General Manager (Power Sector-Planning \& Monitoring), BHEL; Shri D.N. Prasad, Director, Ministry of Coal; Shri R.K. Sethi, Director, Ministry of Environment and Forests (MOEF); Sh. Arun Srivastava Scientific Officer/Engineer-H, (Strategic Planning Group), DAE.

Sub-Group for Buildings sector: Sh. Sanjay Seth, Energy Economist, BEE (Convener); Mr. Pradeep Kumar, Senior Fellow, TERI;Mr. K.I. Singh, GM (PE-Infrastructure Services), NTPC Ltd; Mr. S. Srinivas, Principal Counsellor, CII Green Business Centre, Hyderabad; Sh. Lekhan Thakkar, Vice President, Gujarat Urban Development Company Ltd. (GUDC); Dr. Vakil, CEPT University, Ahmedabad.

Sub-Group for Industry sector: Sh. Amarjeet Singh, Chief Engineer (C\&E), CEA (Convener); Shri B.N. Bankapur, Director (Ref), Indian Oil Corporation (IOC); Mr. M.R. Gandhi, Scientist-G, Central Salt \& Marine Chemical Research Institute;Dr. Satish Kumar, Chief of Party, USAID ECO-III Project, IRG; Sh. A. Panda, ED (S\&EP); Shri K.Murali, Director (Ref), Hindustan Petroleum Corporation Limited (HPCL); Sh. U. Venkata Ramana; Sh. Gautam Roy, GM(T); Mr. Ambuj Sagar, Indian Institute of Technology Delhi (IIT); Mr. Girish Sethi, Director (EET Division), TERI; Mr. S.P. Singh, GM (E\&P); Sh. S.B. Thakur, DGM (S\&EP); Mr. K.S. Venkatagiri, Principal Counsellor, Cll Green Business Centre, Hyderabad; Saurabh Yadav, Knowledge Management Specialist, BEE.

Sub-Group for Transport sector: Smt. Neerja Mathur, Chief Engineer (OM), CEA (Convener); Dr. Ajit Gupta, Retd. Advisor, MNRE; Mr. Saurabh Dalela, Addl. Dir, NATRiP; Sh. Dinesh Tyagi, Director (Tech) National Automotive Testing and R\&D Infrastructure Project (NATRiP). 
As well as all other participants at the Joint IEA-India Workshop on Regional Analysis of India who provided valuable comments and feedback on the Indian analysis including, but not limited to: Suresh Chander, Chief Engineer, CEA; K.K. Roy Chowdhury, Technical Associate, Cement Manufacturers' Association; Sriganesh Gandham, GM- Corporate R\&D, HPCL; Shri Alok kumar Goyal, Scientist, CPRI; Praveen Gupta, Director, CEA; Shri A.K. Gupta, Chief Engineer, CEA; Ravi Kapoor, USAID, ECO-III; Shri S. M. Kulkarni, Hindalco; A.K. Kulshreshtha, CDE (PE-Mech); Rajesh Kumar, Assistant Director, CEA; Mr. R.C Mall, IPMA; Dr. Nand, Fertiliser Association of India; P. Pal, Deputy GM, Engineering; Prof. V.K. Paul, Head of the Dept of Building Engineering \& Management; Shri M.S. Puri, Chief Engineer, CEA; Prof. P.K. Sarkar, Professor of Transport Planning; Naveen Kumar Sharma, GM, Grinding Unit, JK Lakshmi Cement Ltd.; K. Sheshadri, Assistant Director I, CEA; Shri Avtar Singh, Indian Paper Manufacturers Association (IPMA); K.I Singh, NTPC; Hardayal Singh, Deputy Director, CEA; Major Singh, Chief Engineer, CEA; V.K. Singh, Deputy Director, CEA; Dr. B.P. Thapliyal, Scientist, Central Power Research Institute (CPRI); C.B. Trivedi, Deputy Director, CEA; Anil K Varshney, Additional Vice President, BSES Rajdhani Power. 


\section{Executive summary}

Population growth, the modernisation of lifestyles, higher electrification rates and rapidly growing gross domestic product (GDP) in India drive a large increase in energy demand and put pressure on the security, reliability and affordability of energy supply, all of which are strongly linked to economic stability and development.

Globally, the erosion of energy security, the threat of disruptive climate change and the growing energy needs of the developing world all pose major challenges to energy decision makers. Energy security concerns are compounded by the increasingly urgent need to mitigate greenhouse-gas (GHG) emissions, including those relating to energy production and consumption. Current energy consumption and carbon dioxide $\left(\mathrm{CO}_{2}\right)$ emission trends run directly counter to the repeated warnings sent by the United Nations Intergovernmental Panel on Climate Change (IPCC), which concludes that only scenarios resulting in a $50 \%$ to $85 \%$ reduction of global $\mathrm{CO}_{2}$ emissions by 2050 (compared to 2000 levels) can limit the long-term global mean temperature rise to $2.0^{\circ} \mathrm{Celsius}\left({ }^{\circ} \mathrm{C}\right)$ to $2.4^{\circ} \mathrm{C}$ (IPCC, 2007).

The BLUE Scenario, developed by the International Energy Agency (IEA) and presented in Energy Technology Perspectives 2010 (ETP 2010) (IEA, 2010), examines the least-cost pathways for meeting the goal of reducing global energy-related $\mathrm{CO}_{2}$ emissions to $50 \%$ of 2005 levels by 2050 while also proposing measures to overcome technical and policy barriers. The BLUE Scenario is consistent with a long-term global rise in temperatures of $2.0^{\circ} \mathrm{C}$ to $3.0^{\circ} \mathrm{C}$, but only if the reduction in energy-related $\mathrm{CO}_{2}$ emissions is combined with deep cuts in other $\mathrm{GHG}$ emissions.

The scenario envisaged in the BLUE Scenario required $\mathrm{CO}_{2}$ emissions reduction across all the energyconsuming sectors. For industry, action is particularly crucial in the five most energy-intensive sectors: iron and steel; cement; chemicals and petrochemicals; pulp and paper; and aluminium. Globally, these sectors currently account for $77 \%$ of total direct $\mathrm{CO}_{2}$ emissions from industry; in India, they account for $56 \%$ of industrial energy consumption and $82 \%$ of direct $\mathrm{CO}_{2}$ emissions.

Box ES.1: Scenarios for the industrial sector

In ETP 2010, the IEA developed two different scenarios to analyse the industrial sector:

- The Baseline Scenario reflects developments that are expected on the basis of the energy policies that have been implemented or that have been approved and are to be implemented.

- The BLUE Scenario is target-driven and aims to achieve total emissions from the industry that are $24 \%$ lower in 2050 than the 2007 level.

Given the recent global economic crisis and uncertainties about projecting long-term growth in consumption of materials, the IEA also developed two different cases for each scenario: a lowdemand and a high-demand case for industrial materials. The industrial low-demand case is used to develop the global BLUE Scenario presented in ETP 2010.

Going beyond the analysis presented in the ETP 2010, the IEA has developed an alternative strong growth case for India. In this alternative case, the future growth of GDP is higher than that used for the development of ETP 2010.

Each country and region of the world will contribute differently to the reduction in emissions from the industrial sector, depending on the expected growth in production as well as the potential for energy and $\mathrm{CO}_{2}$ savings. 
In the case of India, total industrial energy consumption between 2007 and 2050 is expected to grow 3.5 times under the Baseline low-demand scenario and 4.2 times under the high-demand scenario. By implementing policies and measures defined in the BLUE Scenario, energy consumption in India would be higher in 2050 than in 2007, but between 121 million tonnes of oil equivalent (Mtoe) and 140 Mtoe lower than in the Baseline Scenario in 2050. In any scenario, the final energy use in 2030 and 2050 is significantly higher than today.

No single option can yield the necessary emission reductions. Energy efficiency alone will not be sufficient to reduce emissions in the industrial sector as the production growth in India by far exceeds the savings potential from energy efficiency. Government policies are needed to facilitate a transition to more efficient and lower-carbon technologies.

A significant reduction in $\mathrm{CO}_{2}$ emissions in Indian industry will only be possible if all sub-sectors contribute. Direct industry emissions can only be limited to an increase of $100 \%$ and $268 \%$ of current levels by 2050 if all sub-sectors significantly reduce their future emissions below the level anticipated in the Baseline Scenario (Table ES.1). In the BLUE Scenario, all sub-sectors need to reduce emissions substantially in 2050 and, for the overall industrial sector, obtain levels that are 46\% (low-demand case) and 51\% (high-demand case) lower than in the Baseline Scenario.

Table ES.1: India's direct $\mathrm{CO} 2$ emissions reduction by industry

\begin{tabular}{|c|c|c|c|c|c|c|c|}
\hline & $\begin{array}{c}\text { Total } \\
\text { industry }\end{array}$ & $\begin{array}{l}\text { Iron and } \\
\text { steel }\end{array}$ & Cement & $\begin{array}{l}\text { Chemicals and } \\
\text { petrochemicals }\end{array}$ & $\begin{array}{c}\text { Pulp } \\
\text { and } \\
\text { paper }\end{array}$ & Aluminium & $\begin{array}{c}\text { Other } \\
\text { industries }\end{array}$ \\
\hline \multicolumn{8}{|c|}{ Direct $\mathrm{CO}_{2}$ emissions in industry, $\mathrm{Mt} \mathrm{CO}_{2}$} \\
\hline 2007 & 413 & 151 & 128 & 48 & 8 & 4 & 74 \\
\hline \multicolumn{8}{|l|}{2050} \\
\hline Baseline low-demand & 1564 & 703 & 422 & 132 & 36 & 14 & 256 \\
\hline Baseline high-demand & 1852 & 858 & 483 & 173 & 62 & 21 & 256 \\
\hline Baseline strong growth & 2807 & 1153 & 1060 & 229 & 87 & 22 & 256 \\
\hline BLUE low-demand & 827 & 333 & 275 & 68 & 17 & 12 & 122 \\
\hline BLUE high-demand & 906 & 362 & 291 & 77 & 31 & 16 & 129 \\
\hline BLUE strong growth & 1519 & 532 & 676 & 119 & 50 & 22 & 122 \\
\hline \multicolumn{8}{|c|}{ Changes in BLUE 2050 vs. 2007} \\
\hline BLUE low-demand & $100 \%$ & $121 \%$ & $114 \%$ & $42 \%$ & $113 \%$ & $214 \%$ & $65 \%$ \\
\hline BLUE high-demand & $120 \%$ & $140 \%$ & $126 \%$ & $61 \%$ & $285 \%$ & $321 \%$ & $74 \%$ \\
\hline BLUE strong growth & $268 \%$ & $253 \%$ & $426 \%$ & $149 \%$ & $507 \%$ & $469 \%$ & $65 \%$ \\
\hline \multicolumn{8}{|c|}{ Changes in BLUE 2050 vs. Baseline 2050} \\
\hline BLUE low-demand & $-47 \%$ & $-53 \%$ & $-35 \%$ & $-48 \%$ & $-52 \%$ & $-16 \%$ & $-53 \%$ \\
\hline BLUE high-demand & $-51 \%$ & $-58 \%$ & $-40 \%$ & $-55 \%$ & $-49 \%$ & $-24 \%$ & $-50 \%$ \\
\hline BLUE strong growth & $-46 \%$ & $-54 \%$ & $-36 \%$ & $-48 \%$ & $-43 \%$ & $-1 \%$ & $-53 \%$ \\
\hline
\end{tabular}

Each industrial sub-sector will contribute to limit the growth in direct $\mathrm{CO}_{2}$ emissions in India under the BLUE low-demand scenario (Figure ES.1). Direct $\mathrm{CO}_{2}$ emissions reduction is limited in the aluminium sector given its high share of electricity use. The iron and steel sector will contribute the 
most to the reduction. The scenario is consistent with a $50 \%$ reduction in global $\mathrm{CO}_{2}$ emissions and a $24 \%$ reduction in the global industry sector in 2050, compared to the 2007 level.

Figure ES.1: India's direct $\mathrm{CO}_{2}$ emissions reduction by industry in the low-demand case

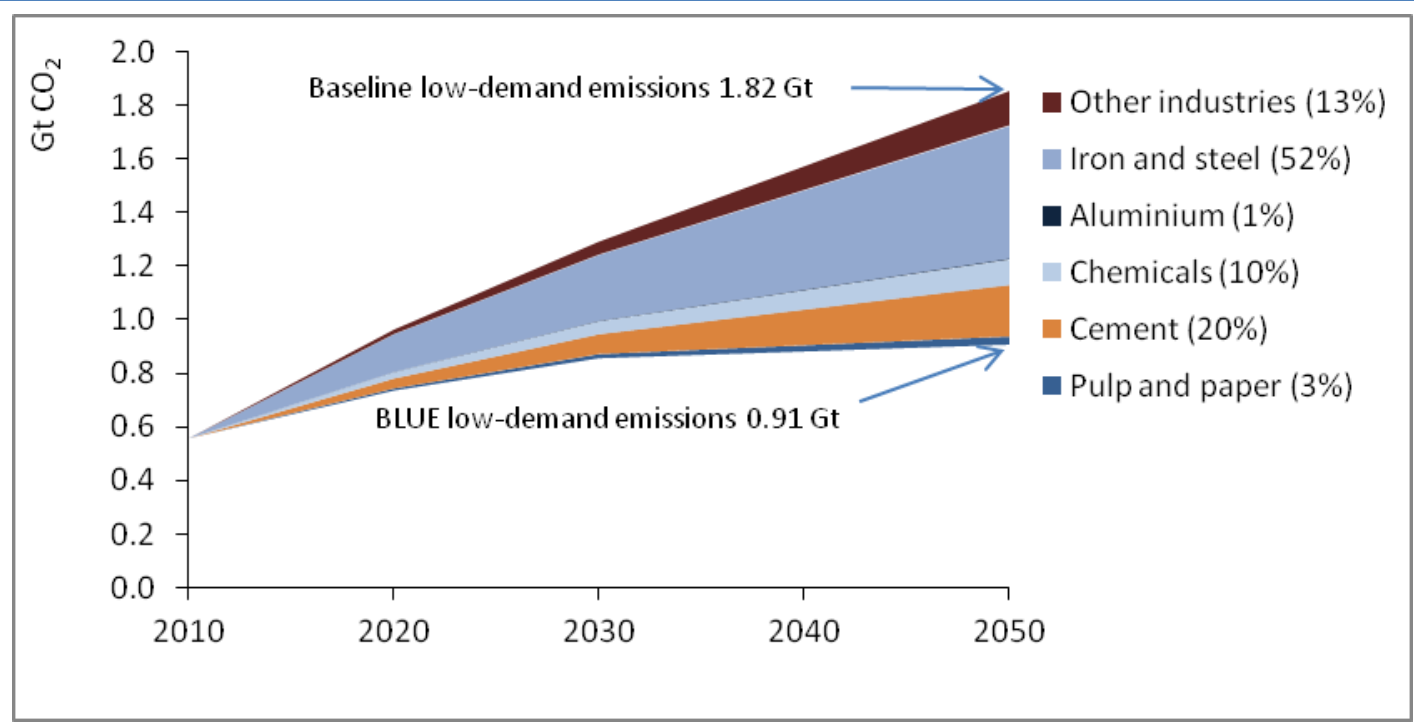

\section{Iron and steel}

India's crude steel production is projected to increase five to ten times between 2007 and 2050, under both the Baseline and BLUE scenarios. Energy consumption also increases but at a slower pace (Table ES.2). Several options exist in the iron and steel sector to reduce the level of energy use and associated $\mathrm{CO}_{2}$ emissions. In the BLUE Scenario, energy consumption in 2050 is about $28 \%$ lower than in the Baseline Scenario. Direct $\mathrm{CO}_{2}$ emissions in 2050 in the BLUE Scenario would be twice as high than in 2007, but about 50\% lower than in the Baseline Scenario.

Table ES.2: Production, energy consumption and $\mathrm{CO}_{2}$ emissions for India's iron and steel industry

\begin{tabular}{|l|c|c|c|c|c|c|c|}
\hline & 2007 & \multicolumn{3}{|c|}{ Baseline-2050 } & \multicolumn{3}{c|}{ BLUE - 2050 } \\
\hline & & $\begin{array}{c}\text { low- } \\
\text { demand }\end{array}$ & $\begin{array}{c}\text { high- } \\
\text { demand }\end{array}$ & $\begin{array}{c}\text { strong } \\
\text { growth }\end{array}$ & $\begin{array}{c}\text { low- } \\
\text { demand }\end{array}$ & $\begin{array}{c}\text { high- } \\
\text { demand }\end{array}$ & $\begin{array}{c}\text { strong } \\
\text { growth }\end{array}$ \\
\hline Cement production (Mt) & 53 & 266 & 355 & 550 & 266 & 355 & 550 \\
\hline $\begin{array}{l}\text { Energy consumption } \\
\text { (Mtoe) }\end{array}$ & 38 & 173 & 211 & 286 & 122 & 153 & 209 \\
\hline $\begin{array}{l}\text { Direct } \mathrm{CO}_{2} \text { emissions } \\
\left(\mathrm{Mt} \mathrm{CO} \mathrm{C}_{2}\right)\end{array}$ & 151 & 703 & 858 & 1153 & 333 & 362 & 532 \\
\hline
\end{tabular}

The results of the BLUE Scenario are based on the pursuit of four main technical options:

- Improving energy efficiency through the deployment of existing best available technologies (BATs) and the development of new technologies;

- Fuel switching through gas-based direct reduced iron (DRI), reducing coal-based DRI production, using $\mathrm{CO}_{2}$-free electricity and hydrogen;

- Improving the materials flow management (high recycling rates); and

- Providing carbon capture and storage (CCS). 


\section{Cement}

Demand for cement in India will be between 3.8 and 9.7 times higher in 2050 than it was in 2007. Production is projected to be the same under the Baseline and BLUE scenarios (Table ES.3).

Table ES.3: Production, energy consumption and $\mathrm{CO}_{2}$ emissions for India's cement industry

\begin{tabular}{|l|c|c|c|c|c|c|c|}
\hline & $\mathbf{2 0 0 7}$ & \multicolumn{3}{|c|}{ Baseline - 2050 } & \multicolumn{3}{c|}{ BLUE - 2050 } \\
\hline & & $\begin{array}{c}\text { low- } \\
\text { demand }\end{array}$ & $\begin{array}{c}\text { high- } \\
\text { demand }\end{array}$ & $\begin{array}{c}\text { strong } \\
\text { growth }\end{array}$ & $\begin{array}{c}\text { low- } \\
\text { demand }\end{array}$ & $\begin{array}{c}\text { high- } \\
\text { demand }\end{array}$ & $\begin{array}{c}\text { strong } \\
\text { growth }\end{array}$ \\
\hline Cement production (Mt) & 170 & 646 & 742 & 1656 & 646 & 742 & 1656 \\
\hline $\begin{array}{l}\text { Energy consumption } \\
\text { (Mtoe) }\end{array}$ & 13 & 42 & 48 & 105 & 48 & 55 & 126 \\
\hline $\begin{array}{l}\text { Direct } \mathrm{CO}_{2} \text { emissions } \\
\left(\mathrm{Mt} \mathrm{CO}_{2}\right)\end{array}$ & 128 & 422 & 483 & 1060 & 275 & 291 & 676 \\
\hline
\end{tabular}

Based on the technology characteristics of India's cement industry, it appears clear that the efficiency of India's cement production is better than the world average. The majority of large kilns are among the most energy efficient in the world. As such, little improvement can be achieved by applying BATs in these large kilns, but there is large potential to improve efficiency if BAT is applied in smaller units. Other measures could deliver large energy and/or $\mathrm{CO}_{2}$ emissions reduction. Those measures include:

- Improving cement production energy efficiency by deploying existing BATs for new plants and small units, and phasing out wet kilns and retrofitting to more energy-efficient technologies;

- Expanding the use of clinker substitutes;

- Fuel switching to less carbon-intensive fossil fuels, and expanding the use of biomass and alterative fuels; and

- Providing CCS.

\section{Chemicals and petrochemicals}

India's chemical and petrochemical sector continues to be very innovative, but is it unclear how it will develop in future if, for example, substantially higher oil and gas prices slow demand. Even though the pace is expected to slow to some extent, the sector is still expected to grow significantly in the coming decades, both in India and globally.

A growing world population is likely to require more fertilisers to produce food and to meet increased demand for biomass as a fuel and a feedstock. In the last few decades, the sector has experienced substantial growth world wide. The production of high-valued chemicals (HVC) ${ }^{1}$ in India is projected to be between 4.3 and 10 times higher in 2050 than in 2007. Ammonia and methanol production will also increase substantially (Table ES.4).

\footnotetext{
${ }^{1}$ High-value chemicals include ethylene, propylene from the pyrolysis gas of steam crackers, benzene (contained amounts, excluding extracted amounts), butadiene (also contained), acetylene and hydrogen (sold as fuel).
} 
Table ES.4: Production, energy consumption and $\mathrm{CO}_{2}$ emissions for India's chemical and petrochemical industry

\begin{tabular}{|l|r|r|r|r|r|r|r|}
\hline & 2007 & \multicolumn{3}{|c|}{ Baseline - 2050 } & \multicolumn{2}{c|}{ BLUE - 2050 } \\
\hline & & \multicolumn{1}{|c|}{$\begin{array}{c}\text { low- } \\
\text { demand }\end{array}$} & $\begin{array}{c}\text { high- } \\
\text { demand }\end{array}$ & $\begin{array}{c}\text { strong } \\
\text { growth }\end{array}$ & $\begin{array}{c}\text { low- } \\
\text { demand }\end{array}$ & $\begin{array}{c}\text { high- } \\
\text { demand }\end{array}$ & $\begin{array}{c}\text { strong } \\
\text { growth }\end{array}$ \\
\hline Production (Mt) & & & & & & & \\
\hline- High-value chemicals & 10 & 45 & 80 & 104 & 39 & 39 & 91 \\
\hline- Ammonia & 13 & 30 & 33 & 47 & 30 & 43 \\
\hline- Methanol & 0.1 & 0.8 & 1.0 & 1.4 & 0.8 & 1.0 & 1.4 \\
\hline $\begin{array}{l}\text { Total energy } \\
\text { consumption (Mtoe) }\end{array}$ & 27 & 83 & 126 & 165 & 74 & 100 & 153 \\
\hline $\begin{array}{l}\text { Total direct } \mathrm{CO}_{2} \\
\text { emissions (Mt } \mathrm{CO}_{2} \text { ) }\end{array}$ & 48 & 132 & 173 & 229 & 68 & 77 & 119 \\
\hline
\end{tabular}

If the expected substantial growth in the chemical and petrochemical sector is to be sustainable and consistent with achieving broader goals for $\mathrm{CO}_{2}$ emissions reduction, steps will need to be taken, notably on:

- Implementing best practice technologies (BPT) in the short term and new technologies in the long term;

- Expanding the production of bio-based plastics and chemicals, and continuing to switch away from oil feedstock;

- Improving the flow management of materials; and

- Providing CCS.

\section{Pulp and paper}

Demand for paper and paperboard in India is expected to increase from 7.7 kilogram per capita (kg/cap) today to $43 \mathrm{~kg} / \mathrm{cap}$ in the low-demand case, $76 \mathrm{~kg} / \mathrm{cap}$ in the high-demand case and $120 \mathrm{~kg} / \mathrm{cap}$ in the strong growth case. These strong increases in demand will drive the production of paper and paperboard in India from 7.6 Mt in 2007 to between $81 \mathrm{Mt}$ and $232 \mathrm{Mt}$ in 2050. Despite this strong increase in production, the energy consumption associated with the production of pulp and paper will only be 6.1 to 15 times higher in the BLUE Scenario in 2050 than in 2007 (Table ES.5).

Table ES.5: Production, energy consumption and $\mathrm{CO}_{2}$ emissions for India's pulp and paper industry

\begin{tabular}{|l|c|c|c|c|c|c|c|}
\hline & 2007 & \multicolumn{3}{|c|}{ Baseline - 2050 } & \multicolumn{3}{c|}{ BLUE - 2050 } \\
\hline & & $\begin{array}{c}\text { low- } \\
\text { demand }\end{array}$ & $\begin{array}{c}\text { high- } \\
\text { demand }\end{array}$ & $\begin{array}{c}\text { strong } \\
\text { growth }\end{array}$ & $\begin{array}{c}\text { low- } \\
\text { demand }\end{array}$ & $\begin{array}{c}\text { high- } \\
\text { demand }\end{array}$ & $\begin{array}{c}\text { strong } \\
\text { growth }\end{array}$ \\
\hline Production (Mt) & & & & & & & 19 \\
\hline- Pulp & 4 & 13 & 21 & 19 & 11 & 16 \\
\hline- Paper and paperboard & 8 & 81 & 148 & 232 & 81 & 148 & 232 \\
\hline $\begin{array}{l}\text { Total energy } \\
\text { consumption (Mtoe) }\end{array}$ & 3 & 19 & 33 & 47 & 17 & 31 & 43 \\
\hline $\begin{array}{l}\text { Total direct } \mathrm{CO}_{2} \\
\left.\text { emissions (Mt } \mathrm{CO}_{2}\right)\end{array}$ & 8 & 36 & 62 & 87 & 17 & 32 & 50 \\
\hline
\end{tabular}


The following options are available to limit the growth in energy use and associated $\mathrm{CO}_{2}$ emissions in the pulp and paper industry:

- Deploying BATs, including black liquor and biomass gasification, increasing waste heat recovery, developing and implementing new paper-drying technologies, and increasing the use of combined heat and power (CHP);

- Fuel switching from fossil fuels to combustible biomass;

- Increasing the use of recovered paper; and

- Providing CCS.

\section{Aluminium}

India is an important player in the aluminium sector, especially because of its abundant bauxite reserves. In 2007, India was the eighth-largest producer of primary aluminium world wide. The strong growth in production between 2007 and 2050 (Table ES.6) will mostly be driven by the growth in aluminium used in transportation, building and power sectors.

Table ES.6: Production, energy consumption and $\mathrm{CO}_{2}$ emissions for India's aluminium industry

\begin{tabular}{|l|c|c|c|c|c|c|c|}
\hline & 2007 & \multicolumn{3}{|c|}{ Baseline - 2050 } & \multicolumn{3}{c|}{ BLUE - 2050 } \\
\hline & & $\begin{array}{c}\text { low- } \\
\text { demand }\end{array}$ & $\begin{array}{c}\text { high- } \\
\text { demand }\end{array}$ & $\begin{array}{c}\text { strong } \\
\text { growth }\end{array}$ & $\begin{array}{c}\text { low- } \\
\text { demand }\end{array}$ & $\begin{array}{c}\text { high- } \\
\text { demand }\end{array}$ & $\begin{array}{c}\text { strong } \\
\text { growth }\end{array}$ \\
\hline $\begin{array}{l}\text { Primary aluminium } \\
\text { production (Mt) }\end{array}$ & 1 & 11 & 17 & 20 & 10 & 16 & 20 \\
\hline $\begin{array}{l}\text { Energy consumption } \\
\text { (Mtoe) }\end{array}$ & 3 & 16 & 25 & 28 & 14 & 20 & 26 \\
\hline $\begin{array}{l}\text { Direct } \mathrm{CO}_{2} \text { emissions } \\
\left(\mathrm{Mt} \mathrm{CO}_{2}\right)\end{array}$ & 4 & 14 & 21 & 22 & 12 & 16 & 22 \\
\hline
\end{tabular}

Data available on the sector suggest that average energy intensity of primary aluminium production in India is currently close to the world average. There is still room to further improve the energy efficiency and reduce $\mathrm{CO}_{2}$ emissions by:

- Implementing energy efficiency measures in both refining and smelting;

- Increasing the use of low-carbon electricity sources;

- Increasing recycling; and

- Introducing new smelting technologies.

\section{Transition to a low-carbon energy future}

A truly global and integrated energy technology revolution is essential to address the intertwined challenges of energy security and climate change while also meeting the growing energy needs of the developing world. For India to play its part in realising the global goals of the BLUE scenario, it will need to achieve rapid economic development over the next 40 years with only a very small increase in $\mathrm{CO}_{2}$ emissions. Currently there is no precedent for such a low- $\mathrm{CO}_{2}$ development path. It will need to be based on meeting the increasing energy needs of India's growing population through the widespread deployment of a range of existing and new low-carbon technologies. 
In the industrial sector, the application of BATs and the development of breakthrough technologies will help in reducing emissions. CCS will be needed to keep the increase in emissions in line with the overall reduction targets. Priority should be given to reducing the $\mathrm{CO}_{2}$ intensity in the three largest industrial sectors (iron and steel, chemicals and petrochemicals and cement). Special attention should focus on coal-based DRI, pulp and paper making and small-scale cement kilns. There three areas offer interesting opportunities to increase efficiency and limit the growth in energy consumption.

The challenge for India will be to achieve a strong economic growth while improving their energy security but without locking in high emissions. In identifying the step towards achieving this, national technology roadmaps for the most promising low-carbon technologies should be developed. It will also require international collaboration on a number of initiatives. Enhanced international co-operation for researching, developing, sharing and transferring technologies will be required. International mechanisms for reducing carbon such as the Clean Development Mechanism (CDM) will need to play a role in deploying low-carbon energy technologies in India. 



\section{Introduction}

The fourth assessment report of the United Nations Intergovernmental Panel on Climate Change (IPCC), released in November 2007, concluded that global carbon dioxide $\left(\mathrm{CO}_{2}\right)$ emissions must be reduced by between $50 \%$ and $85 \%$ by 2050 (compared to 2000 levels) if global warming is to be limited to between $2.0^{\circ} \mathrm{Celsius}\left({ }^{\circ} \mathrm{C}\right)$ and $2.4^{\circ} \mathrm{C}$.

Following the publication of the IPCC report, the urgency to address climate change rose significantly. A general guideline is that global $\mathrm{CO}_{2}$ emissions must be halved.

In 2010, the International Energy Agency (IEA) published Energy Technology Perspectives 2010 (ETP 2010) (IEA, 2010). The book explains how to transform the global energy economy over the coming decades. A BLUE Scenario was developed to explore the energy and technology implications of reducing global energy-related $\mathrm{CO}_{2}$ emissions to $50 \%$ of the 2005 levels by 2050. If fully implemented, the BLUE Scenario could limit the long-term global mean temperature rise to between $2.0^{\circ} \mathrm{C}$ and $3.0^{\circ} \mathrm{C}$. The analysis indicates that beyond 2030 , the end-use sectors (residential, services, industry and transport) have an increasingly important role to play in reducing emissions (Figure 1). Achieving such a significant reduction requires maximum energy efficiency world wide and a virtually decarbonised power sector.

Figure 1: Global $\mathrm{CO}_{2}$ emissions reduction by sector in the BLUE Scenario

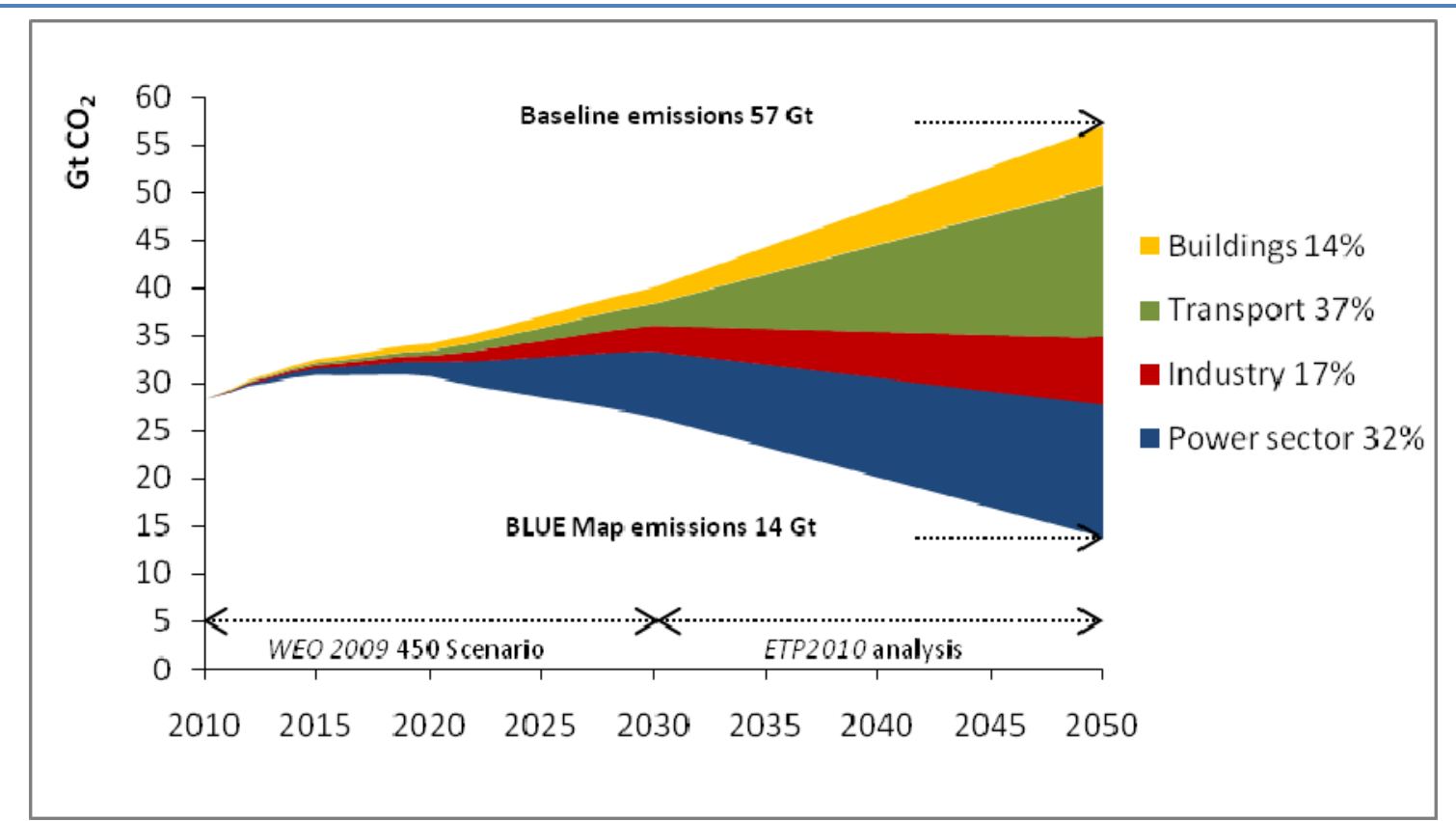

Note: $\mathrm{CO}_{2}$ emissions savings from fuel transformation have been allocated to the transport sector and the reduction in $\mathrm{CO}_{2}$ from electricity savings has been allocated to end-use sector.

Source: IEA, 2010.

To achieve a $50 \%$ reduction in $\mathrm{CO}_{2}$ emissions globally by 2050, ETP 2010 calculated that, based on a "least-cost approach", industry would have to reduce its overall emissions to $24 \%$ of the 2007 levels by 2050. The contribution from different countries and industrial sectors varies according to their respective potential to reduce emissions through energy efficiency, the availability of fuel-switching and recycling options, and their potential for deploying carbon capture and storage (CCS). 
As part of the ETP 2010 analysis, the Baseline and BLUE scenarios presented in the previous ETP report (ETP 2008, IEA, 2008a) have been elaborated to include more information on the following four countries/regions: China, India, OECD Europe ${ }^{2}$ and the United States.

This working paper further develops the analysis presented in the India chapter of ETP 2010 and provides insights on the implications of achieving deep energy and $\mathrm{CO}_{2}$ emission cuts in the Page | 18 industrial sector both for India and globally. It investigates from a Baseline Scenario the leastcost options to significantly reduce energy and $\mathrm{CO}_{2}$ emissions in India's industrial sector, while enabling the Indian economy to continue to grow and alleviate energy poverty. It does so from a techno-economical perspective - building on detailed resource and technology data for India. It also identifies the key technologies for India, as well as the energy and $\mathrm{CO}_{2}$ savings that would result from their deployment. It analyses the possibilities for energy efficiency improvements and $\mathrm{CO}_{2}$ emissions reduction for the five most energy-intensive industrial sectors including: iron and steel; cement; chemicals and petrochemicals; pulp and paper; and aluminium. Each sector presents a review of recent trends based on the latest IEA industry indicators ${ }^{3}$ and an analysis of the potential of existing technologies to increase energy efficiency and reduce $\mathrm{CO}_{2}$ emissions for India and for the world.

The intent is not to examine what kind of energy savings or $\mathrm{CO}_{2}$ emissions reduction India should make in the future or analyse how to achieve the deployment of low-carbon technology in India, or what technology transfer should look like and in which areas it would be needed. However, discussion of generic technology transfer issues is included in ETP 2010.

The paper comprises three chapters:

Chapter 1 provides an overview of the results for the industrial sector both for India and for the world. The results are presented for the two different variants of the industrial sector included in ETP 2010 - the low- and high-demand cases.

Chapter 2 examines the energy and emissions trends by sub-industry, both for India and the global economy. It also provides insights into the future energy technologies that will play a part in reducing emissions for India and at the global level.

Chapter 3 presents an alternative case using stronger growth in gross domestic product (GDP) and materials production for India. The "strong growth" case shows the implication of a strong growth in India assuming the same level of research, development, demonstration and deployment (RDD\&D) and the carbon price is the same as in the BLUE Scenario.

\footnotetext{
${ }^{2}$ OECD Europe includes: Austria, Belgium, Czech Republic, Denmark, Finland, France, Germany, Greece, Hungary, Iceland, Ireland, Italy, Luxembourg, the Netherlands, Norway, Poland, Portugal, Slovak Republic, Spain, Sweden, Switzerland, Turkey and the United Kingdom.

${ }^{3}$ In the context of this publication, an "indicator" is defined as any information that helps to explain an energy situation or a change in energy at the economy, industry, country or global level. Indicators in this paper include: energy intensity; use of a particular technology or feedstock; efficiency improvement; and savings potential.
} 


\section{Chapter 1. Industry overview}

In India, industrial energy use ${ }^{4}$ reached 150 million tonnes of oil equivalent (Mtoe) in 2007 accounting for $38 \%$ of the country's final energy used. From a global perspective, India is the fourth-largest industrial energy consumer with a $5 \%$ share of total industrial energy use, surpassed only by China, the United States and Russia (Figure 2).

Globally, industry accounts for one-third of all the energy used and for almost $40 \%$ of worldwide carbon dioxide $\left(\mathrm{CO}_{2}\right)$ emissions. In 2007, total final energy use in industry amounted to 3019 Mtoe. Direct emissions ${ }^{5}$ of $\mathrm{CO}_{2}$ in industry amounted to 7.6 gigatonnes of $\mathrm{CO}_{2}\left(\mathrm{Gt} \mathrm{CO}_{2}\right)$ and indirect emissions ${ }^{6}$ to $3.9 \mathrm{Gt} \mathrm{CO}_{2}$. Reducing $\mathrm{CO}_{2}$ emissions from industry must be an essential part of a global action to prevent dangerous climate change. The International Energy Agency (IEA) analysis shows that industry will need to reduce its current direct emissions by about $24 \%$ of 2007 levels if it is to halve global emissions from 2005 levels by 2050.

Figure 2: Industrial energy use by region, 2007

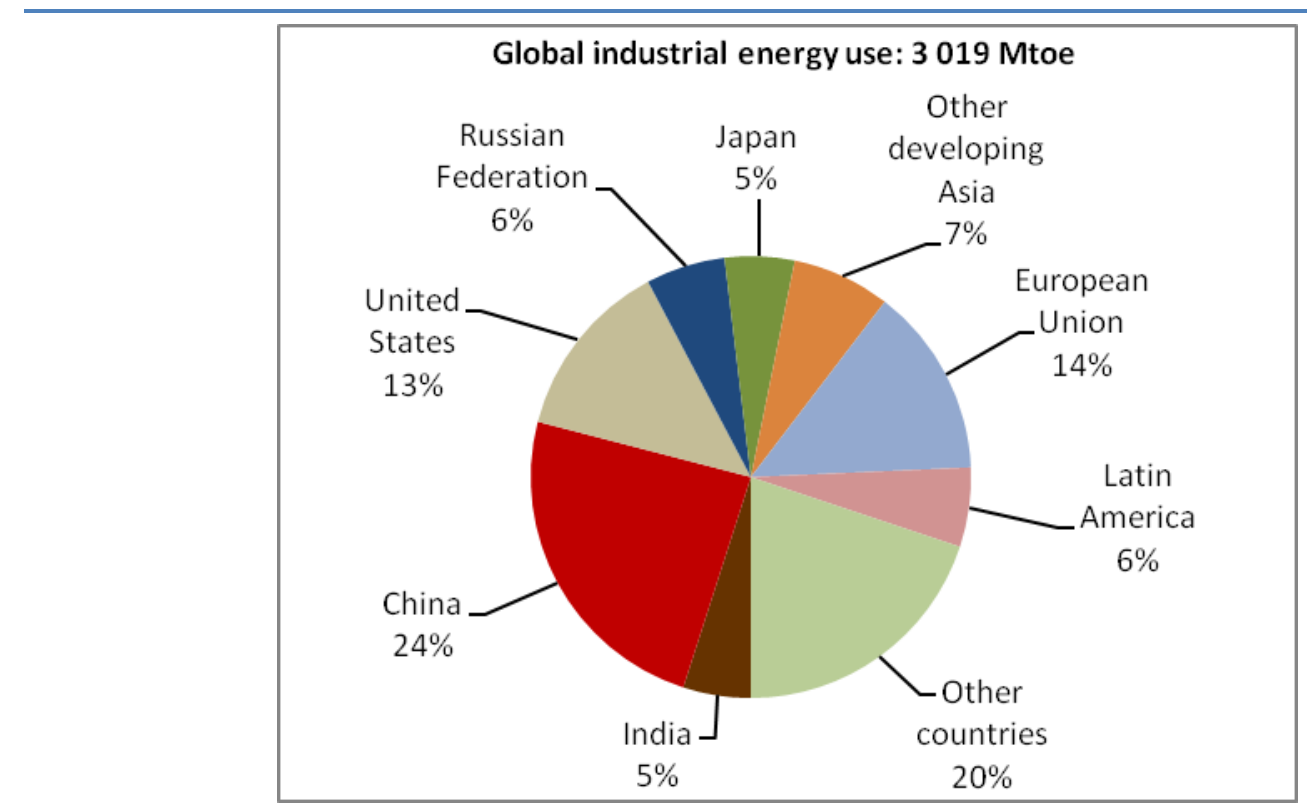

Note: This includes coke ovens, blast furnaces and petrochemical feedstock.

Sources: IEA, 2009b; IEA, 2009c.

The five most energy-intensive industrial sectors (iron and steel, cement, chemicals and petrochemicals, pulp and paper, and aluminium) accounted for $56 \%$ of India's industrial energy consumption in 2007. Globally, these five sectors accounted for $66 \%$ of industrial energy consumption (Figure 3).

\footnotetext{
${ }^{4}$ In this document, iron and steel includes energy use for coke making. The energy data for chemicals and petrochemicals include feedstock.

${ }^{5}$ Direct emissions include fuel combustion and process-related $\mathrm{CO}_{2}$ emissions from within the industry.

${ }^{6}$ Indirect emissions are emissions from the power generation sector due to electricity use in industry.
} 
Figure 3: Industrial final energy consumption by sub-sector in India and in the world, 2007

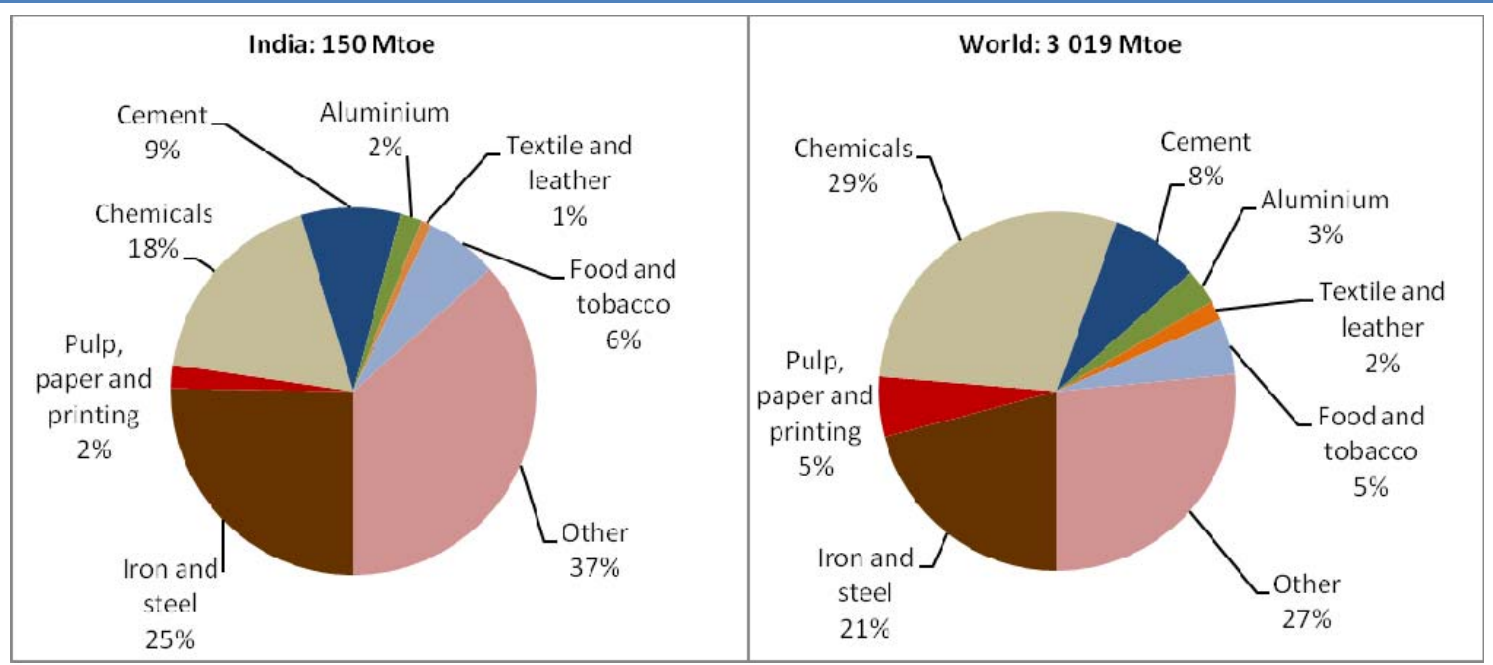

Note: This includes coke ovens, blast furnaces and petrochemical feedstock.

Sources: IEA, 2009b; IEA, 2009c; IEA analysis.

The final energy mix of Indian industry is dominated by coal and oil (Figure 4). The share of biomass use in Indian industry is large compared to other countries. In India, industry consumes about $45 \%$ of all electricity generated in the country. In the industrial sector, electricity accounts for $15 \%$ of energy consumption. About $30 \%$ of the electricity used by industry is generated by captive power plants. ${ }^{7}$

Figure 4: Industrial final energy mix in India and in the world, 2007

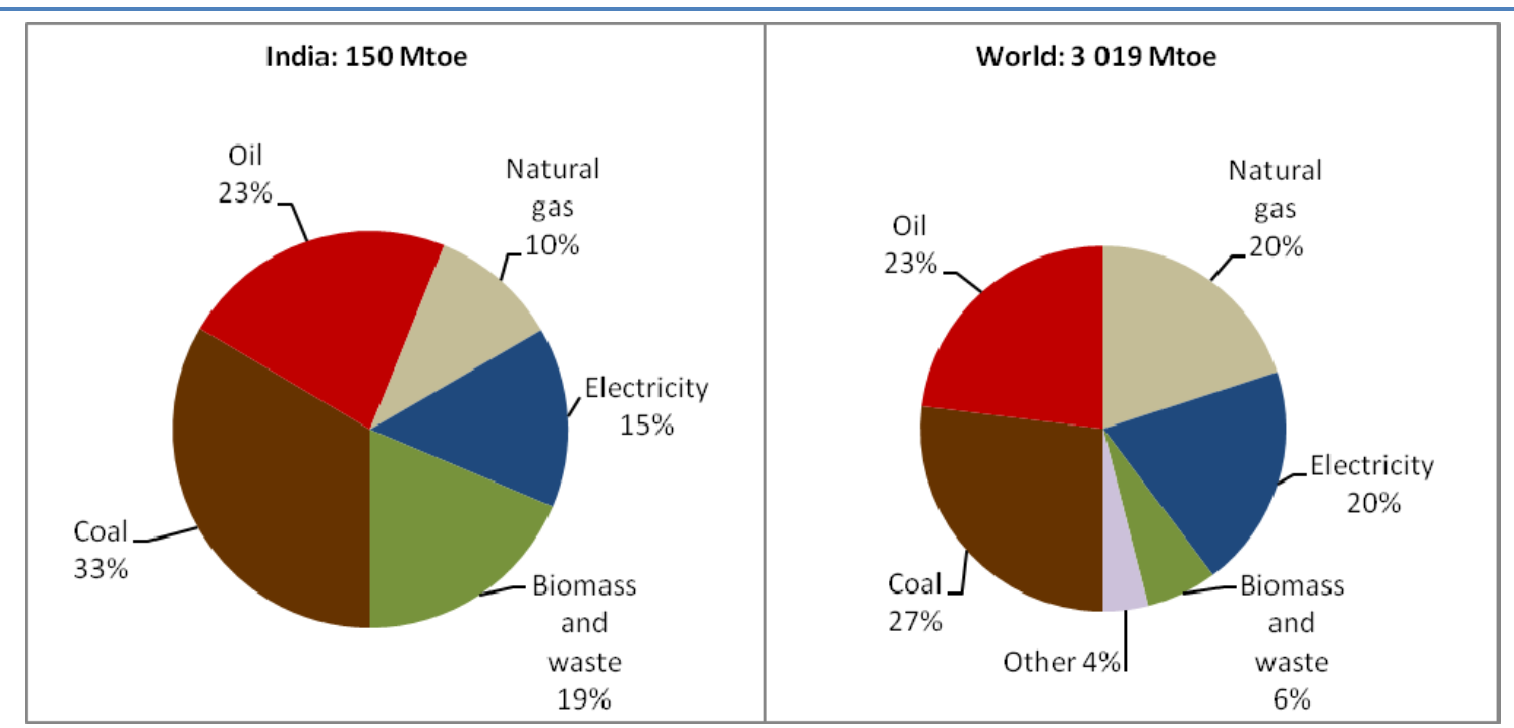

Note: This includes coke ovens, blast furnaces and petrochemical feedstock.

Sources: IEA, 2009b; IEA, 2009c.

An important shortcoming of the data on India's energy use, as reported in the IEA statistics, is that over 22 Mtoe of electricity, 28 Mtoe of biomass and waste, and 7 Mtoe of natural gas consumption are not allocated to particular sub-sectors but are reported under "non-specified industry". Overall, about $43 \%$ of industrial energy use in India is reported under the non-specified

\footnotetext{
${ }^{7}$ Captive stations are units set up by industrial plants for their exclusive supply.
} 
category (Table 1). Furthermore, the statistics for biomass consumption are highly uncertain. As a consequence, it is not possible to perform detailed energy efficiency analyses for the industry as a whole based on these data. The IEA has developed estimates of India's energy consumption by compiling a mixture of top-down and bottom-up sources. The energy use as reported in IEA statistics (IEA, 2009c) as well as the estimates used in the current analysis are presented in Table 1. These estimates are based on current production levels and energy intensities from a range of sources. There is still a need to validate these data.

Table 1: India's industrial materials production and energy use, 2007

\begin{tabular}{|c|c|c|c|c|c|c|}
\hline & Production & $\begin{array}{l}\text { Reported } \\
\text { energy use }\end{array}$ & $\begin{array}{c}\text { Reported } \\
\text { electricity use }\end{array}$ & $\begin{array}{l}\text { Estimated } \\
\text { energy use }\end{array}$ & $\begin{array}{l}\text { Estimated } \\
\text { electricity use }\end{array}$ & $\begin{array}{l}\text { Estimated } \\
\text { direct } \mathrm{CO}_{2} \\
\text { emissions }\end{array}$ \\
\hline & (Mt) & (Mtoe) & (Mtoe) & (Mtoe) & (Mtoe) & $(\mathrm{Mt} \mathrm{CO} 2)$ \\
\hline Industry sector & & 150 & 22 & 150 & 22 & 413 \\
\hline Iron and steel & 53 & 33 & & 38 & 3.3 & 151 \\
\hline $\begin{array}{l}\text { Chemicals and } \\
\text { petrochemicals }\end{array}$ & & 27 & & 27 & & 48 \\
\hline Non-ferrous metals & & 0.4 & & & & \\
\hline Total aluminium & 2 & - & - & 2.9 & 1.6 & 3.8 \\
\hline Non-metallic minerals & & 11 & & & & \\
\hline Cement & 170 & - & - & 13 & 1.1 & 128 \\
\hline $\begin{array}{l}\text { Pulp, paper and } \\
\text { printing }\end{array}$ & & 1.4 & & & & 8.2 \\
\hline $\begin{array}{l}\text { Paper and } \\
\text { paperboard }\end{array}$ & 8 & - & - & 1.4 & 0.4 & \\
\hline Pulp & 4 & - & - & 1.7 & 0.3 & \\
\hline Recovered paper & 1 & - & - & 0.1 & 0.0 & \\
\hline Food and tobacco & & 10 & & n.a. & n.a. & n.a. \\
\hline Textile and leather & & 1.3 & & n.a. & n.a. & n.a. \\
\hline Other & & 2 & & 66 & 15 & 74 \\
\hline Non-specified industry & & 65 & 22 & & & \\
\hline
\end{tabular}

Notes: Iron and steel includes energy use for coke making and the energy data for chemicals and petrochemicals include feedstock. The table has been compiled from a mixture of top-down and bottom-up sources and so the totals may not match.

Sources: Worldsteel, 2009; USGS, 2009a; IAI, 2009a; IPMA ,2010a; IEA, 2009a, b, c; IEA analysis.

\section{Energy and $\mathrm{CO}_{2}$ savings potential in India, based on best available technologies ${ }^{8}$}

In order to quantify the energy and $\mathrm{CO}_{2}$ savings potential by applying best available technologies (BATs), the IEA developed a top-down approach. In this approach the theoretical minimum energy consumption is calculated by assuming each process in a sector would apply BAT (or best practice technology [BPT] in the case of the chemical and petrochemical sector). In order to assess the potential reduction in energy and $\mathrm{CO}_{2}$ emissions, the estimated energy consumption values are compared to the reported actual energy consumption.

\footnotetext{
${ }^{8}$ Defining best available technology (BAT) requires consideration of both technical and economic factors. In the IEA's analysis, BAT designation in relation to energy efficiency in a particular industry has been drawn from a range of sources, including technical documentation produced for the European Union Directive 96/61/EC concerning integrated pollution prevention and control, and other technical and peer reviewed literature. In contrast to BAT, BPT is a term that applies to technologies and processes that are currently deployed. BAT could, in many cases, be identical to BPT. In other cases, a new technology may have just emerged but is not yet deployed. If this is the case, the BAT energy efficiency may be better than BPT.
} 
As is the case in most countries, significant energy and $\mathrm{CO}_{2}$ savings in Indian industry are possible when BATs are implemented. It is estimated that applying BATs in the five industrial sectors analysed (iron and steel, pulp and paper, chemicals and petrochemicals, cement and aluminium) could reduce India's final energy use by between $10 \%$ and $25 \%$. Total estimated savings in India could amount to 17 Mtoe per year, which is equivalent to $11 \%$ of the industrial energy consumption in 2007 and $4 \%$ of India's total energy consumption.

The BAT analysis does not take into account the potential improvements in energy efficiency from industrial captive power plants. It is important to analyse the energy efficiency potential of those captive plants to assess the overall reduction potential. However, the peculiarities of India's indigenous resources and industry, such as the high silica content in iron ore, low-quality coal and the existence of numerous small-scale plants, means that these savings might be harder to achieve and may be overstated. Furthermore, it will not be possible to achieve these savings immediately. The rate of implementing BATs in practice depends on a number of factors, including capital stock turnover, relative energy costs, raw material availability, rates of return on investment and regulation.

\section{IEA scenarios for India's industrial sector}

Worldwide implementation of BATs is just the first step in improving energy efficiency and making deep cuts in $\mathrm{CO}_{2}$ emissions in industry. A detailed modelling framework is used to analyse the long-term potential for new technologies to improve energy efficiency and reduce $\mathrm{CO}_{2}$ emissions and to examine different scenarios to the year 2050.

If India follows a traditional growth model with a transition from an agricultural society to a highly urbanised society, the need for materials will be enormous. This is reflected in the demand projections for 2030 and 2050 (Table 2) and raises questions regarding the availability of resources.

Table 2: India's materials demand in kilograms per capita (kg/cap)

\begin{tabular}{|c|c|c|c|c|c|}
\hline & \multirow[t]{2}{*}{2007} & \multicolumn{2}{|c|}{2030} & \multicolumn{2}{|c|}{2050} \\
\hline & & low-demand & high-demand & low-demand & high-demand \\
\hline Primary aluminium & 0.9 & 3.5 & 5.9 & 6.3 & 8.8 \\
\hline Cement & 151 & 325 & 364 & 400 & 460 \\
\hline \multicolumn{6}{|c|}{ Chemicals and petrochemicals } \\
\hline HVC & 9 & 17 & 27 & 28 & 50 \\
\hline Methanol & 0.1 & 0.4 & 0.4 & 0.6 & 0.7 \\
\hline Ammonia & 12 & 16 & 19 & 19 & 23 \\
\hline Iron and steel & 49 & 150 & 175 & 200 & 250 \\
\hline Paper and paperboard & 8 & 23 & 39 & 43 & 76 \\
\hline
\end{tabular}

Industrial materials production, energy use and $\mathrm{CO}_{2}$ emissions are all projected to rise. As the production of materials increases, industrial energy consumption is expected to reach between 524 Mtoe and 634 Mtoe in 2050 under the Baseline Scenario (Table 3). 
Table 3: India's total final energy use by industry, Mtoe

\begin{tabular}{|c|c|c|c|c|c|}
\hline & \multirow[t]{2}{*}{2007} & \multicolumn{2}{|c|}{ Baseline - 2050} & \multicolumn{2}{|c|}{ BLUE - 2050} \\
\hline & & low-demand & high-demand & low-demand & high-demand \\
\hline Aluminium & 3 & 16 & 25 & 14 & 20 \\
\hline Cement & 13 & 42 & 48 & 49 & 55 \\
\hline Chemicals and petrochemicals & 27 & 83 & 126 & 74 & 100 \\
\hline Iron and steel & 38 & 173 & 211 & 122 & 153 \\
\hline Pulp and paper & 3 & 19 & 33 & 17 & 31 \\
\hline Other industries & 66 & 191 & 191 & 126 & 134 \\
\hline Total & 150 & 524 & 634 & 402 & 624 \\
\hline
\end{tabular}

Sources: IEA, 2009c; IEA analysis.

The Baseline Scenario considers all policies implemented to date. A BLUE Scenario, in which global industrial energy-related emissions would be $24 \%$ lower by 2050 compared to 2007 levels, has been investigated with maximum use of energy efficiency, high levels of recycling, greater shares of biomass use and the implementation of carbon capture and storage (CCS) in the iron and steel, cement, chemical, and pulp and paper sectors. In the BLUE Scenario for India, final energy use is approximately $22 \%$ lower than in the Baseline Scenario, but still between 2.7 and 3.3 times higher than the 2007 level. Because the production growth far exceeds the savings potential from energy efficiency and other reduction options, in all scenarios the final energy use in 2030 and 2050 will be significantly higher than today.

Box 1: The ETP 2010 scenarios

The ETP 2010 Baseline Scenario follows the Reference Scenario, outlined in the World Energy Outlook 2009, to 2030, and then extends it to 2050. The Baseline Scenario assumes that governments will not introduce new energy and climate policies. In contrast, the BLUE Scenario (with several variants) is target-orientated: it sets the goal of halving global energy-related $\mathrm{CO}_{2}$ emissions by 2050 (compared to 2005 levels). It examines the least-cost means of achieving that goal through the deployment of existing and new low-carbon technologies.

These scenarios are not predictions. They are internally consistent analyses of the least-cost pathways that may be available to meet energy policy objectives, given a certain set of optimistic technology assumptions.

For the industry sector, given the recent global economic crisis and uncertainties about projecting long-term growth in consumption of materials, a low-demand and a high-demand case have been developed for each industry and for all countries analysed. In the five sectors covered in this analysis, the difference in materials demand between the low- and high-demand cases to 2050 varies by between $20 \%$ and $50 \%$. As both the BLUE low- and high-demand scenarios aim to achieve the same level of $\mathrm{CO}_{2}$ emissions in 2050, a greater reduction in emissions levels is needed in the high-demand case than in the low-demand one. As a result, costs are also higher in the high-demand case.

The industrial scenarios take an optimistic view of technology development and assume that technologies are adopted as they become cost-competitive. The analysis does not assess the likelihood of these assumptions being fulfilled. But it is clear that deep cuts in $\mathrm{CO}_{2}$ emissions can only be achieved if all countries play their part, both in seeking to achieve that outcome and in developing and deploying the technologies that can help to bring it about.

In the Baseline Scenario for India, total direct industrial $\mathrm{CO}_{2}$ emissions are projected to rise from 413 million tonnes of $\mathrm{CO}_{2}\left(\mathrm{Mt} \mathrm{CO}_{2}\right)$ in 2007 to between $1568 \mathrm{Mt} \mathrm{CO}$ and $1852 \mathrm{Mt} \mathrm{CO} 2$ in 2050 (Table 4). In the BLUE Scenario, total industrial $\mathrm{CO}_{2}$ emissions rise by a much lower rate to 
between $828 \mathrm{Mt} \mathrm{CO}_{2}$ and $800 \mathrm{Mt} \mathrm{CO}_{2}$ in 2050 . Although emissions in the BLUE Scenario are $47 \%$ to $51 \%$ lower than under the Baseline Scenario, they still represent an increase of $100 \%$ to $120 \%$ compared to current levels.

Clearly apart from energy efficiency, other measures will be needed to limit the further growth in Indian energy consumption and $\mathrm{CO}_{2}$ emissions, such as fuel and feedstock switching and greater Page | 24 use of recycled materials. These measures can also help to reduce the rapidly rising dependence on oil and gas.

Table 4: India's direct $\mathrm{CO}_{2}$ emissions by industry, $\mathrm{Mt} \mathrm{CO}_{2}$

\begin{tabular}{lrrrrr}
\hline & 2007 & \multicolumn{2}{c}{ Baseline $-\mathbf{2 0 5 0}$} & \multicolumn{2}{c}{ BLUE - 2050 } \\
\hline & & low-demand & high-demand & low-demand & high-demand \\
Aluminium & 4 & 14 & 21 & 12 & 16 \\
Cement & 128 & 422 & 483 & 275 & 291 \\
Chemicals and petrochemicals & 48 & 132 & 173 & 38 & 77 \\
Iron and steel & 151 & 703 & 858 & 17 & 362 \\
Pulp and paper & 8 & 36 & 62 & 122 & 31 \\
Other industries & 74 & 256 & 256 & 828 & 906 \\
\hline Total & 413 & 1563 & 1852 & & 129 \\
\hline
\end{tabular}

Source: IEA, 2009e; IEA analysis.

\section{Material demand projections for industry}

Global growth in industrial production since 1990 has been dominated by China, India and other developing Asia. Together, these countries accounted for over $80 \%$ of the increase in industrial production over this period. The IEA scenario analysis assumes that in the next 20 years, as industrial development matures, there will be another significant change in industrial production growth (Figure 5). In India, other developing Asia, and Africa and the Middle East, industrial development will accelerate as these economies mature.

Figure 5: Materials production by region in the low- and high-demand cases

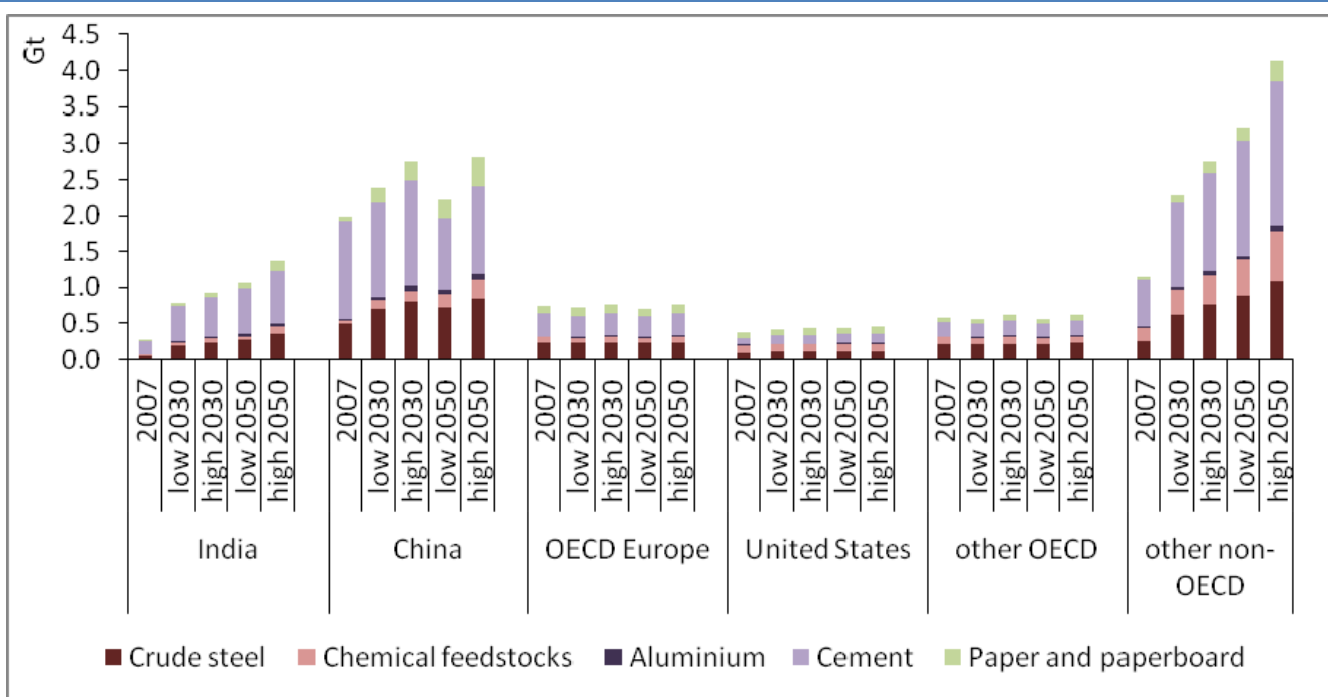

Note: Production of materials is the same for both the Baseline and BLUE scenarios.

Sources: Worldsteel, 2009; USGS, 2009a; IAI, 2009a; IPMA, 2010a; IEA, 2009a; IEA analysis. 
Production in China will flatten or, as in cement production, decline. India's production of the five key materials covered in this analysis is expected, in the low-demand case, to be three times higher than the 2007 levels by 2030 and more than four times higher by 2050. In the high-demand case, production is more than three times higher by 2030 and five times higher by 2050 .

\section{Further considerations}

The energy efficiency of Indian industry varies widely. Certain sectors and companies are among world leaders in terms of efficiency, such as large-scale cement kilns and certain ammonia producers. In sectors where there has been a significant increase in production, the capital stock is newer and often plants are larger, which makes installation of energy efficiency equipment often more cost-effective. In other cases, the efficiency is clearly below world average.

The three largest industrial sectors, (iron and steel, chemicals and petrochemicals, and cement) are responsible for over $25 \%$ of India's overall $\mathrm{CO}_{2}$ emissions and priority should be given to reducing the $\mathrm{CO}_{2}$ intensity in these sectors. Special attention should also focus on coal-based direct reduced iron (DRI), the pulp and paper-making process and small-scale cement kilns. These three areas offer interesting opportunities to increase efficiency and limit the growth in energy consumption. With international support, these industries offer attractive opportunities for the early demonstration of CCS. Broader implementation of sectoral crediting mechanisms could ensure that low-carbon technologies are also used more widely, which in turn would encourage Indian industries to invest in these technologies. India is taking a step in the right direction by introducing its Perform, Achieve and Trade Scheme - a market-based mechanism that improves energy efficiency in energy-intensive large industries and facilities more cost effective by certifying energy savings that could be traded.

Industrial electricity use deserves special attention as it represents $45 \%$ of India's total electricity consumption and the efficiency of power generation is currently low. Industry captive power plants may provide significant potential for improving energy efficiency.

Available feedstock has a number of negative effects on the level of efficiency in Indian industry. Indian coal has a high ash content, which reduces energy efficiency. Small-scale cement kilns have been built in order to exploit small limestone deposits that could not support large kilns. The lack of accessible or available large forest areas that can support large plants largely explains the small scale of India's pulp and paper plants. These disadvantages are structural and the only alternative would be to import materials from other countries, which is often a challenge because of the constraints in transportation infrastructure.

Data collection in India needs to be improved. It is not possible to carry out an accurate analysis of energy efficiency and potential savings, as nearly half of industrial energy use is reported in the unspecified industrial category. The fact that no detailed national comprehensive energy statistics exist poses a major constraint and hinders efficient and effective energy policies. Ideally, one single entity should be nominated to develop an energy balance on an annual basis.

The rapid growth in materials demand in India over the next decades is expected to replicate the growth seen in China over the last decade. Such an increase will have a global impact on both resources and $\mathrm{CO}_{2}$ emissions. Given the projected rapid expansion of India's industrial production, it is of key importance that new investments are based on BAT. Policies are needed to promote the adoption of current BAT and other options such as fuel switching, higher levels of recycling and CCS will need to be deployed to improve energy efficiency and reduce the $\mathrm{CO}_{2}$ intensity of industrial production. 



\section{Chapter 2. Sectoral analysis}

\section{Iron and steel}

\section{Overview and context}

India's iron and steel sector is the largest industrial user of energy in India, consuming 38 million tonnes of oil equivalent (Mtoe) in 2007. It is also the largest industrial source of carbon dioxide $\left(\mathrm{CO}_{2}\right)$ emissions with 151 million tonnes of $\mathrm{CO}_{2}\left(\mathrm{Mt} \mathrm{CO}_{2}\right)$. Indian steel production amounted to 53 million tonnes (Mt) in 2007, an increase of over $10 \%$ per year since 2000 , and accounted for $4 \%$ of the global crude steel production.

The Indian iron and steel industry is unique because of the high share of steel production that relies on feeding direct reduced iron (DRI; also called "sponge iron") into electric furnaces. In 2007, about $29 \mathrm{Mt}$ of Indian steel was produced from ore and $18 \mathrm{Mt}$ from DRI. India is the largest DRI producer in the world and one of only a few countries to produce DRI based on coal.

The product and process mix in the iron and steel industry can have a significant impact on its energy efficiency performance. The feedstock quality (coal and ore quality) can also affect the efficiency markedly. In the case of India, most local coal is not suited for coke making, but it can be used for DRI production. So the choice for the less efficient DRI route was a direct consequence of low-quality resources and the lack of scrap resources.

The amount of scrap available is particularly limited in India. However, as opposed to the situation observed globally, the share of scrap to produce crude steel increased in India from $8 \%$ in 2000 to $18 \%$ in 2007; the world average was $33 \%$ in 2007 . Producing steel from raw materials is much more energy-intensive than producing it from steel scrap. The low amount of steel produced from scrap in India explains the relatively high-energy intensity of Indian steel making.

Table 5: Global steel production, 2007

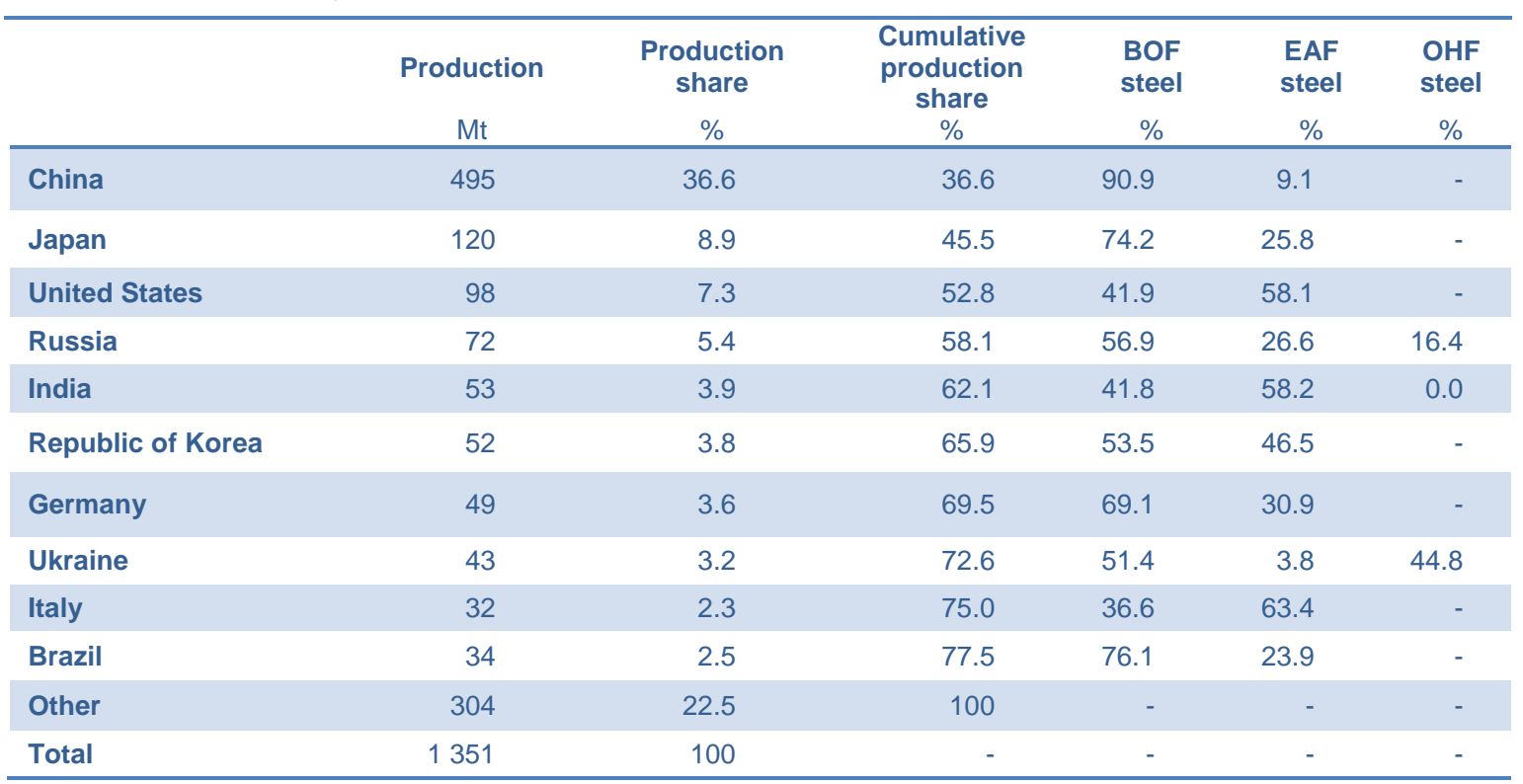

Note: $\mathrm{BOF}=$ basic oxygen furnace; $\mathrm{EAF}=$ Electric arc furnace; and OHF = Open-hearth furnace. EAF steel includes both the scrap/EAF and DRI/EAF routes.

Source: Worldsteel, 2009. 
Globally, the iron and steel sector is the second-largest industrial user of energy, consuming 616 Mtoe in 2007, and the largest industrial source of $\mathrm{CO}_{2}$ emissions with 2.3 gigatonnes of $\mathrm{CO}_{2}$ $\left(\mathrm{Gt} \mathrm{CO}_{2}\right.$ ). World crude steel production amounted to $1351 \mathrm{Mt}$ in 2007 (Worldsteel, 2009). The five most important producers (China, Japan, the United States, Russia and India) account for over $60 \%$ of total world crude steel production (Table 5 ).

Page | 28 While global steel production was nearly constant between 1975 and 2000, it grew by 59\% between 2000 and 2007. The rapid expansion of production capacity has generally had a positive effect on the energy efficiency of the industry. Additional capacity has reduced the average age of the capital stock. New plants tend to be more energy-efficient than old plants, although not all new plants apply the BAT. In addition, energy efficiency equipment has been retrofitted to existing furnaces and ambitious efficiency policies have led to the early closure of inefficient plants in several countries.

But in parallel, recycling as a proportion of total steel production has declined from $47 \%$ in 2000 to around $33 \%$ in 2007 . This decline in scrap use is primarily attributable to the rapid increase in China of using blast furnace/basic oxygen furnace (BF/BOF) technologies, rather than scrap-intensive electric arc furnaces (EAF), as well as the increasing amount of steel in products still in use.

With a limited amount of scrap available, more crude steel has had to be produced from ore to meet the rapid rise in demand for steel. In 2007, about $950 \mathrm{Mt}$ of steel was produced from ore and $65 \mathrm{Mt}$ from DRI. The rise in the global production of primary materials has resulted in higher energy use per tonne of steel products.

\section{Technology and energy consumption in the iron and steel sector}

Steel is produced through a dozen or so processing steps, laid out in various configurations depending on product mix, available raw materials and scrap, energy supply and investment capital. There are three principal modern processing routes:

- BF/BOF, based on $70 \%$ to $100 \%$ ore and the remainder scrap for the iron input.

- Scrap/EAF method based on scrap for the iron input.

- DRI/EAF method based on iron ore and often scrap for the iron input.

Within these processes, the iron and steel industry has complex flows of energy and materials. Most of the commodities can be sold "over the fence" and some can be shipped long distances. As a consequence, energy use and $\mathrm{CO}_{2}$ emissions across the full production chain may be considerably higher or lower than the site footprint would suggest.

A broad-based comparison of total sub-sector energy consumption per tonne of crude steel is of limited use because the production processes are very different. At the very least, the BF/BOF, scrap/EAF and DRI processes need to be treated separately. Even then, there are considerable differences in the energy efficiency of primary steel production among countries and even among individual plants. These differences can be explained by factors such as: economies of scale; the level of waste-energy recovery; the quality of iron ore; operations know-how; and quality control.

Given these and additional complicating factors it was decided not to develop a single measure of efficiency in the iron and steel sector but to develop efficiency and explanatory indicators for individual process steps. Two examples are discussed below: coke dry quenching (CDQ) and the use of reducing agents.

The CDQ process quenches carbonised coke using an inert gas. The heat in the gas is used to generate electricity. Therefore CDQ has energy benefits compared to conventional wet quenching. However, the energy benefits compared to advanced wet quenching are not so clear: 
- A plant in Germany added air to the CDQ cooling gas to reduce the hydrogen build-up for safety reasons. This resulted in a burn-off of about $2 \%$ of the coke produced.

- Advanced wet quenching is a process that cools the coke from top and bottom, which results in more rapid cooling. This does not result in energy recovery, but it does result in a highquality coke that can result in energy savings in the blast furnace.

The application of CDQ varies widely among countries (Figure 6). In Japan, high industrial electricity prices make CDQ economically attractive and the technology is installed at $95 \%$ of plants. In the Republic of Korea, $90 \%$ of all plants are equipped with CDQ. In other industrialised countries, the uptake of $C D Q$ is much lower. India has a very low share of $C D Q$, at about $10 \%$.

Figure 6: Use of coke dry quenching technology by country, 2004

Source: IEA, 2007

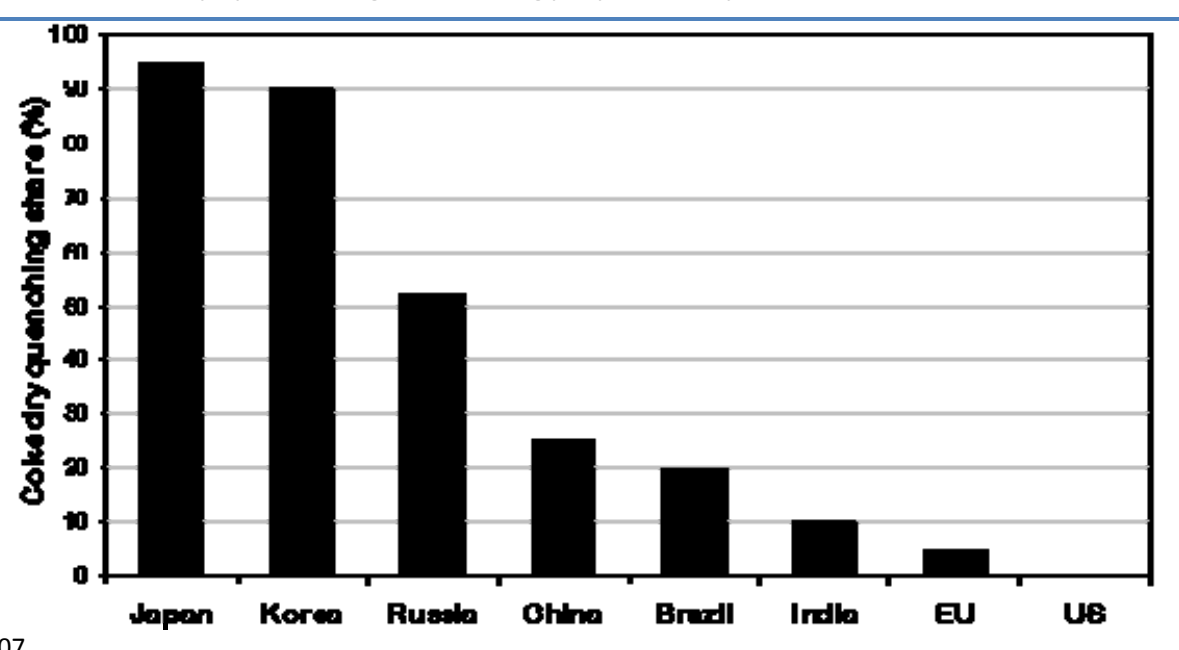

The blast furnace is the most energy-consuming step in the steel making, accounting for more than half of the total energy use in blast furnace steel making. Reducing agents such as coal and coke (among others) are used in blast furnaces and show a measure of efficiency (VDEh, 2009) (Figure 7).

Figure 7: Reducing agents consumption in Blast Furnaces in the world 2007/2008*/2009**

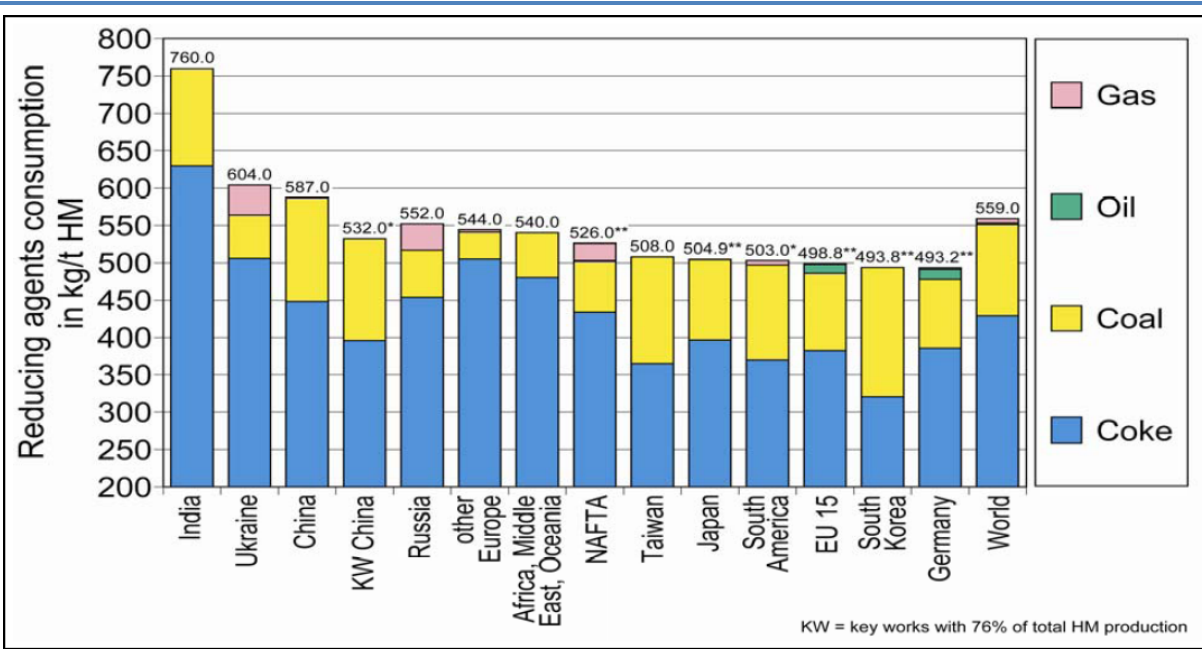

Note: EU15 includes Austria, Belgium, Denmark, Finland, France, Germany, Greece, Ireland, Italy, Luxembourg, the Netherlands, Portugal, Spain, Sweden and the United Kingdom.

Source: VDEh, 2009. 
The best-performing region - South America - uses 475 kilogram per tonne of hot metal ( $\mathrm{kg} / \mathrm{thm})$. On average, India uses $760 \mathrm{~kg} / \mathrm{thm}$, which is high compared with other countries. This corresponds with Indian sources (SAIL, 2005) that indicate total energy use for steel making is $60 \%$ to $75 \%$ above comparable plants in OECD countries. It should be stressed that the energy use for blast furnace steel making has been declining in India. However, the lack of suitable coking coal and the subsequent introduction of DRI processes has counteracted this positive development. Also, many options for waste heat and residual gas recovery are not yet fully used (SAIL, 2005).

\section{Best available technology and technical savings potential}

While disaggregated-level energy data are not currently available to construct detailed indicators, bottom-up estimates can be made of the energy and $\mathrm{CO}_{2}$ emissions reduction that could be achieved by applying BAT. It is possible to provide a breakdown of the estimated potential of technological efficiency based on current production volumes and current technologies (Figure 8). ${ }^{9}$

In the case of India, the potential energy savings that could be achieved by applying BATs amount to $7.7 \mathrm{Mtoe}$, about $20 \%$ of the energy use in Indian iron and steel sector. The estimated technical potential in India is slightly lower than that of most industrialised countries. The peculiarities of indigenous resources and industry, such as the high silica and alumina content in iron ore, lowquality coal and the existence of numerous small-scale plants, means that these technical savings might be harder to achieve and may be overstated.

Globally, the total potential energy saving is around 133 Mtoe (Figure 8). If achieved, this would result in $421 \mathrm{Mt} \mathrm{CO}_{2}$ avoided, about $19 \%$ of total direct $\mathrm{CO}_{2}$ emissions from the iron and steel industry.

Figure 8: Energy savings potential in 2007 for iron and steel, based on BAT

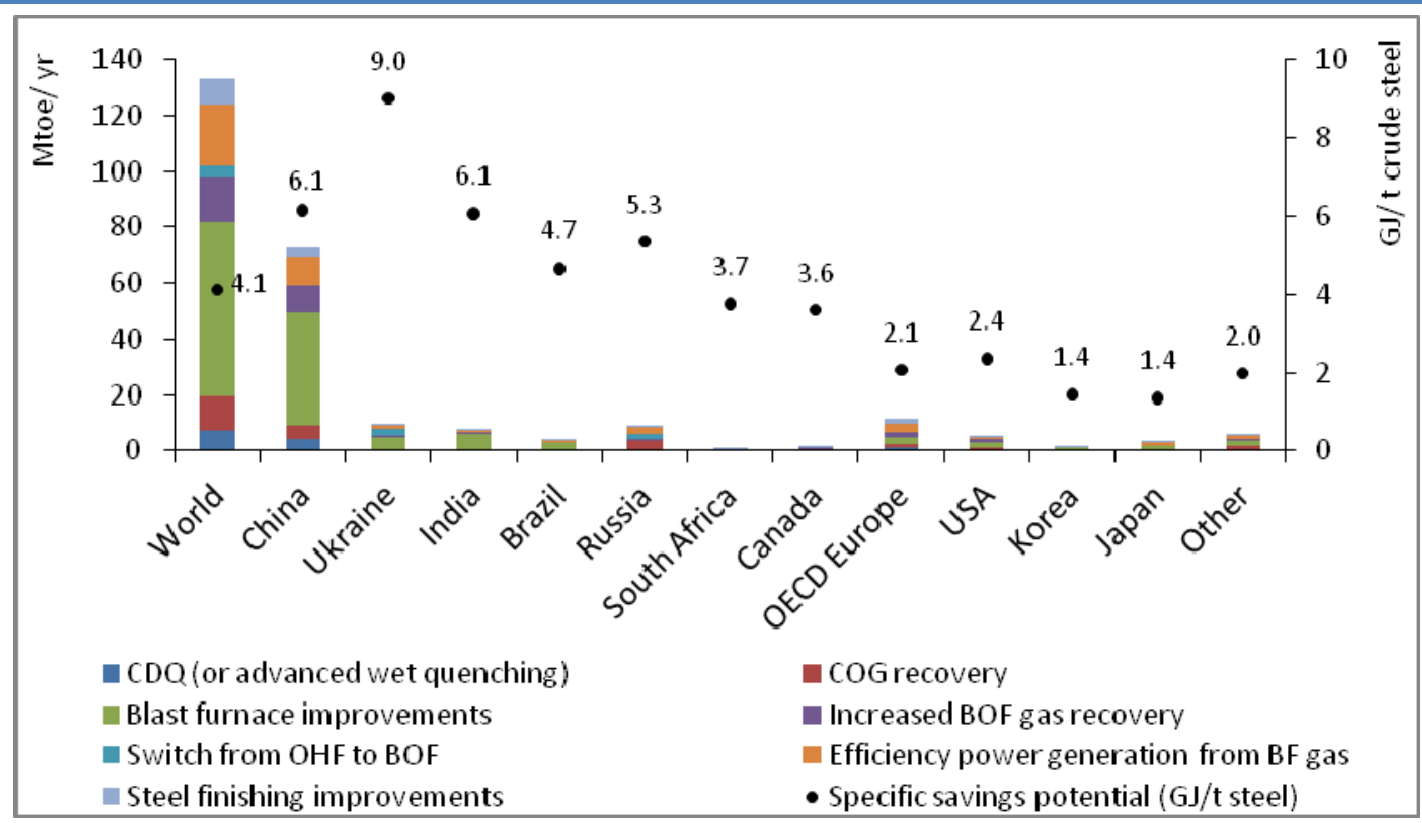

Note: $\mathrm{BF}=$ blast furnace; $\mathrm{OHF}=$ open-hearth furnace; $\mathrm{BOF}=$ basic oxygen furnace; $\mathrm{COG}=$ coke oven gas; and $\mathrm{CDQ}=\mathrm{coke}$ dry quenching

\footnotetext{
${ }^{9}$ The IEA strives to improve the quality of the underlying data and to refine the methodologies used in calculating the savings potential in the industrial sector.
} 
Although using BATs globally could result in significant energy and $\mathrm{CO}_{2}$ emissions reduction, their potential in the iron and steel sector is limited to around $22 \%$ of the global energy. This is considerably less than the energy demand growth that will result from production doubling between 2007 and 2050.

A global net reduction in energy consumption and $\mathrm{CO}_{2}$ emissions will therefore depend on significant innovation strategies to bring new technological solutions on stream well before 2050 . Smelting reduction, molten oxide electrolysis (MOE), and the use of waste plastic and hydrogen are among the technologies that should be further developed (IEA, 2009a).

The technical potential in iron and steel for reducing energy consumption is high. However, the economic potential for achieving these savings is significantly lower as it will require re-building or major refurbishment of plants. In some regions, such as India, with small-scale production and low-quality indigenous coal and iron ore, the potential to reduce energy consumption will be particularly difficult to achieve.

\section{Scenario results}

In India, energy consumption amounted to 49 kilograms per capita ( $\mathrm{kg} / \mathrm{cap}$ ) in 2007, one of the lowest rates in the world as compared to the average global of about $200 \mathrm{~kg} / \mathrm{cap}$. The current low per-capita consumption rate strengthens the argument that the domestic steel industry has enormous growth potential (Gol, 2010). Driven by strong economic development, increased income per capita and population growth, the energy consumption rate is expected to increase to between $200 \mathrm{~kg} / \mathrm{cap}$ and $250 \mathrm{~kg} / \mathrm{cap}$ by 2050 . To meet this strong domestic demand, crude steel production is estimated to increase from $53 \mathrm{Mt}$ in 2007 to between $266 \mathrm{Mt}$ and $355 \mathrm{Mt}$ in 2050.

Table 6: India's iron and steel production by scenarios, Mt

\begin{tabular}{|c|c|c|c|c|c|c|c|c|c|c|c|c|c|}
\hline & \multirow[t]{2}{*}{2007} & \multicolumn{3}{|c|}{$\begin{array}{l}\text { Baseline } \\
\text { low-demand }\end{array}$} & \multicolumn{3}{|c|}{$\begin{array}{c}\text { Baseline } \\
\text { high-demand }\end{array}$} & \multicolumn{3}{|c|}{$\begin{array}{c}\text { BLUE } \\
\text { low-demand }\end{array}$} & \multicolumn{3}{|c|}{$\begin{array}{c}\text { BLUE } \\
\text { high-demand }\end{array}$} \\
\hline & & 2015 & 2030 & 2050 & 2015 & 2030 & 2050 & 2015 & 2030 & 2050 & 2015 & 2030 & 2050 \\
\hline Crude Steel & 53 & 131 & 200 & 266 & 169 & 242 & 355 & 131 & 200 & 266 & 169 & 242 & 355 \\
\hline EF steel & 31 & 35 & 72 & 138 & 40 & 84 & 168 & 32 & 43 & 51 & 35 & 43 & 63 \\
\hline BOF/BF & 22 & 96 & 128 & 128 & 129 & 158 & 187 & 99 & 157 & 215 & 134 & 199 & 292 \\
\hline BF pig iron & 29 & 96 & 128 & 128 & 129 & 158 & 187 & 99 & 150 & 190 & 134 & 184 & 242 \\
\hline $\begin{array}{l}\text { Smelting } \\
\text { reduction } \\
\text { metal }\end{array}$ & 0 & 0 & 0 & 0 & 0 & 0 & 0 & 0 & 7 & 25 & 0 & 15 & 50 \\
\hline $\begin{array}{l}\text { Gas-based } \\
\text { DRI }\end{array}$ & 5 & 7 & 10 & 11 & 8 & 11 & 12 & 8 & 12 & 13 & 9 & 14 & 15 \\
\hline $\begin{array}{l}\text { Coal-based } \\
\text { DRI }\end{array}$ & 13 & 33 & 69 & 120 & 38 & 79 & 143 & 11 & 7 & 2 & 8 & 0 & 0 \\
\hline Scrap & 10 & 24 & 38 & 51 & 31 & 46 & 70 & 25 & 40 & 57 & 32 & 48 & 76 \\
\hline
\end{tabular}

India will become the second-largest producer of steel by 2015 and will remain so throughout the projection period. India's share of global crude steel production will increase from the current rate of $4 \%$ to reach more than $10 \%$ in 2050 . About $18 \%$ of India's steel production in 2007 was 
from recycled steel; this share is estimated to increase to $19 \%$ in 2050 in the Baseline Scenario and to $22 \%$ in the BLUE Scenario. Under the Baseline Scenario, coal-based DRI represents a growing share of iron production (Table 6).

The picture that emerges from the BLUE Scenario for India is totally different than that of the Baseline Scenario. The production of coal-based DRI will be phased out and replaced by production Page | 32 from BF/BOF equipped with carbon capture and storage (CCS). As a result, the production of crude steel from electric furnaces will decrease from $58 \%$ in 2007 to less than $20 \%$ in 2050.

The large differences in production and process routes used in the two scenarios will have a strong impact on the energy efficiency and $\mathrm{CO}_{2}$ intensity of the iron and steel sector. Under the BLUE Scenario, energy intensity in 2050 will be about $28 \%$ lower and $\mathrm{CO}_{2}$ intensity between $53 \%$ and $58 \%$ lower than under the Baseline Scenario (Figure 9). Applying CCS in blast furnaces explains the greater improvement in $\mathrm{CO}_{2}$ intensity. Despite these important improvements, the intensities in India are expected to remain higher than the world average partly due to the limited recycled steel available and the poor quality of coking coal and iron ore.

Figure 9: Iron and steel energy and direct $\mathrm{CO}_{2}$ intensity for low-demand scenarios, India and world average

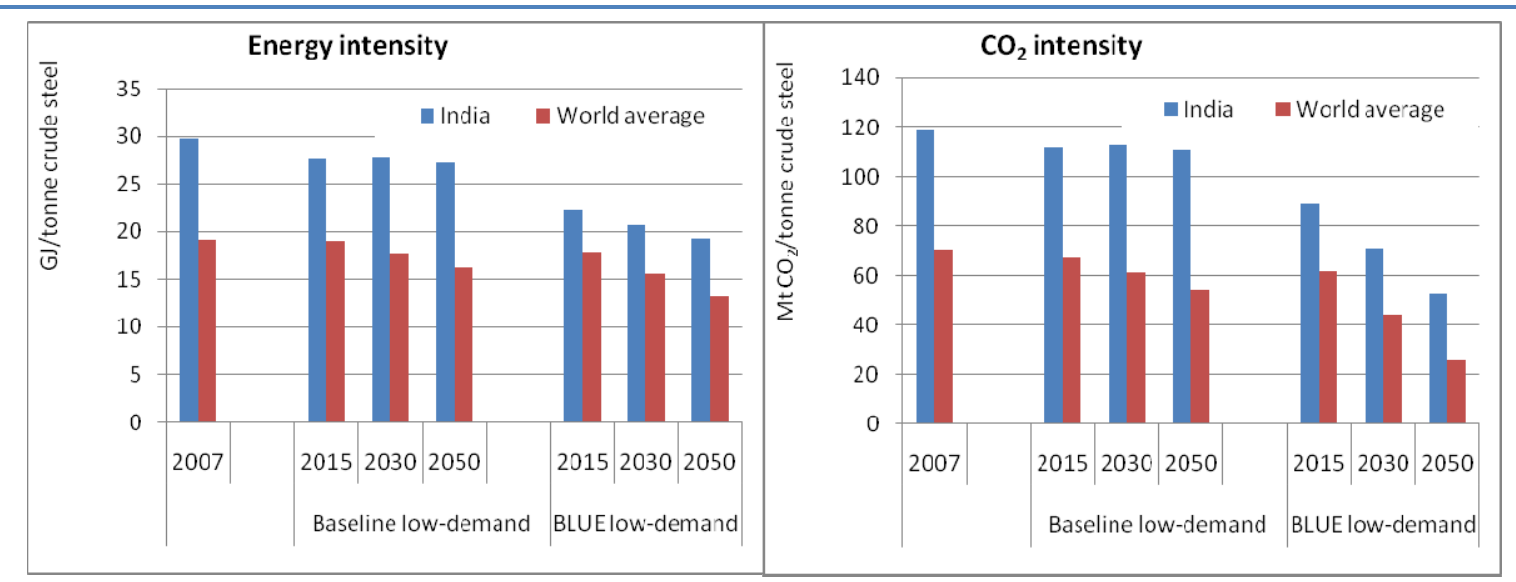

In the Baseline Scenario, iron and steel energy use in India increases from 38 Mtoe in 2007 to 173 Mtoe and 211 Mtoe in the low- and high-demand cases in 2050. Total direct emissions rise 4.7 and 5.7 times, reaching $703 \mathrm{Mt} \mathrm{CO}_{2}$ and $858 \mathrm{Mt} \mathrm{CO}_{2}$.

In the BLUE Scenario, changes in production process and further improvements in energy efficiency significantly reduce energy intensity. But given the expected growth in steel production, energy use will still rise and reach 98 Mtoe and 153 Mtoe in the low- and highdemand cases in 2050. Furthermore, the use of CCS in the BLUE Scenario to reduce $\mathrm{CO}_{2}$ emissions increases energy consumption, offsetting some of the savings from higher energy efficiency that would otherwise be achieved.

$\mathrm{CO}_{2}$ emissions for iron and steel in the BLUE Scenario for India would still be higher than the 2007 level. But compared to the Baseline Scenario, $\mathrm{CO}_{2}$ emissions in 2050 would be $53 \%$ lower in the low-demand case and $58 \%$ lower in the high-demand case (Figure 10). The reduction in $\mathrm{CO}_{2}$ emissions in the BLUE Scenario largely results from technological innovation and efficiency gains, and the introduction of CCS. Total direct emissions reduction amount to $370 \mathrm{Mt} \mathrm{CO}_{2}$ in the lowdemand case and to $496 \mathrm{Mt} \mathrm{CO}_{2}$ in the high-demand case in 2050 . CCS contributes $39 \%$ and $47 \%$ of the total reduction in 2050 (Figure 10). 
Figure 10: India's direct $\mathrm{CO}_{2}$ emissions reduction by technology option for iron and steel

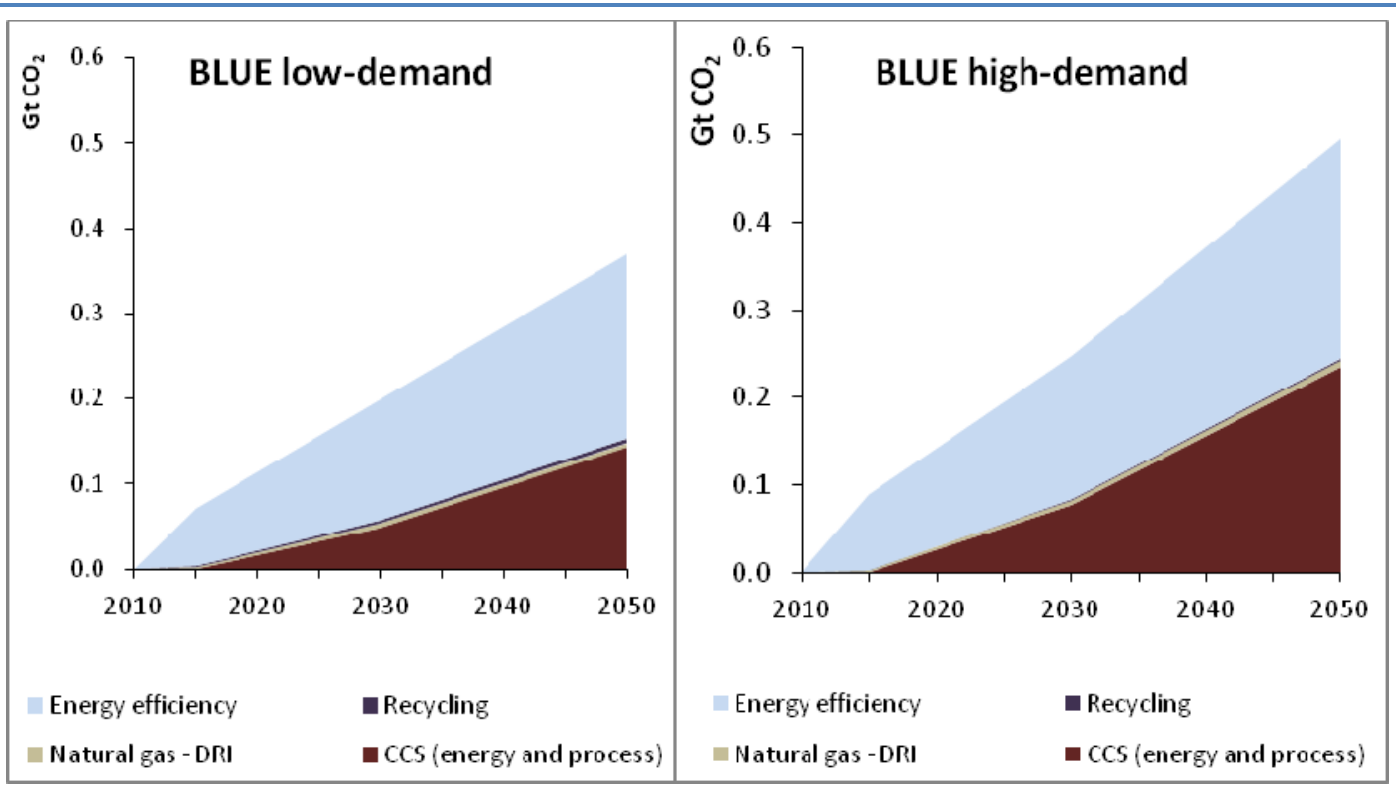

Globally, crude steel production is estimated to increase from $1351 \mathrm{Mt}$ in 2007 to $2408 \mathrm{Mt}$ in the low-demand case and $2857 \mathrm{Mt}$ in the high-demand case in 2050. In both cases, China remains the main crude steel producer, accounting for about $30 \%$ of world production in 2050 . India, other developing Asia, Africa and the Middle East will have the strongest growth rates; in 2050 between $32 \%$ and $35 \%$ of all production will be from these countries/regions.

In the BLUE Scenario, total direct $\mathrm{CO}_{2}$ emissions from steel production reach about 1.5 gigatonnes of $\mathrm{CO}_{2}\left(\mathrm{Gt} \mathrm{CO}_{2}\right)$ in 2050. This represents a decrease of about $35 \%$ to $37 \%$ in direct $\mathrm{CO}_{2}$ emissions compared to 2007. Initially, reduction from recycling dominates (Figure 11). From 2020 onwards, fuel switching and CCS start to play a more important role. Total direct emissions

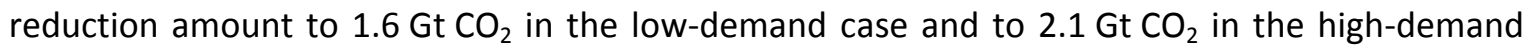
case in 2050. Production from recycled steel in the BLUE Scenario is expected to rise from $444 \mathrm{Mt}$ in 2007 to $1207 \mathrm{Mt}$ and $1470 \mathrm{Mt}$ in 2050.

Figure 11: Global direct $\mathrm{CO}_{2}$ emissions reduction by technology option for iron and steel
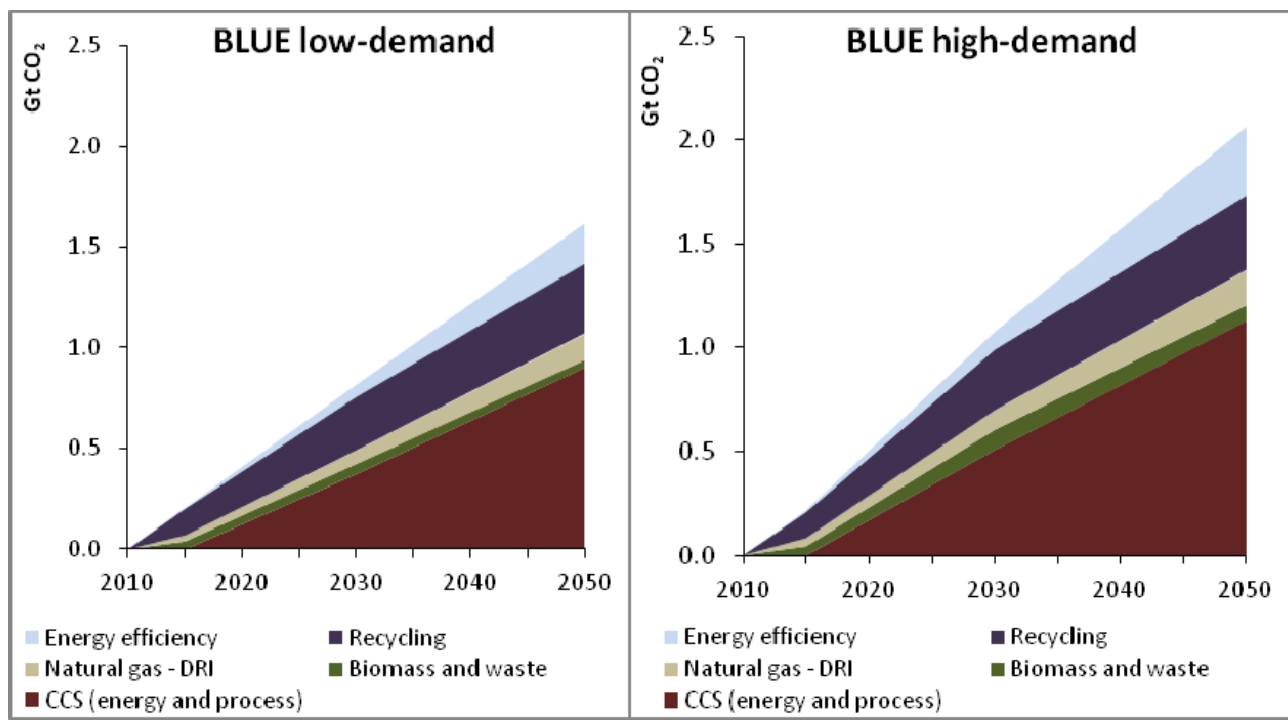
In the Baseline Scenario, total emissions are expected to continue to rise year on year from $2.3 \mathrm{Gt} \mathrm{CO}_{2}$ in 2007 to $3.1 \mathrm{Gt} \mathrm{CO}_{2}$ (low-demand) and $3.5 \mathrm{Gt} \mathrm{CO}_{2}$ (high-demand) in 2050 . As crude steel production will increase marginally in OECD countries between 2007 and 2050 , by $2 \%$ and $5 \%$ in the low- and high-demand cases, their emissions under the Baseline Scenario will decrease by about $30 \%$ over the same period. By contrast, production in non-OECD countries will increase by $129 \%$ and $182 \%$ between 2007 and 2050 , with emissions increasing by $62 \%$ and $86 \%$.

In the BLUE Scenario, global emissions peak between 2015 and 2020, and then begin to decline as more efficient and cleaner technologies are introduced. Emissions from OECD countries are 65\% and 68\% lower than in the Baseline Scenario in 2050; about 75\% lower than 2007 levels. For non-OECD countries, emissions would be $50 \%$ and $58 \%$ lower than in the Baseline Scenario; representing a $19 \%$ to $22 \%$ decrease from 2007.

With lower rates of production growth than developing countries, the contribution to reducing emissions from OECD countries in 2050 will be much smaller (Figure 12). Although it is important that OECD countries take the lead in terms of technology deployment and diffusion, the implementation of policy and measures to achieve reductions in $\mathrm{CO}_{2}$ emissions in $\mathrm{OECD}$ countries alone will not be sufficient to reduce global emissions from industry. Non-OECD countries will also need to contribute.

Figure 12: Regional contribution to reducing global direct $\mathrm{CO}_{2}$ emissions in iron and steel, lowdemand case

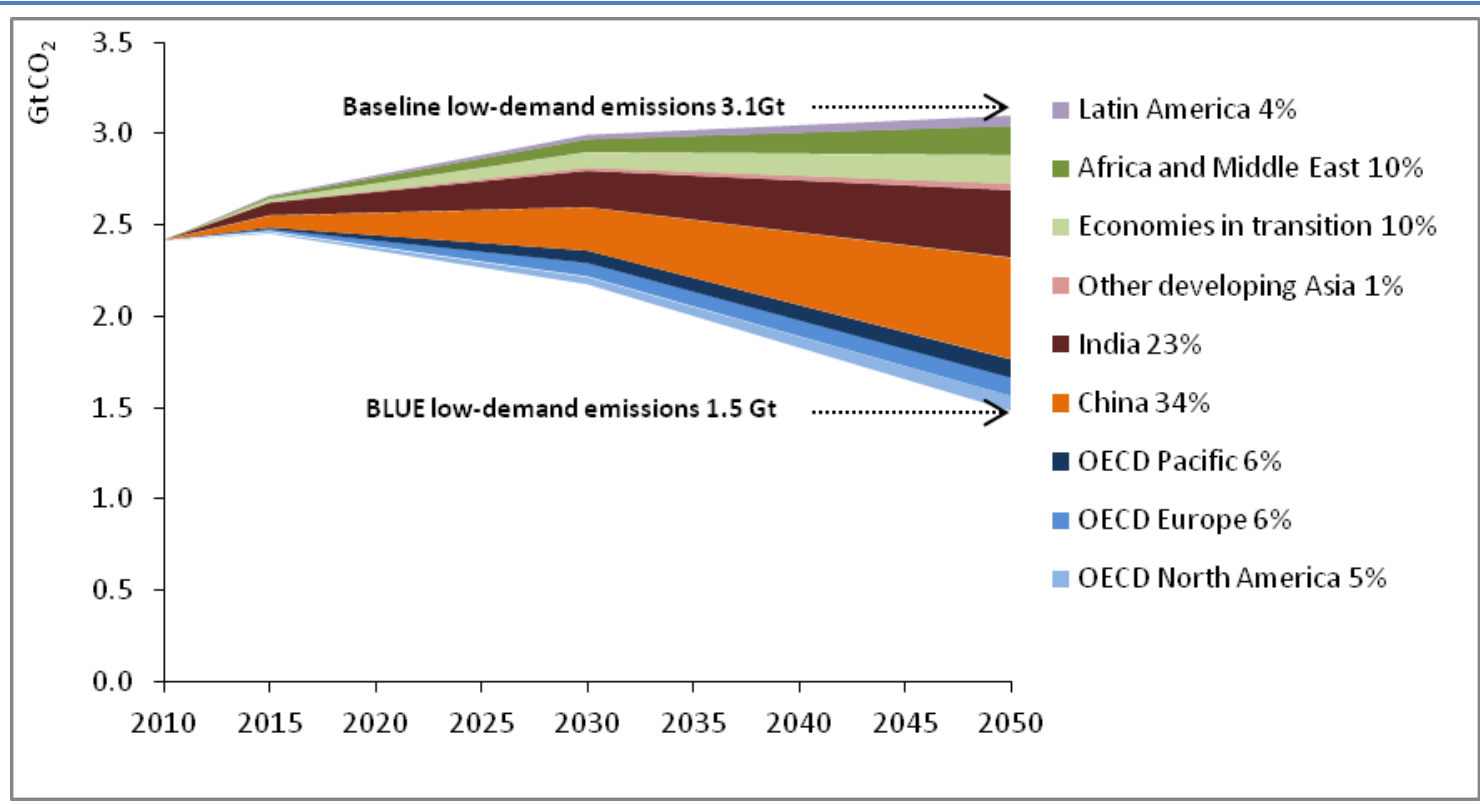

\section{Technology options in the iron and steel sector}

In order to reach the targets set out in the BLUE Scenario, a number of technology options need to be developed and deployed in the iron and steel sector both in India and globally.

Natural gas-based DRI production, which is a well-established technology, means that coal could be completely replaced. Such plants use relatively small gas reserves. Gas can also be injected into blast furnaces, but volumes are limited by process conditions. In the case of India, there is limited opportunity for this option given the limited resources of natural gas and its growing use in the chemical and petrochemical sector. Biomass, plastic waste, $\mathrm{CO}_{2}$-free electricity and 
hydrogen are other future options. The deployment milestones indicate some of the main technology assumptions in the BLUE Scenario (Table 7).

Table 7: Technology options for the iron and steel industry

\begin{tabular}{|c|c|c|c|}
\hline Technology & R\&D needs & Demonstration needs & Deployment milestones \\
\hline \multirow[t]{6}{*}{ Smelting reduction } & $\begin{array}{l}\text { Improve heat exchange in } \\
\text { FINEX* }\end{array}$ & \multirow[t]{2}{*}{$\begin{array}{l}\text { Demonstration plants } \\
\text { already operational for } \\
\text { FINEX and HIsmelt }\end{array}$} & \multirow{2}{*}{$\begin{array}{l}\text { In India, share rise to } \\
\text { between } 9 \% \text { and } 14 \% \text { in } \\
2050\end{array}$} \\
\hline & \multirow{2}{*}{$\begin{array}{l}\text { New configuration of } \\
\text { HIsmelt*^ to lower coal } \\
\text { consumption }\end{array}$} & & \\
\hline & & \multirow{2}{*}{$\begin{array}{l}\text { Demonstration plant for } \\
\text { producing reduced pellets } \\
\text { operational by } 2015\end{array}$} & \multirow{4}{*}{$\begin{array}{l}\text { Globally, share rise to } \\
\text { between } 5 \% \text { and } 8 \% \text { in } \\
2050\end{array}$} \\
\hline & \multirow{2}{*}{$\begin{array}{l}\text { Integration of HIsmelt and } \\
\text { Isarna }{ }^{\star * \star} \text { processes } \\
\text { (Hisarna). Pilot plantis under } \\
\text { construction }\end{array}$} & & \\
\hline & & \multirow[t]{2}{*}{$\begin{array}{l}\text { Demonstration plant with } \\
\text { smelter by } 2020\end{array}$} & \\
\hline & Paired straight hearth furnace & & \\
\hline \multirow{3}{*}{$\begin{array}{l}\text { Top-gas recycling } \\
\text { blast furnace }\end{array}$} & \multirow{3}{*}{$\begin{array}{l}\text { Trial on existing experimental } \\
\text { furnace successful }\end{array}$} & \multirow{2}{*}{$\begin{array}{l}\text { Commercial scale } \\
\text { demonstration - small blast } \\
\text { furnace - by } 2014\end{array}$} & Deployment in 2020 \\
\hline & & & \multirow{2}{*}{$\begin{array}{l}\text { Contribute to a } 40 \% \\
\text { decrease between } 2007 \\
\text { and } 2050 \text { in coke needs in } \\
\text { India }\end{array}$} \\
\hline & & $\begin{array}{l}\text { Full scale demonstration } \\
\text { plant by } 2016\end{array}$ & \\
\hline \multirow{3}{*}{$\begin{array}{l}\text { Use of charcoal and } \\
\text { waste plastic }\end{array}$} & Proven technologies & & \multirow{2}{*}{$\begin{array}{l}\text { No use of biomass and } \\
\text { waste in India }\end{array}$} \\
\hline & \multirow{2}{*}{$\begin{array}{l}\text { Research needs to focus on } \\
\text { improving the mechanical } \\
\text { stability of charcoal }\end{array}$} & & \\
\hline & & & $\begin{array}{l}\text { Between } 36 \text { Mtoe and } \\
66 \text { Mtoe of charcoal and } \\
\text { waste plastic used globally } \\
\text { in } 2050\end{array}$ \\
\hline \multirow{2}{*}{$\begin{array}{l}\text { Production of iron } \\
\text { by molten oxide } \\
\text { electrolysis }\end{array}$} & \multirow{2}{*}{$\begin{array}{l}\text { Assessment of technical } \\
\text { feasibility and optimum } \\
\text { operating parameters }\end{array}$} & \multirow{2}{*}{$\begin{array}{l}\text { If the laboratory-scale } \\
\text { project is successful, } \\
\text { demonstration may start in } \\
\text { the next } 15 \text { to } 20 \text { years }\end{array}$} & Deployment after 2035 \\
\hline & & & $\begin{array}{l}\text { Marginal market share in } \\
\text { India by } 2050\end{array}$ \\
\hline \multirow[t]{2}{*}{ Hydrogen smelting } & \multirow{2}{*}{$\begin{array}{l}\text { Assessment of technical } \\
\text { feasibility and optimum } \\
\text { operating parameters }\end{array}$} & \multirow{2}{*}{$\begin{array}{l}\text { If the laboratory-scale } \\
\text { project is successful, } \\
\text { demonstration may start in } \\
\text { the next } 15 \text { to } 20 \text { years }\end{array}$} & Deployment after 2035 \\
\hline & & & $\begin{array}{l}\text { Marginal market share in } \\
\text { India by } 2050\end{array}$ \\
\hline CCS for blast furnaces & $\begin{array}{l}\text { Research focusing on } \\
\text { reducing the energy used in } \\
\text { capture }\end{array}$ & 2015-20 & $\begin{array}{l}75 \% \text { to } 90 \% \text { of all new } \\
\text { plants built between } 2030 \\
\text { and } 2050 \text { equipped with } \\
\text { CCS }\end{array}$ \\
\hline CCS for DRI & & $2015-20$ & $\begin{array}{l}75 \% \text { to } 90 \% \text { of all new } \\
\text { plants built between } 2030 \\
\text { and } 2050 \text { equipped with } \\
\text { CCS }\end{array}$ \\
\hline $\begin{array}{l}\text { CCS for smelting } \\
\text { reduction }\end{array}$ & & $2020-30$ & $\begin{array}{l}75 \% \text { to } 90 \% \text { of all new } \\
\text { plants built between } 2030 \\
\text { and } 2050 \text { equipped with } \\
\text { CCS }\end{array}$ \\
\hline
\end{tabular}

Notes: *FINEX is a smelting reduction process developed by Pohang Iron and Steel Company (POSCO), which consists of a melting furnace with a liquid iron bath in which coal is injected and a cascade of fluidised bed reactors for the pre-reduction of iron fines.

**Hlsmelt (high-intensity smelting) is an iron bath reactor process.

***Isarna is a smelting reduction technology under development by the consortium ULCOS. It is a highly energy-efficient iron-making process based on direct smelting of iron-ore fines using a smelting cyclone in combination with a coal-based smelter. All process steps are directly hot-coupled, avoiding energy losses from intermediate treatment of materials and process gases. 


\section{Cement}

\section{Overview and context}

India's cement industry is the third-largest industrial energy consumer and second-largest $\mathrm{CO}_{2}$ emitter in the country's industrial sector. India, which is the second-largest cement producer in the world, has seen its annual production rise from $95 \mathrm{Mt}$ in 2000 to $170 \mathrm{Mt}$ in 2007. The main factors prompting this growth include: the real estate boom during 2004-08; increased investments in infrastructure by both the private sector and government; and higher governmental spending under various social programmes (Gol, 2010b).

The Indian cement industry comprises 148 large and 365 mini cement plants, with average installed capacities of $219 \mathrm{Mt}$ and $11 \mathrm{Mt}$ respectively as of March 2009 (CMA, 2010). The majority of large kilns are among the most energy efficient in the world. The total installed capacity of large kilns has increased by $42 \%$ since 2005 (IBEF, 2009).

India has a clinker-to-cement ratio of 0.84 i.e. 0.84 tonnes of clinker are used per tonne of cement produced. In comparison, China has a clinker-to-cement ratio of about 0.74 and the world average is 0.79. A low clinker-cement ratio contributes significantly to lower energy use per tonne of cement.

In 2007, India used about 3.2 gigajoules of energy per tonne (GJ/t) of cement, compared with $3.0 \mathrm{GJ} / \mathrm{t}$ cement for the most energy efficient country (Japan) and a world average of $3.6 \mathrm{GJ} / \mathrm{t}$ cement. The energy intensity of India's cement industry has improved by $1.5 \%$ per year in the last 15 years. India uses about 78 kilowatt-hours $(\mathrm{kWh})$ of electricity per tonne of cement. This value is the lowest in the world and even lower than the estimated BAT value of $95 \mathrm{kWh} / \mathrm{t}$ to $100 \mathrm{kWh} / \mathrm{t}$ cement. It is not verifiable if stand-alone grinding stations and small kilns are included in the data. Nevertheless, based on the technology characteristics and data available from large cement producers, the energy efficiency of India's cement production and the electricity intensity are clearly better than the world average.

Table 8: Global cement production, 2007

\begin{tabular}{|c|c|c|c|}
\hline & Production (Mt/yr) & $\begin{array}{l}\text { Production } \\
\text { share (\%) }\end{array}$ & $\begin{array}{c}\text { Cumulative production } \\
\text { share }(\%)\end{array}$ \\
\hline China & 1354 & 48.8 & 48.8 \\
\hline United States & 97 & 3.5 & 58.4 \\
\hline Korea & 57 & 2.1 & 65.1 \\
\hline Spain & 55 & 2.0 & 67.1 \\
\hline Turkey & 50 & 1.8 & 68.8 \\
\hline World & 2774 & 100 & \\
\hline
\end{tabular}

Source: USGS, 2009a.

Globally, the cement sector is the third-largest energy consumer in industry and the secondlargest $\mathrm{CO}_{2}$ emitter. Although energy intensity per tonne of product is less than that of other energy-intensive materials such as aluminium and steel, the volume of production is much 
higher. The energy consumption, $\mathrm{CO}_{2}$ intensity and volume of cement produced means that the sector accounts for more than one-quarter of the direct $\mathrm{CO}_{2}$ emissions from industry.

World cement production was 2774 Mt in 2007 (USGS, 2009a). The top four producing countries, China, India, the United States and Japan, account for more than $60 \%$ of the global production (Table 8).

Global cement production grew from $594 \mathrm{Mt}$ in 1970 to $2774 \mathrm{Mt}$ in 2007, an increase of about $4.3 \%$ per year. Driven by the rapid economic growth in developing countries in recent years, cement production accelerated to $7.7 \%$ per year between 2000 and 2007.

\section{Technology and energy consumption in cement production}

The thermal energy consumption of the cement industry is strongly linked to the type of kiln used. Vertical shaft kilns, of which there are three main types, consume between $4.8 \mathrm{GJ} / \mathrm{t}$ and $6.7 \mathrm{GJ} / \mathrm{t}$ clinker. The intensity of wet kilns varies between $5.9 \mathrm{GJ} / \mathrm{t}$ and $6.7 \mathrm{GJ} / \mathrm{t}$ clinker. The long dry process requires around $4.6 \mathrm{GJ} / \mathrm{t}$ clinker, whereas adding pre-heaters and pre-calciners further reduces the energy requirement to between $2.9 \mathrm{GJ} / \mathrm{t}$ and $3.5 \mathrm{GJ} / \mathrm{t}$ clinker. The more efficient dry-process kiln (with pre-heaters and pre-calciners) is the technology of choice for new plants as shown by trends in the stock of plants in operation (Figure 13). Since 1990, dry technologies have exhibited a marked increase in all the regions for which data are available. At a country level, however, the share of the more energy-efficient dry process varies significantly, by between $12 \%$ and $100 \%$ (IEA, 2007).

Figure 13: Share of cement-kiln technology

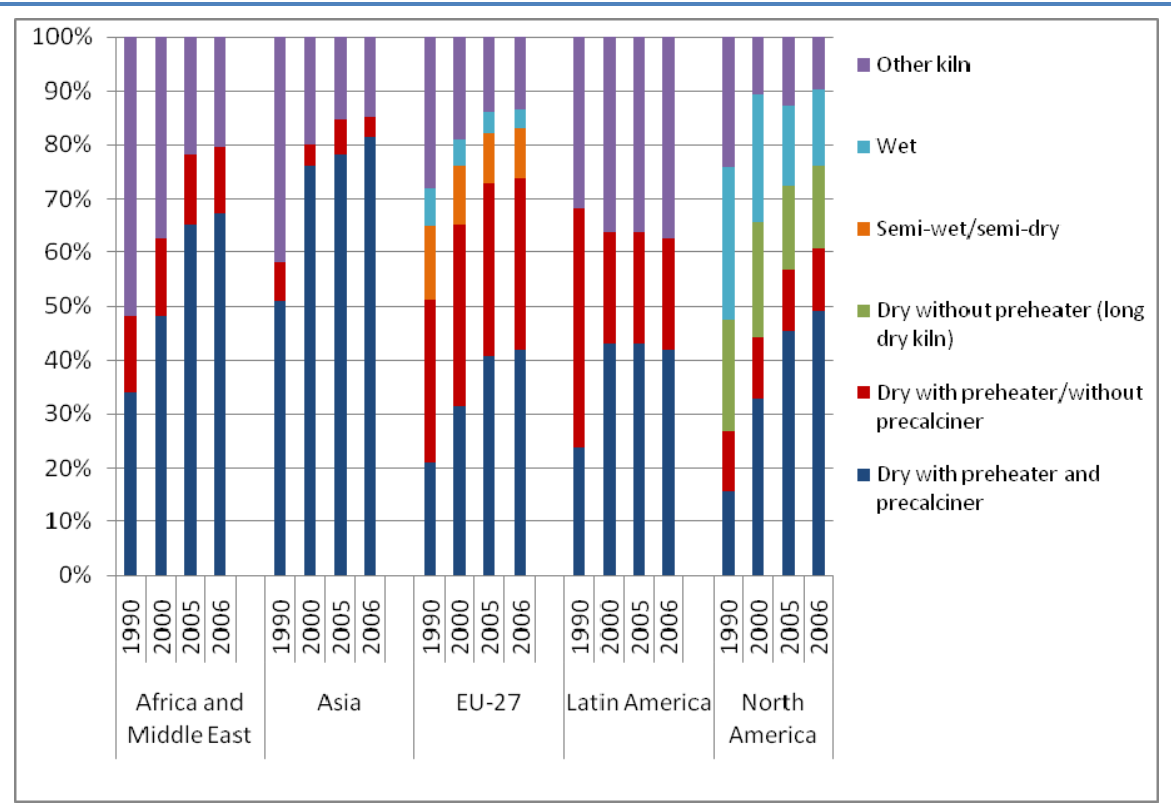

Source: CSI, 2008.

The increasing share of dry-process kilns with pre-heaters and pre-calciners has had a positive impact on energy consumption in clinker production. Higher energy prices in recent years, coupled with buoyant global economic growth and increased demand for cement, has resulted in lower energy intensities. Developing countries have added new large-scale, dry-process capacity to meet demand, thereby reducing the share of smaller, less efficient kilns. Higher energy prices have also encouraged cement producers in developed countries to invest in new more efficient plants or retrofits to improve energy efficiency. In 2006, Japan and India were the most efficient clinker producers (Figure 14). 
Figure 14: Thermal energy consumption per tonne of clinker

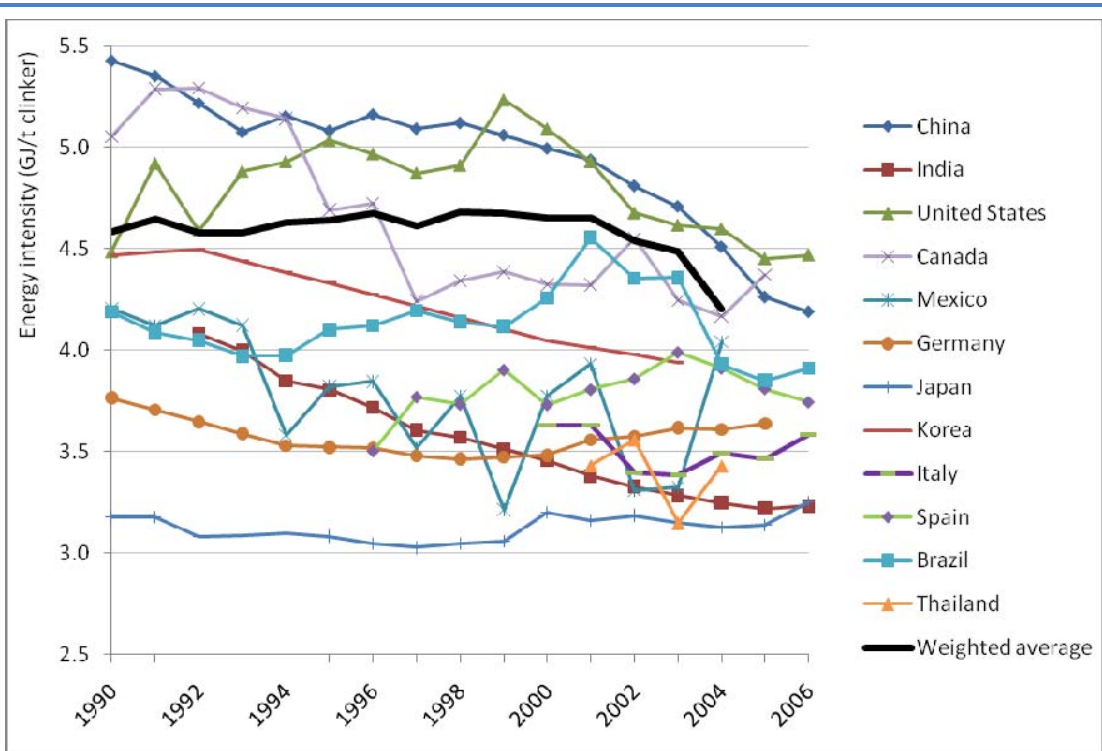

Note: Care must be taken in interpreting the absolute values of data in this figure, given the possibility that different system boundaries and measurement methods (low- or high-heating value) may have been used. The Japanese method of calculating net energy consumption per tonne of clinker yields a value $2.94 \mathrm{GJ} / \mathrm{t}$ clinker for 2006. The data for Japan have a break in the time series for clinker production in 2000 when a different definition of clinker was adopted.

Sources: CSI, 2008; Soares and Tolmasquim, 2000; Worrell et al., 2001; IBGE, 2008; EEA, 2006; AITEC, 2008; USGS, 2008c; PCA, 2008; NRCan, 2008; JCA, 2006 and METI, 2008; OFICEMEN, 2007; Siam Cement Company Ltd., 2005; INEGI, 2008; VDZ, 2008; Battelle, 2002; LBNL, IEA and Tshinghua University estimates.

\section{Best available technology and technical savings potential}

Current BAT for the cement industry is a dry-process kiln with pre-heater and pre-calciner. Up to six stages of pre-heating can be used if the raw material feed has a low-moisture content $(<6 \%$; VDZ, 2008), although a five-stage pre-heater is the norm in Europe for new plants. BAT for sixstage pre-heater and pre-calciner kilns is in the range of $2.9 \mathrm{GJ} / \mathrm{t}$ and $3.3 \mathrm{GJ} / \mathrm{t}$ clinker. For fivestage pre-heater and pre-calciner kilns, this range is between $3.1 \mathrm{GJ} / \mathrm{t}$ and $3.5 \mathrm{GJ} / \mathrm{t}$ clinker. BAT for electricity consumption in the cement industry depends on the type of plant, but is assumed to be in the range of $95 \mathrm{kWh} / \mathrm{t}$ to $100 \mathrm{kWh} / \mathrm{t}$ cement. The increased use of alternative fuels, however, tends to increase electricity consumption for pre-treatment and handling.

India has one of the lowest potential for reducing its energy efficiency by applying BAT in cement. Over two-thirds of this potential lies in the increased use of fly ash and other clinker substitutes as the current energy intensity for many plants are among the most efficient in the world. The potential for saving energy in India's cement sector by applying current BAT and increasing the clinker substitutes is an estimated $18 \%$ from current levels.

Globally, if all plants were BAT, assuming an average fuel need of $3.2 \mathrm{GJ} / \mathrm{t}$ clinker, 42 Mtoe of thermal fuel use could be saved. Shifting to BAT for electricity consumption would achieve savings of around 5.2 Mtoe or 61 terawatt-hours (TWh). Taking into account all the potentials, the global intensity of cement production could be reduced by $0.9 \mathrm{GJ} / \mathrm{t}$ cement produced, with significantly higher savings possible in many countries and regions (Figure 15). ${ }^{10}$

\footnotetext{
${ }^{10}$ The calculation of potential savings is based on the assumption that the energy efficiency of cement kilns is improved first, so that subsequent savings are evaluated relative to the BAT and energy savings from clinker substitutes are based on the BAT level of energy consumption. An alternative approach would have been to assess the savings from clinker substitutes at current energy efficiencies and then assess the BAT savings from the lower level of clinker demand. This approach would have yielded a slightly lower share of savings from energy efficiency and slightly more from clinker substitutes.
} 
Figure 15: Energy-savings potential in 2007 for cement, based on BAT

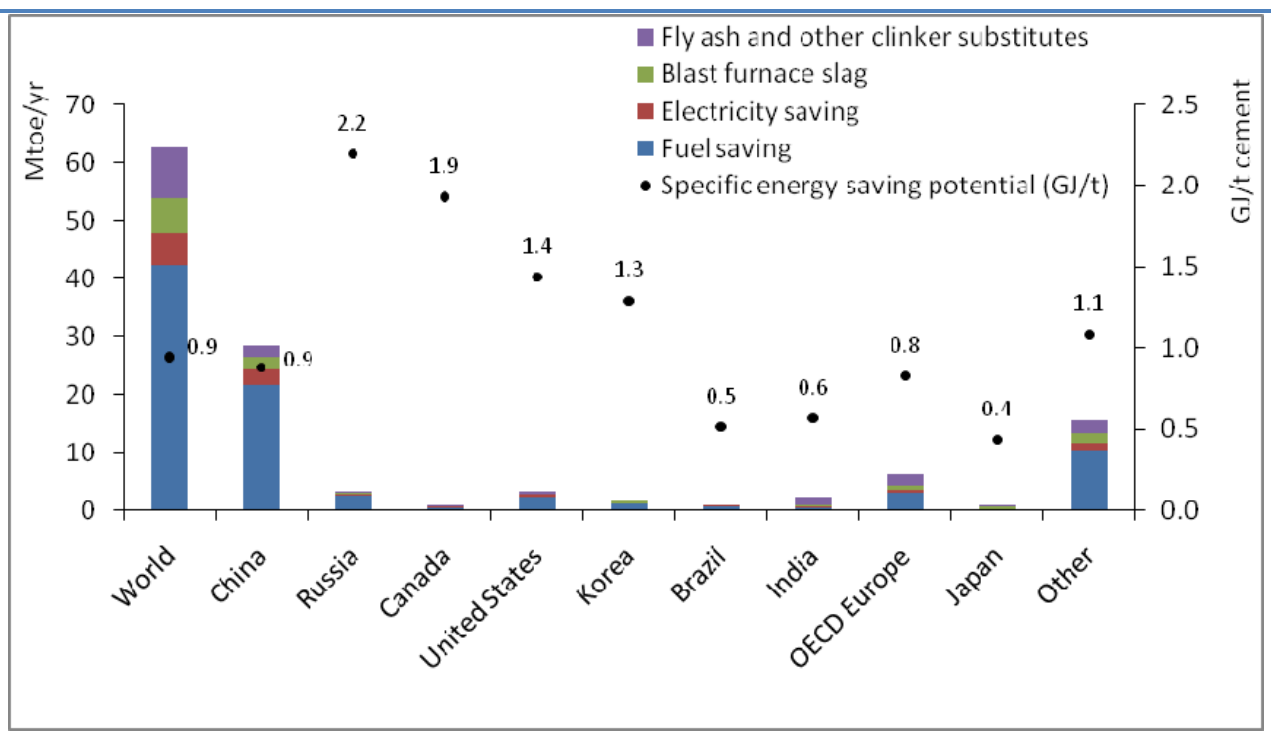

\section{Scenario results}

Despite India's strong growth in demand for cement in recent years, the 2007 consumption of $151 \mathrm{~kg} / \mathrm{cap}$ is one of the lowest in the world and well below the global average of $420 \mathrm{~kg} / \mathrm{cap}$. But as gross domestic product (GDP) rises, the growth in domestic cement demand is expected to remain strong and to rise to between $400 \mathrm{~kg} / \mathrm{cap}$ and $460 \mathrm{~kg} / \mathrm{cap}$ in 2050 . Annual production could reach $646 \mathrm{Mt}$ and $742 \mathrm{Mt}$ by 2050, increasing production by between 3.8 and 4.4 times in 2050 compared to current levels.

Table 9: India's cement industry main indicators by scenarios

\begin{tabular}{|c|c|c|c|c|c|c|c|c|c|c|c|c|c|}
\hline & & \multicolumn{3}{|c|}{$\begin{array}{l}\text { Baseline } \\
\text { low-demand }\end{array}$} & \multicolumn{3}{|c|}{$\begin{array}{c}\text { Baseline } \\
\text { high-demand }\end{array}$} & \multicolumn{3}{|c|}{$\begin{array}{c}\text { BLUE } \\
\text { low-demand }\end{array}$} & \multicolumn{3}{|c|}{$\begin{array}{c}\text { BLUE } \\
\text { high-demand }\end{array}$} \\
\hline & 2007 & 2015 & 2030 & 2050 & 2015 & 2030 & 2050 & 2015 & 2030 & 2050 & 2015 & 2030 & 2050 \\
\hline $\begin{array}{l}\text { Cement } \\
\text { consumption } \\
\text { (kg/cap) }\end{array}$ & 151 & 225 & 325 & 400 & 234 & 364 & 460 & 225 & 325 & 400 & 234 & 364 & 460 \\
\hline Production (Mt) & 170 & 291 & 482 & 646 & 303 & 540 & 742 & 291 & 482 & 646 & 303 & 540 & 742 \\
\hline $\begin{array}{l}\text { Clinker-to- } \\
\text { cement ratio }\end{array}$ & 0.84 & 0.80 & 0.76 & 0.75 & 0.80 & 0.76 & 0.75 & 0.77 & 0.72 & 0.71 & 0.76 & 0.72 & 0.69 \\
\hline $\begin{array}{l}\text { Energy use } \\
\text { (Mtoe) }\end{array}$ & 13.1 & 20.6 & 32.0 & 41.8 & 21.4 & 35.6 & 47.8 & 19.8 & 32.7 & 48.6 & 20.3 & 36.3 & 54.9 \\
\hline Coal & 11.4 & 17.7 & 27.3 & 35.6 & 18.4 & 30.4 & 40.7 & 14.5 & 20.2 & 26.4 & 14.1 & 19.7 & 27.4 \\
\hline Oil & 0.6 & 0.9 & 1.4 & 1.9 & 1.0 & 1.6 & 2.1 & 0.6 & 0.9 & 1.3 & 0.6 & 1.1 & 1.8 \\
\hline Gas & 0.0 & 0.0 & 0.0 & 0.0 & 0.0 & 0.0 & 0.0 & 0.5 & 0.9 & 1.3 & 0.7 & 2.2 & 2.9 \\
\hline Electricity & 1.1 & 2.0 & 3.2 & 4.3 & 2.0 & 3.6 & 5.0 & 2.0 & 3.6 & 5.7 & 2.0 & 4.1 & 6.7 \\
\hline $\begin{array}{l}\text { Biomass, } \\
\text { waste and } \\
\text { other } \\
\text { renewables }\end{array}$ & 0.0 & 0.0 & 0.0 & 0.0 & 0.0 & 0.0 & 0.0 & 2.2 & 7.1 & 13.9 & 2.8 & 9.2 & 16.2 \\
\hline
\end{tabular}

India's share of global production is expected to rise sharply from just 6\% in 2007 to approximately $17 \%$ by 2050 as cement consumption declines in OECD regions and peaks in China to subsequently decline in 2030 and 2050. Most of this increase will occur in the short term, with 
consumption increasing by $7.0 \%$ to $7.5 \%$ per year between 2007 and 2015 . India will remain the second-largest producer of cement throughout the period from 2007 to 2050.

Two main differences can be observed between India's Baseline and the BLUE scenarios. The clinkerto-cement ratio in the Baseline Scenario will be about 11\% lower in 2050 than in 2007 and will reach 0.75. In the BLUE Scenario, the ratio will reduce even further to reach about 0.70 in 2050 (Table 9).

Page | 40 The second difference relates to the mix of energy sources used to produce Indian cement. In the Baseline Scenario, the energy mix remains fairly unchanged between 2007 and 2050. In the BLUE Scenario, the share of coal decreases substantially from $85 \%$ in 2007 to about $50 \%$ in 2050 . The use of biomass and alternative fuels will increase to reach almost 30\% of total energy consumption by 2050 .

The energy intensity of India's cement production in the Baseline Scenario improves from the current level of $3.2 \mathrm{GJ} / \mathrm{t}$ cement to $2.7 \mathrm{GJ} / \mathrm{t}$ cement in 2050. However, in the BLUE Scenario lowdemand case, the intensity will be $3.2 \mathrm{GJ} / \mathrm{t}$ cement and for the high-demand case $3.1 \mathrm{GJ} / \mathrm{t}$ cement in 2050. The reason for this is that the lower energy consumption arising from the increased use of clinker substitutes is offset by applying CCS that requires additional energy. As a result, energy use in the BLUE Scenario will be about 15\% higher than in the Baseline Scenario in 2050. But even under the BLUE Scenario, India remains one of the most efficient countries in the world as energy intensity also increases in most other countries.

Figure 16: Cement direct $\mathrm{CO}_{2}$ intensity in India and world average

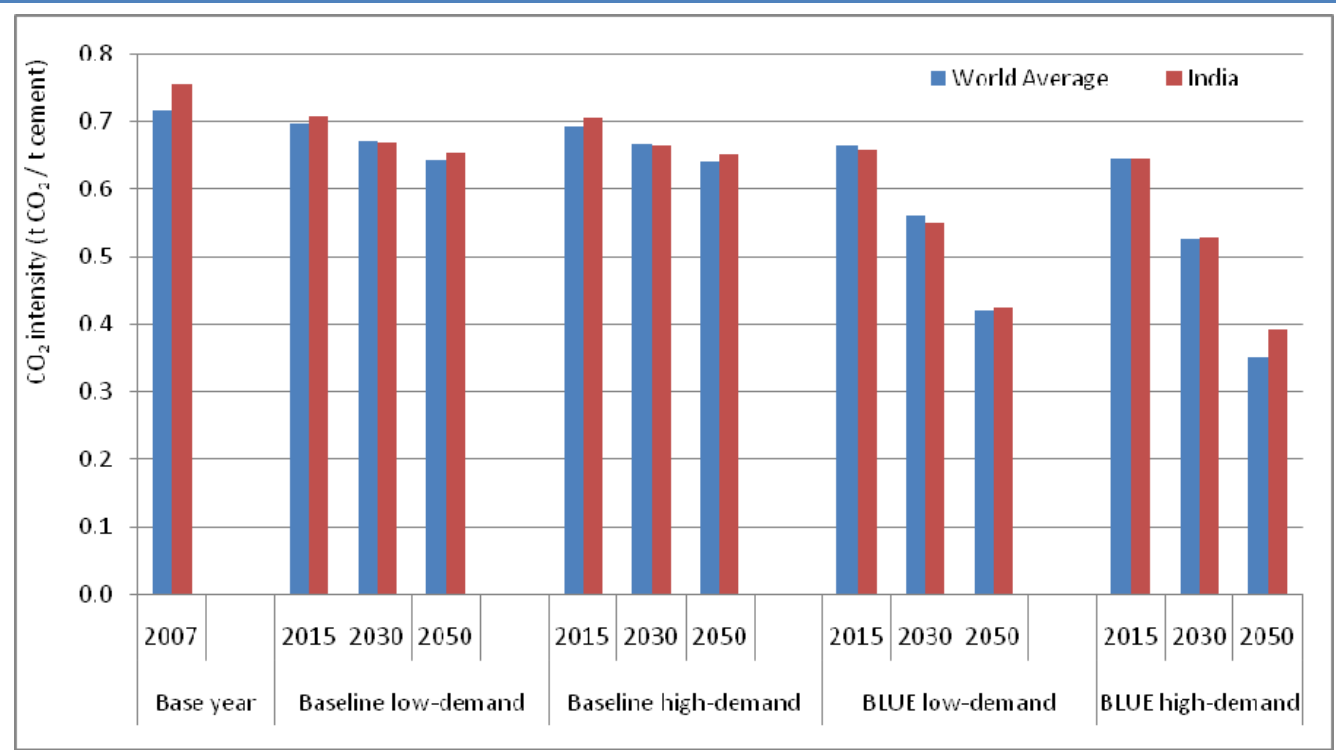

The trend is noticeably different when considering $\mathrm{CO}_{2}$ emissions intensity (Figure 16). In the Baseline Scenario, the trends in $\mathrm{CO}_{2}$ intensity are similar to the trends observed in energy intensity. However, in the BLUE Scenario, the $\mathrm{CO}_{2}$ intensity is $35 \%$ and $40 \%$ lower than in the Baseline Scenario despite the higher energy intensity. The results of the BLUE Scenario are attributable to the change in the fuel mix and the wide application of CCS.

As most energy efficiency improvements are part of the Baseline Scenario, little emissions reduction could be achieved through further efficiency improvements under a BLUE Scenario. It is nevertheless possible for India to reduce its $\mathrm{CO}_{2}$ emissions by $35 \%$ to $40 \%$ below the Baseline Scenario. About $60 \%$ of the reduction comes from the use of CCS and $25 \%$ from the increased use of alternative fuels and other fuel switching (Figure 17). 
Figure 17: India's direct $\mathrm{CO}_{2}$ emissions reduction by technology option for cement

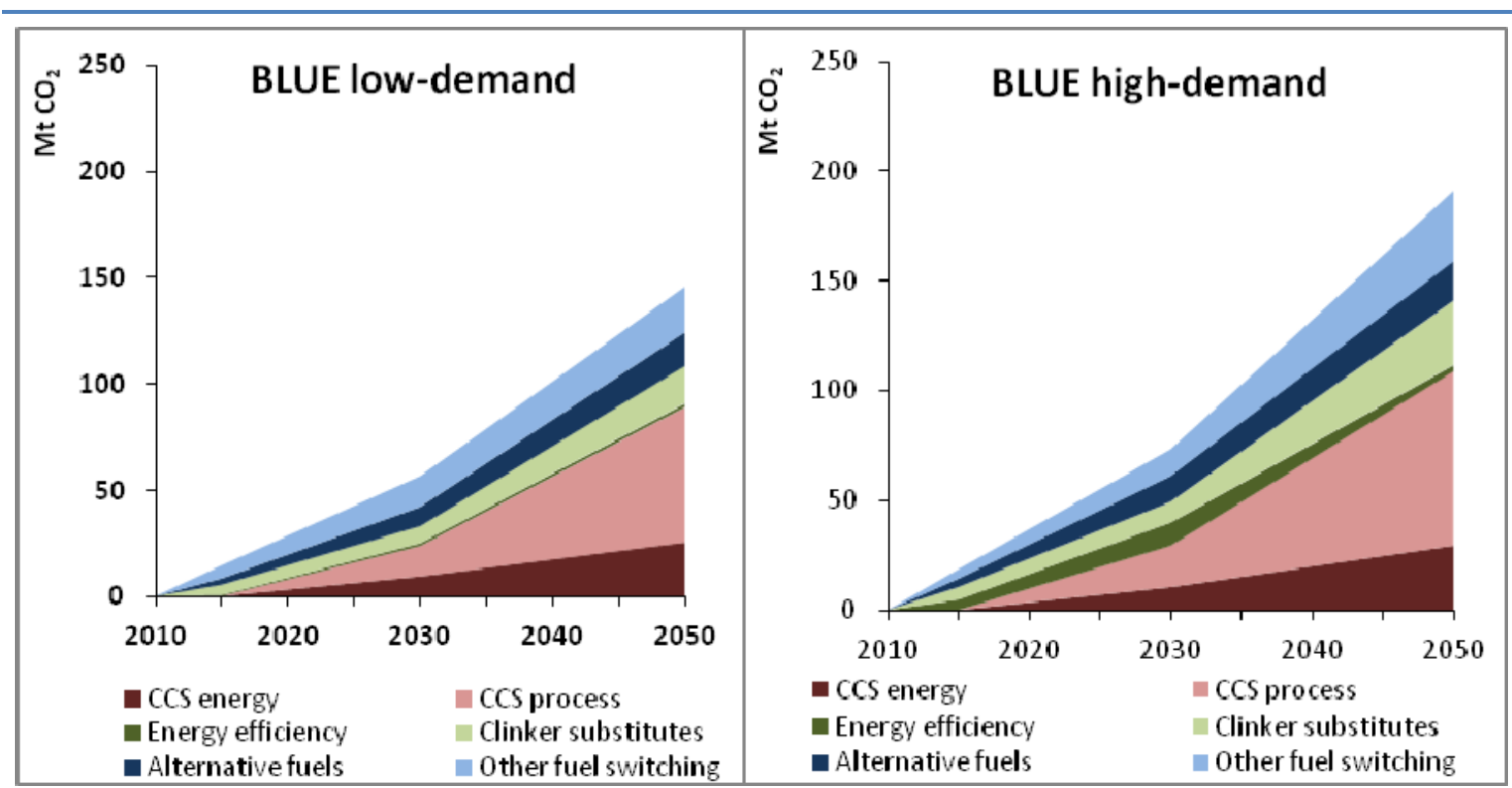

Page | 41

Global cement production is estimated to increase from $2774 \mathrm{Mt}$ in 2007 to $3817 \mathrm{Mt}$ and $4586 \mathrm{Mt}$ in 2050 in the low- and high-demand cases of both scenarios. In both cases, China remains the main cement producer. Between 2007 and 2050, all the growth in cement production will come from non-OECD countries; production from OECD countries will slightly decrease between 2007 and 2050 in the low-demand and increase by only $8 \%$ in the highdemand case, reflecting the fact that many OECD countries are projected to experience a decline in population between 2030 and 2050. Cement production will more than triple between 2007 and 2050 in India and other developing Asia and Africa, with the result that about $45 \%$ of all production in 2050 will be from these countries/regions.

Direct $\mathrm{CO}_{2}$ emissions will continue to rise year-on-year in the Baseline Scenario. In the BLUE Scenario, emissions will also increase in the short run, but at a slower pace than in the Baseline Scenario. By 2050, through greater energy efficiency, increased use of clinker substitutes and alternative fuels, as well as the application of CCS, direct $\mathrm{CO}_{2}$ emissions in 2050 in the BLUE Scenario will be $35 \%$ to $45 \%$ lower than in the Baseline Scenario.

The breakdown of savings in the BLUE Scenario compared to the Baseline Scenario is shown in Figure 18. Efficiency improvements in the BLUE Scenario over and above the Baseline Scenario achieve their maximum effect in 2030 . Thereafter, their contribution to savings declines, as the Baseline Scenario already assumes that most of the available energy efficiency options will have been implemented by 2050. CCS dominates total savings by 2050, accounting for more than half the reduction below the Baseline Scenario by that time. CCS is essential to reduce $\mathrm{CO}_{2}$ emissions below the current level.

The regional trends in $\mathrm{CO}_{2}$ emissions vary considerably, with China, OECD Europe and OECD Pacific seeing their emissions decrease, while India's emissions more than triple. These emission trends are consistent with the production trends. Overall, direct $\mathrm{CO}_{2}$ emissions in 2050 would be $23 \%$ and $47 \%$ higher in the Baseline low- and high-demand cases than in 2007. 
Figure 18: Global direct $\mathrm{CO}_{2}$ emissions reduction by technology option for cement

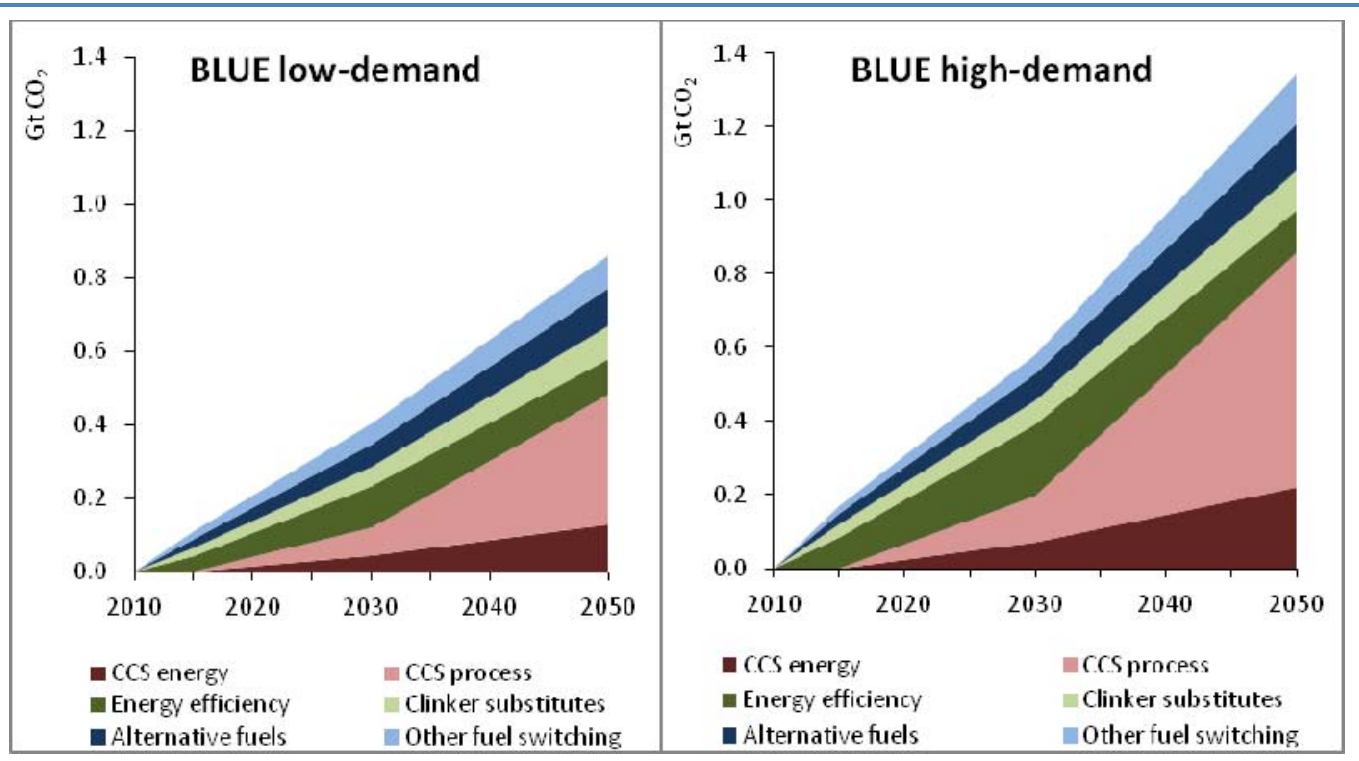

In the BLUE Scenario, emissions peak between 2015 and 2020, and then begin to decline as more efficient and cleaner technologies are introduced. Emissions from OECD countries are expected to be $40 \%$ and $59 \%$ lower than in the Baseline Scenario in 2050. For non-OECD countries, emissions will be $34 \%$ and $43 \%$ lower than the Baseline Scenario. However, given the expected growth rate in the cement production from non-OECD countries and their importance on the global market, they will contribute the most to reducing direct $\mathrm{CO}_{2}$ emissions (Figure 19).

Figure 19: Regional contribution in global direct $\mathrm{CO}_{2}$ emissions in cement, low-demand case

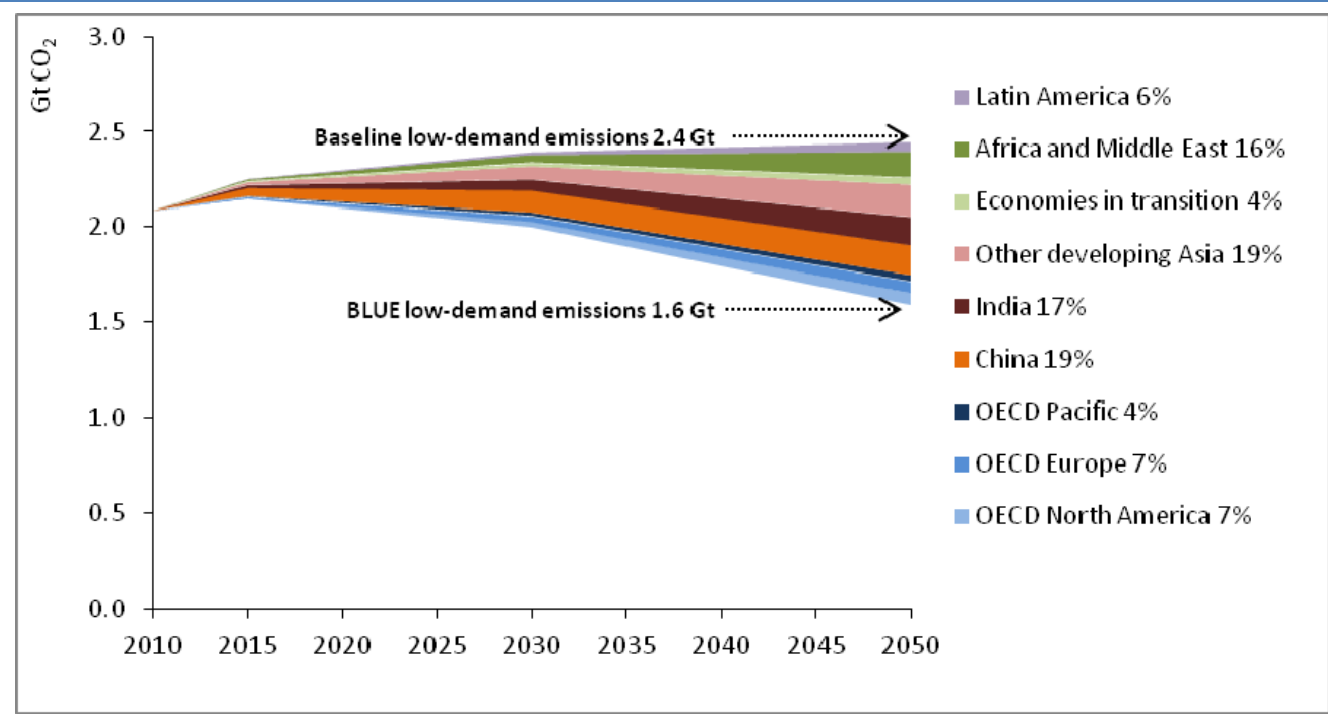

\section{Technology options in the cement sector}

A number of technology options need to be exploited to reduce emissions in the cement sector (Table 10). The four main options for the sector are: increased energy efficiency and improvements in BATs; higher shares of alternative fuel use; the use of greater volumes of clinker substitutes; and deployment of CCS. 
In the case of India, the use of less carbon-intensive fossil fuels and more alternative fossil and biomass fuels are important options for reducing $\mathrm{CO}_{2}$ intensity. Stronger policy support will be needed to reach the levels outlined in the BLUE Scenario. Further reductions in clinker-to-cement ratios will require additional research and development (R\&D) to assess substitution materials and to evaluate regional availability. Developing and implementing international standards for blended cements would also support greater use of clinker substitutes.

Table 10: Technology options for the cement industry

\begin{tabular}{|c|c|c|c|}
\hline Technology & R\&D needs & $\begin{array}{l}\text { Demonstration } \\
\text { needs }\end{array}$ & Deployment milestones \\
\hline \multirow{2}{*}{$\begin{array}{l}\text { Energy efficiency } \\
\text { and shift to BATs }\end{array}$} & \multirow{2}{*}{\multicolumn{2}{|c|}{$\begin{array}{l}\text { Fluidised bed technology } \\
\text { Ongoing further } \\
\text { improvements to BATs }\end{array}$}} & Phase-out of inefficient wet kiln in \\
\hline & & & $\begin{array}{l}\text { small cement plants } \\
\text { International standard for new kilns }\end{array}$ \\
\hline \multirow[t]{2}{*}{ Alternative fuels } & \multirow{2}{*}{\multicolumn{2}{|c|}{$\begin{array}{l}\text { Ongoing identification and classification of suitable } \\
\text { alternative fuels }\end{array}$}} & $\begin{array}{l}\text { Shares in India to rise to between } 22 \% \\
\text { and } 25 \% \text { in } 2030 \text { and } 29 \% \text { by } 2050\end{array}$ \\
\hline & & & $\begin{array}{l}\text { Global shares increase from } 2 \% \text { in } \\
2007 \text { to between } 20 \% \text { and } 22 \% \text { in } \\
2030 \text {, and between } 33 \% \text { and } 34 \% \text { in } \\
2050\end{array}$ \\
\hline \multirow[t]{2}{*}{ Clinker substitutes } & \multicolumn{2}{|c|}{$\begin{array}{l}\text { Analyse substitution material properties and } \\
\text { evaluate regional availability }\end{array}$} & $\begin{array}{l}\text { India clinker-to-cement ratio to reach } \\
0.72 \text { by } 2030 \text { and } 0.69 \text { by } 2050\end{array}$ \\
\hline & \multicolumn{2}{|c|}{$\begin{array}{l}\text { Develop and implement international standards for } \\
\text { blended cements }\end{array}$} & $\begin{array}{l}\text { Global average clinker-to-cement ratio } \\
\text { to reach } 0.72 \text { and } 0.71\end{array}$ \\
\hline \multirow{2}{*}{$\begin{array}{l}\text { CCS post- } \\
\text { combustion } \\
\text { CCS oxyfuelling }\end{array}$} & Pilot plant needed by 2012 & $2015-2020$ & \multirow{2}{*}{$\begin{array}{l}\text { In India, from } 2020,20 \% \text { of all new } \\
\text { large plants equipped with CCS; from } \\
2030,65 \% \text { of all new large plants } \\
\text { equipped with CCS. }\end{array}$} \\
\hline & Gas cleaning & $2020-2030$ & \\
\hline
\end{tabular}

Widespread application of CCS is essential if the cement sector is to reduce $\mathrm{CO}_{2}$ emissions below current levels. In the BLUE Scenario $106 \mathrm{Mt} \mathrm{CO}$ (low-demand case) and $128 \mathrm{Mt} \mathrm{CO}_{2}$ (highdemand case) could be sequestered annually in India in 2050. Reaching these levels implies that CCS will need to be demonstrated at cement plants by 2015 in order to ensure that a number of technology platforms are tested as early as possible. This would be an essential precursor to starting commercial deployment between 2020 and 2025.

\section{Chemicals and petrochemicals}

\section{Overview and context}

The chemical and petrochemical industry in India is dominated by ammonia production for nitrogen fertilisers. The ammonia industry accounts for more than half of the total energy use in the chemical and petrochemical sector. The industry has been sheltered from global competition due to a national self-sufficiency policy and subsidised production. However, India lacks the necessary gas reserves that would be the basis of the same production elsewhere. Therefore in contrast to the rest of the world, oil feedstock plays an important role in ammonia production in India, accounting for more than 50\% of all feedstock use in 2007 in the Indian chemical and petrochemical industry. It should be noted that this share is rapidly declining in favour of gas due to the current high oil prices. Recent offshore gas discoveries may also favour a switch to gas. India's average energy use per tonne of ammonia was $37.5 \mathrm{GJ} / \mathrm{t}$ in 2007 , compared to $28 \mathrm{GJ} / \mathrm{t}$ for the best available gas-based technology. About half of the gap can be attributed to the oil feedstock use. 
Petrochemical production in India is relatively small. The production capacity for ethylene amounted to $3.2 \mathrm{Mt}$ in 2007, $13 \%$ ethane based, 9\% propane based and $78 \%$ naphtha based. Ethane and propane crackers tend to be less energy efficient than naphtha crackers. Chlorine production amounted to $1.7 \mathrm{Mt}$ in 2003/04, 29\% of which is based on the less energy efficient mercury process and the other $71 \%$ based on the membrane process. Soda ash production amounted to $2.2 \mathrm{Mt}$ in 2003/04 (TERI, 2006). High-value chemicals (HVC) production amounted to $10.4 \mathrm{Mt}$ in 2007 . India is the second-largest producer of ammonia with a production of 13.4 Mt, which accounts for $8 \%$ of global production.

Globally, the use of energy and feedstock in the chemical and petrochemical sector accounted for approximately $10 \%$ of worldwide final energy demand in 2007 , equivalent to $880 \mathrm{Mtoe} .{ }^{11}$ It is the largest energy-consuming sector in industry, accounting for approximately $30 \%$ of the total industrial final energy demand. The process energy requirements of the chemical and petrochemical sector generated approximately $1.3 \mathrm{Gt} \mathrm{CO}_{2}$, excluding indirect emissions from electricity use and from the treatment of post-consumer waste (for example, from the incineration of plastics).

It is difficult to measure the physical production of the organic chemical industry given the large number of intermediate products that are traded at all levels of production. Some information is, however, available for some products. Polymer production represents both the largest and the fastest-growing segment of the chemical and petrochemical sector, representing approximately $75 \%$ of the total physical production and rising nearly $6 \%$ per year to approximately $300 \mathrm{Mt}$ in 2006 (PlasticsEurope, 2008; SRI Consulting, 2008). While growth has levelled off in some industrialised countries, polymer production in China and some other emerging economies has continued to increase rapidly. However, worldwide growth has been negatively affected by the recent global economic turmoil.

\section{Technology and energy consumption in the chemical and petrochemical sector}

Given the scale of most chemical and petrochemical plants, it is more appropriate to analyse potential improvements in energy efficiency by referring to the most advanced technologies that are currently in use at industrial scale, in other words best practice technology (BPT). BPT is generally, by definition, economically viable.

The potential to improve energy efficiency in the chemical and petrochemical sector is established by comparing fuel use (including steam) statistics from the IEA energy balance with the BPT values for each of the 57 processes covered (these values, covering 66 products, are provided in Annex B). ${ }^{12}$ The values for the most important chemicals (olefins, aromatics, ammonia and several intermediates) come from an analysis of the BPTs in Europe (Schyns, 2006), rather than world wide (worldwide BPT values are not available). ${ }^{13}$

Energy improvement potential for the chemical and petrochemical sector is shown in Table 11. Process energy and feedstock uses are combined in this analysis to remove the uncertainties caused by different countries adopting different definitions for the individual components in their

\footnotetext{
${ }^{11}$ Final process energy is the total demand for fuel (excluding feedstock energy), steam use and electricity. Final energy is the sum of final process energy and feedstock energy.

12 Steam cracking and aromatics extraction are counted as one process each. Methanol production from natural gas and coal is counted as two processes. Ammonia production from natural gas, oil and coal is counted as three processes. The production of resins, fibres and rubber products are counted as individual processes.

${ }^{13}$ Synthetic rubber is an exception: for confidentiality reasons the BPT data used refer to the global situation, but not to Europe.
} 
energy statistics. The values shown are subject to several uncertainties (see IEA 2009d, pages 21 to 25 for details on the potential data issues). Additional uncertainty may derive from the production data used. ${ }^{14}$

Given the quality of the data, these figures are no more than an indication of actual energy savings potential. They are not robust enough to provide a basis either for target setting or for country comparisons. They can, however, provide valuable information on trends in the industry's efforts to improve energy efficiency. Using this approach would suggest that the minimum theoretical global energy use for the 57 processes, if all plants were to adopt BPTs, is 645 Mtoe. Actual energy use in 2006 according to energy statistics was 753 Mtoe. This suggests an energy savings potential of around 108 Mtoe.

Table 11: Potential energy improvements by BPT in the global chemical and petrochemical sector, 2006 (including both process energy and feedstock use) ${ }^{a}$

\begin{tabular}{|c|c|c|c|c|c|c|c|c|}
\hline & \multicolumn{4}{|c|}{$\begin{array}{l}\text { Final process energy and feedstock use } \\
\text { (including electricity) }\end{array}$} & \multicolumn{4}{|c|}{$\begin{array}{l}\text { Final process energy and feedstock use } \\
\text { (excluding electricity) }\end{array}$} \\
\hline & $\begin{array}{c}\text { Reported } \\
\text { energy use } \\
\text { (Mtoe/yr) }\end{array}$ & $\begin{array}{c}\text { BPT } \\
\text { energy } \\
\text { use } \\
\text { (Mtoe/yr) }\end{array}$ & EEI & $\begin{array}{l}\text { Improvement } \\
\text { potential }\end{array}$ & $\begin{array}{c}\text { Reported } \\
\text { energy use } \\
\text { (Mtoe/yr) }\end{array}$ & $\begin{array}{l}\text { BPT energy } \\
\text { use (Mtoe/yr) }\end{array}$ & EEI & $\begin{array}{l}\text { Improvement } \\
\text { potential }\end{array}$ \\
\hline United States & 174.9 & 135.1 & 0.77 & 0.227 & 153.1 & 117.7 & 0.77 & $23.10 \%$ \\
\hline China & 127.1 & 127.4 & 1 & $(-0.2 \%)$ & 102.7 & 107.8 & 1.05 & $(-5.0 \%)$ \\
\hline Japan & 53.8 & 46.8 & 0.87 & 0.13 & 49.0 & 43.0 & 0.88 & $12.30 \%$ \\
\hline Korea & 37.3 & 38.1 & 1.02 & $(-2.1 \%)$ & 33.8 & 35.3 & 1.04 & $(-4.3 \%)$ \\
\hline Saudi Arabia & 32.7 & 25.3 & 0.77 & 0.227 & 32.7 & 25.3 & 0.77 & $22.70 \%$ \\
\hline Germany & 29.6 & 28.9 & 0.97 & $2.6 \%)$ & 25.4 & 25.5 & 1 & $(-0.3 \%)$ \\
\hline India & 26.2 & 27.1 & 1.03 & $(-3.3 \%)$ & 26.2 & 27.1 & 1.03 & $(-3.3 \%)$ \\
\hline Benelux & 26.1 & 27.4 & 1.05 & $(-5.1 \%)$ & 24.0 & 25.7 & 1.07 & $(-7.3 \%)$ \\
\hline Taiwan & 20.5 & 17.6 & 0.86 & 0.141 & 17.6 & 15.3 & 0.87 & $13.10 \%$ \\
\hline Canada & 20.1 & 18.3 & 0.91 & 0.092 & 18.5 & 17.0 & 0.92 & $8.20 \%$ \\
\hline France & 17.1 & 15.1 & 0.88 & 0.116 & 15.0 & 13.4 & 0.9 & $10.50 \%$ \\
\hline Brazil $^{\text {b }}$ & 15.5 & 13.8 & 0.88 & 0.115 & 13.7 & 12.3 & 0.9 & $10.40 \%$ \\
\hline Italy & 10.9 & 9.7 & 0.89 & 0.107 & 9.3 & 8.5 & 0.91 & $9.10 \%$ \\
\hline World & 841.1 & 715.1 & 0.85 & 0.15 & 753.1 & 644.6 & 0.86 & $14.40 \%$ \\
\hline
\end{tabular}

Notes: a. Assuming an energy coverage of $95 \%$ (see note b). This estimate needs further validation. b. In the case of Brazil, the production of bioethanol is not accounted for because of data limitations. EEI: Energy Efficiency Index.

Sources: Chemweek, 2007a,b,c,d; IEA, 2008b and c; IFA, 2009; RFA, 2009; SRI Consulting, 2008; USGS, 2008a and b; IEA estimates.

Ammonia and methanol are most commonly produced from natural gas; the BPT values for this feedstock are used for all countries with the exception of India and China where coal and oil are also widely used as feedstock. The negative improvement potential calculated for China and India derives from the decision to base BPTs on coal and oil feedstock for ammonia and methanol production in those countries. However, if BPTs were based on the use of natural gas, as for other countries, India would still show a negative improvement potential of $0.4 \%$. This suggests that the choice of feedstock

\footnotetext{
${ }^{14}$ Production data for all organic chemicals and polymers (except for polycarbonate) are taken from SRI Consulting (2008). For most of the inorganic and polycarbonate production, volumes are taken from Chemweek (2007a,b,c,d). Production volumes of other inorganics are taken from USGS (2008a, b). Ethanol production data are taken from Renewable Fuels Association (RFA, 2009) and the International Fertilizers Association (IFA, 2009) provided the production volumes for urea.
} 
is not the only problem with the data. The negative improvement potential may partly be caused by erroneous production statistics and/or erroneous energy statistics also in other countries.

\section{Best practice technology and technical savings potential}

Page | 46 This analysis presented in Table 11 reports the energy savings that would be achieved by implementing BPT only in core chemical processes. There are further opportunities within the sector for achieving energy savings in the short to medium term. As discussed in more detail in an IEA Information Paper (IEA, 2009d), process intensification/integration, combined heat and power (CHP), recycling and energy recovery all offer opportunities for reducing the industry's energy use and $\mathrm{CO}_{2}$ emissions.

The total worldwide potential savings from these measures and from applying BPTs is approximately 235 Mtoe in final energy and approximately 290 Mtoe in primary energy use (Figure 20). Regional potentials based on this methodology vary significantly. In the case of India, the potentials are estimated to be 6.6 Mtoe in final energy.

Figure 20: Energy savings potential in 2007 for chemicals and petrochemicals, based on BPT

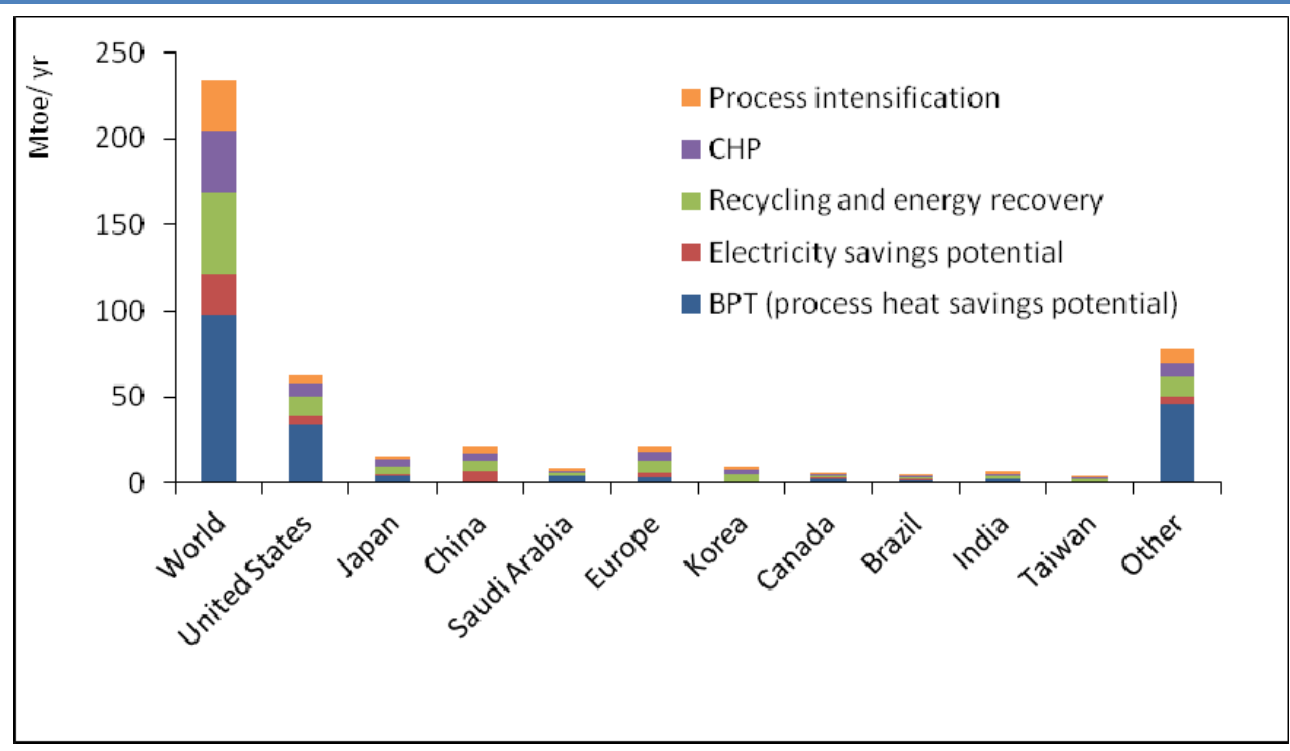

Note: Europe includes Benelux, France, Germany, Italy and the United Kingdom. No BPT energy savings potential is shown for those countries with apparently negative improvement potential.

\section{Scenario results}

Consumption of HVC in India is low compared to the world average. In 2007, HVC consumption was $9.3 \mathrm{~kg} / \mathrm{cap}$ while the world average was $43 \mathrm{~kg} / \mathrm{cap}$. In the Baseline Scenario, HVC production in India is projected to increase from $10 \mathrm{Mt}$ in 2007 to $45 \mathrm{Mt}$ in the low-demand case and $80 \mathrm{Mt}$ in the high-demand case. This increase will be fully met by the primary production of chemicals. However, in the BLUE Scenario, recycling of post-consumer plastic waste will reduce the need for HVC production (Table 12), explaining the lower production in this scenario. In the BLUE Scenario, India's HVC production is estimated to increase to $39 \mathrm{Mt}$ (low-demand) and $59 \mathrm{Mt}$ (highdemand). In both scenarios, India will be one of the top-five HVC producers in 2050.

Per-capita consumption of ammonia in India remained relatively stable in the past few years and, in 2007, was about half the world average. Production in India is projected to increase at a higher 
rate between 2007 and 2050 than in the last decade, increasing by $126 \%$ (17 Mt) in the lowdemand case and increasing 2.5 times (20 Mt) in the high-demand case. In 2050, India will rank among the top-three ammonia producers in the world. Production of methanol will still be small, but will increase 10 times between 2007 and 2050.

Table 12: India's HVC, ammonia and methanol production

\begin{tabular}{|l|c|c|c|c|c|c|c|c|c|c|c|c|c|}
\hline & & \multicolumn{3}{|c|}{$\begin{array}{c}\text { Baseline } \\
\text { low-demand }\end{array}$} & \multicolumn{3}{c|}{$\begin{array}{c}\text { Baseline } \\
\text { high-demand }\end{array}$} & \multicolumn{3}{c|}{$\begin{array}{c}\text { BLUE } \\
\text { low-demand }\end{array}$} & \multicolumn{3}{c|}{$\begin{array}{c}\text { BLUE } \\
\text { high-demand }\end{array}$} \\
\hline & $\mathbf{2 0 0 7}$ & $\mathbf{2 0 1 5}$ & $\mathbf{2 0 3 0}$ & $\mathbf{2 0 5 0}$ & $\mathbf{2 0 1 5}$ & $\mathbf{2 0 3 0}$ & $\mathbf{2 0 5 0}$ & $\mathbf{2 0 1 5}$ & $\mathbf{2 0 3 0}$ & $\mathbf{2 0 5 0}$ & $\mathbf{2 0 1 5}$ & $\mathbf{2 0 3 0}$ & $\mathbf{2 0 5 0}$ \\
\hline Ethylene & 3 & 5 & 10 & 18 & 6 & 16 & 31 & 5 & 9 & 16 & 6 & 14 & 25 \\
\hline Propylene & 2 & 3 & 6 & 10 & 4 & 9 & 19 & 3 & 5 & 9 & 4 & 8 & 13 \\
\hline BTX & 5 & 6 & 10 & 17 & 7 & 15 & 29 & 6 & 9 & 15 & 7 & 13 & 20 \\
\hline Total HVC & $\mathbf{1 0}$ & $\mathbf{1 5}$ & $\mathbf{2 5}$ & $\mathbf{4 5}$ & $\mathbf{1 8}$ & $\mathbf{4 0}$ & $\mathbf{8 0}$ & $\mathbf{1 5}$ & $\mathbf{2 3}$ & $\mathbf{3 9}$ & $\mathbf{1 7}$ & $\mathbf{3 4}$ & $\mathbf{5 9}$ \\
\hline Ammonia & 13 & 17 & 24 & 30 & 19 & 26 & 33 & 17 & 24 & 30 & 19 & 26 & 33 \\
\hline Methanol & 0.1 & 0.2 & 0.4 & 0.8 & 0.2 & 0.5 & 1.0 & 0.2 & 0.4 & 0.8 & 0.2 & 0.5 & 1.0 \\
\hline
\end{tabular}

Note: BTX: Benzene, Toluene, Xylene.

Sources: SRI Consulting, 2008; IEA analysis.

Between 2007 and 2050, driven by the strong growth in the chemical and petrochemical production, energy use in the Baseline Scenario will increase from 27 Mtoe to 83 Mtoe (low-demand case) and 126 Mtoe (high-demand case). Oil continues to dominate, accounting for $75 \%$ and $81 \%$ of the total consumption in 2050 (Figure 21). About three-quarters of the oil is used as feedstock.

In the BLUE Scenario, energy consumption will increase to only 74 Mtoe (low-demand case) and 100 Mtoe (high-demand case) in 2050, as greater energy efficiency will help to reduce energy intensity. The significant change in the energy mix is another factor explaining the lower energy consumption. Natural gas will gradually replace oil as a feedstock: as gas-based technologies are more efficient than oil-based ones, this change will help to reduce energy use. The BLUE Scenario also assumes the use of biomass and waste, which will account for $4 \%$ and $7 \%$ of total energy use by 2050 .

Figure 21: India's chemical and petrochemical sector energy consumption, including feedstock

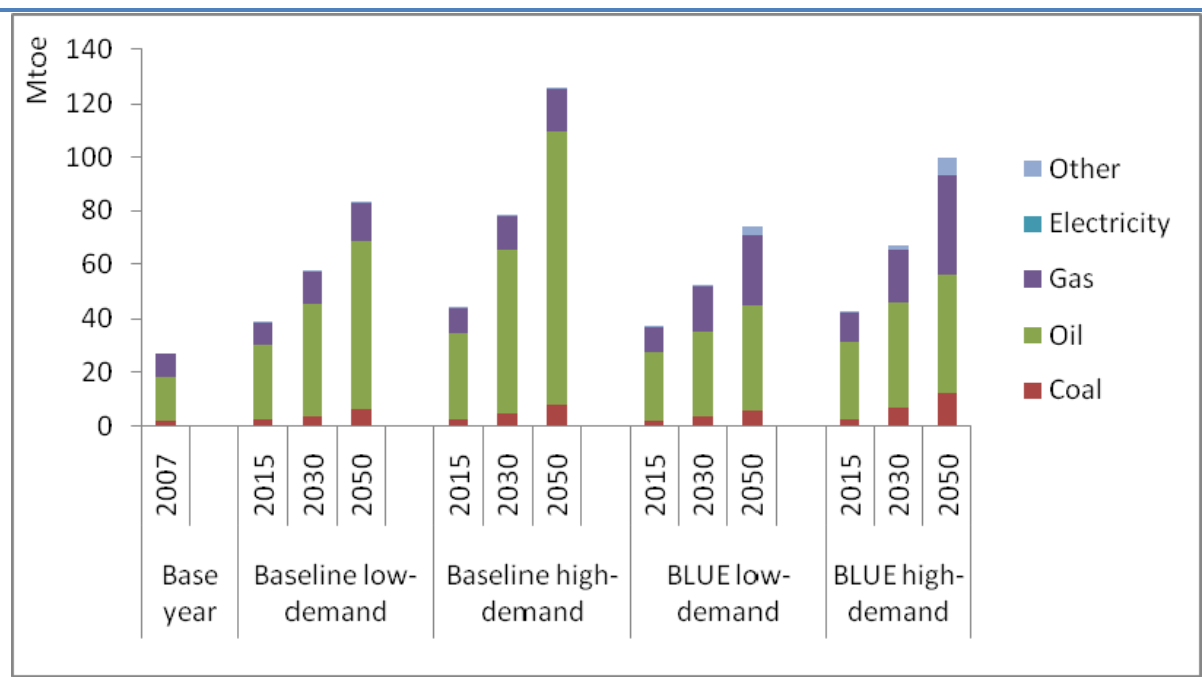

Overall, total energy use in 2050 will be $11 \%$ and $20 \%$ lower in the low- and high-demand cases of the BLUE Scenario than in the Baseline Scenario. 
Between 2007 and 2050 in the Baseline Scenario, total direct emissions from chemicals and petrochemicals rise by $176 \%$ to $132 \mathrm{Mt} \mathrm{CO}_{2}$ (low-demand) and by $261 \%$ to $173 \mathrm{Mt} \mathrm{CO}_{2}$ (high-demand).

In the BLUE Scenario, direct $\mathrm{CO}_{2}$ emissions reach $68 \mathrm{Mt} \mathrm{CO}_{2}$ (low-demand) and $77 \mathrm{Mt} \mathrm{CO}$ (highdemand) in 2050. While emissions are still $42 \%$ and $61 \%$ higher than 2007 levels, they are $48 \%$ and 55\% lower than in the Baseline Scenario. In both the low- and high-demand cases, energy efficiency is the main contributor in reducing direct emissions in this sector, accounting for more than $40 \%$ of the reduction (Figure 22 ).

Figure 22: India's direct $\mathrm{CO}_{2}$ emissions reduction by technology option for chemicals and petrochemicals

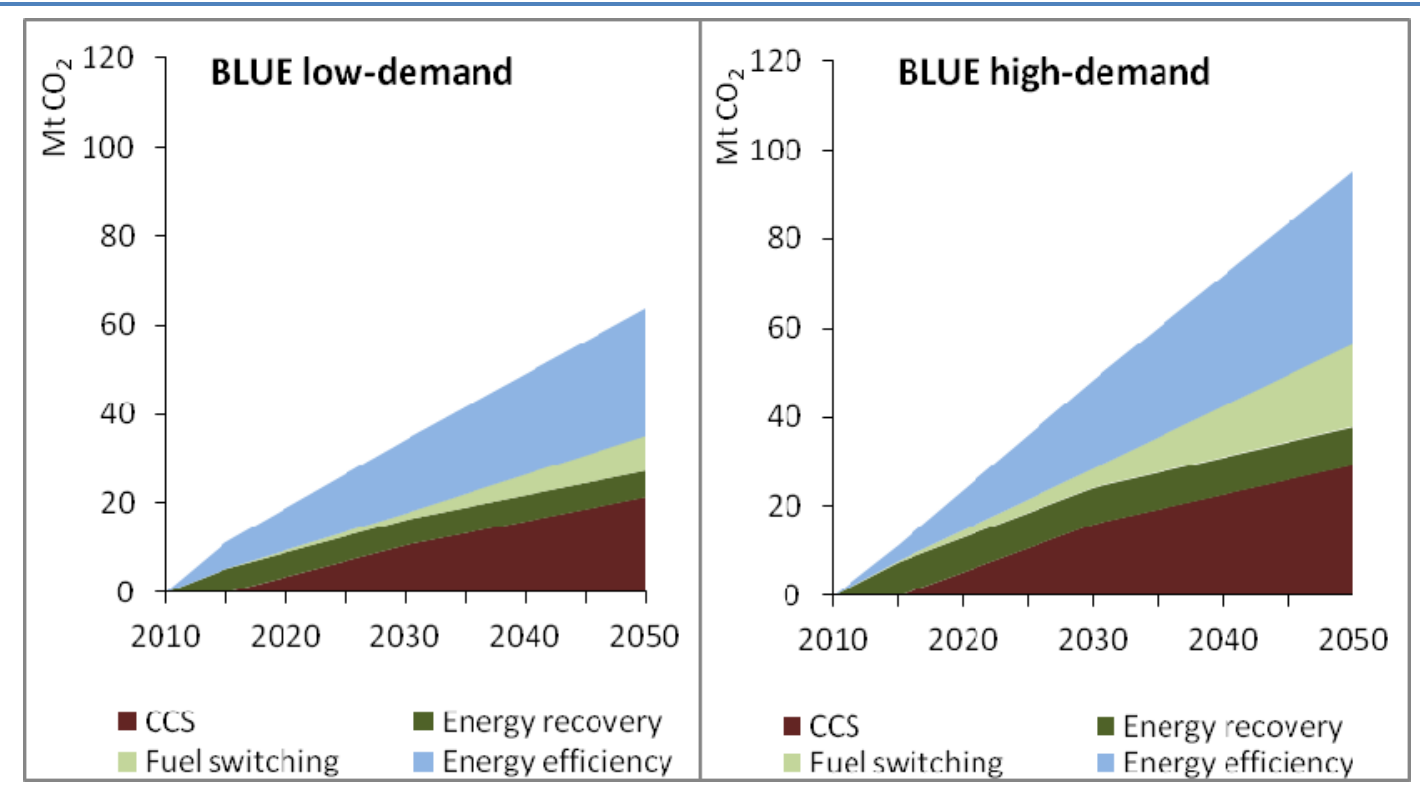

CCS is also a key option in the BLUE Scenario, accounting for one-third of emissions reduction by 2050. Fuel switching, although modest in the short term, will play an increasingly important role and will account for $13 \%$ to $19 \%$ of the emissions reduction in 2050 .

Global production of HVCs is projected to grow by $8 \mathrm{Mt}$ to $14 \mathrm{Mt}$ a year from 2007 to 2050, similar to the $10 \mathrm{Mt}$ annual growth from 1990 to 2005. Compared to the current rate, HVC production in 2050 is $330 \mathrm{Mt}$ and $600 \mathrm{Mt}$ higher in the Baseline Scenario low- and high-demand cases. This increase is smaller, $245 \mathrm{Mt}$ and $340 \mathrm{Mt}$, in the BLUE Scenario low- and high-demand cases as higher recycling rates reduce the need for HVC production. Ammonia production will rise at a higher rate between 2007 and 2050 than in the last decade, increasing by $63 \%$ in the lowdemand case and almost doubling in the high-demand case.

In the BLUE Scenario, emissions in 2050 are about $7 \%$ lower than 2007 levels, and 52\% and 59\% lower than the Baseline Scenario levels for 2050. The largest reduction in direct $\mathrm{CO}_{2}$ emissions in the BLUE Scenario comes from energy efficiency improvements (Figure 23). These save an estimated $735 \mathrm{Mt} \mathrm{CO}_{2}$ in the low-demand case and $935 \mathrm{Mt} \mathrm{CO}_{2}$ in the high-demand case in 2050. In the BLUE Scenario high-demand case, fuel switching reduces emissions by $200 \mathrm{Mt} \mathrm{CO}_{2}$ in 2050, although in the BLUE Scenario low-demand case it saves only $85 \mathrm{Mt} \mathrm{CO}$. CCS accounts for savings of $265 \mathrm{Mt} \mathrm{CO}$ and $310 \mathrm{Mt} \mathrm{CO}_{2}$ in 2050 in the BLUE Scenario low- and high-demand cases respectively. 
Figure 23: Global direct emissions reduction by technology option for chemicals and petrochemicals

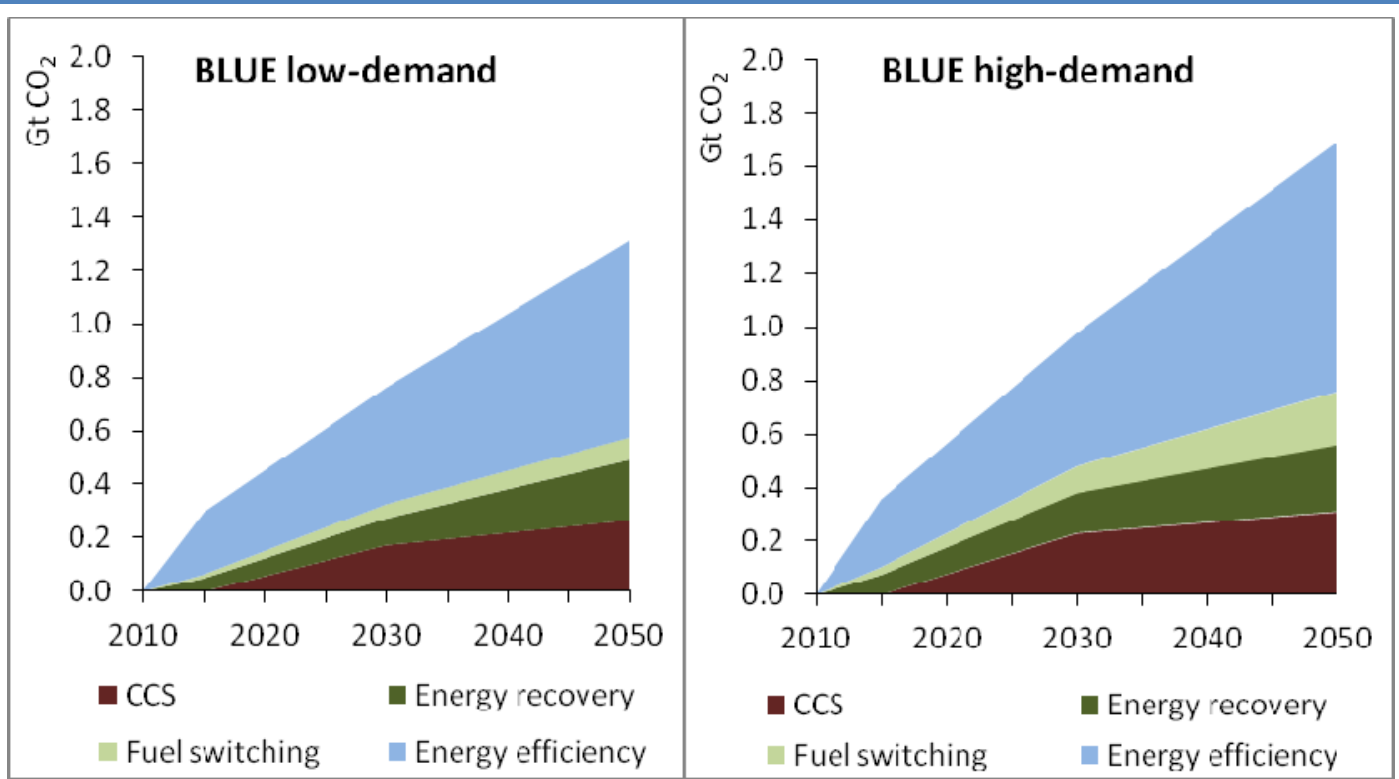

Page | 49

In the Baseline Scenario, regional emissions grow fastest in Asia, and Africa and the Middle East with emissions in these regions seeing an increase of three times the current rate. Emissions in OECD Europe and OECD Pacific will decline slightly. Given the strong growth in HVC production expected in Africa and Middle East, these regions will contribute the most to reducing $\mathrm{CO}_{2}$ emissions from the Baseline Scenario (Figure 24). Their emissions, however, will still increase by 84\% between 2007 and 2050 in the BLUE Scenario low-demand case.

The move away from coal and, to a lesser extent, oil feedstock explains, in part, China's large contribution to the overall emissions reduction.

Figure 24: Regional contribution to reducing global direct $\mathrm{CO}_{2}$ emissions in chemicals and petrochemicals, low-demand case

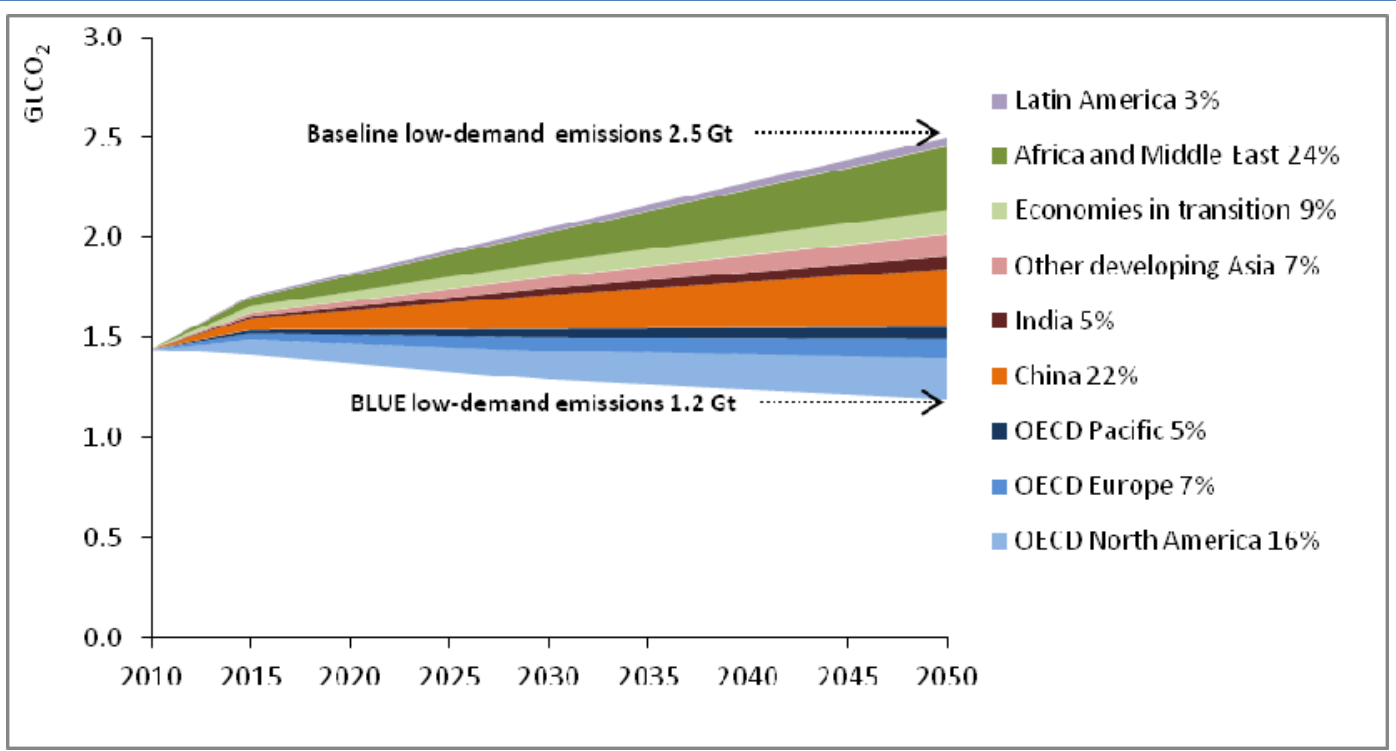




\section{Technology options in the chemical and petrochemical sector}

Implementing BPT in the short term and new technologies in the long term would enable the sector to reduce significantly both its energy needs and its $\mathrm{CO}_{2}$ intensity. A wide range of technology options needs to be applied in order to reach the emissions levels implicit in the BLUE Scenario. Ambitious R\&D, spanning basic and applied research, followed by strong and effective technological developments are needed to reach these goals. New developments in catalysts, membranes and other separation processes, process intensification and bio-based chemicals could lead to substantial energy savings. All countries should strive to achieve BPT levels by 2050. New technologies will need to be brought on stream from 2020 onwards. A number of technological goals will need to be met if the chemical and petrochemical sector is to meet its full potential in reducing $\mathrm{CO}_{2}$ emissions (Table 13).

Table 13: Technology options for the chemical and petrochemical industry

\begin{tabular}{|c|c|c|c|}
\hline Technology & R\&D needs & $\begin{array}{l}\text { Demonstration } \\
\text { needs }\end{array}$ & Deployment milestones \\
\hline $\begin{array}{l}\text { New olefin } \\
\text { production } \\
\text { technologies }\end{array}$ & $\begin{array}{l}\text { Improve methanol-to-olefin } \\
\text { (MTO) processes and } \\
\text { oxidative coupling of methane } \\
\text { (OCM) }\end{array}$ & & $\begin{array}{l}\text { Currently under way with greater } \\
\text { penetration from } 2020\end{array}$ \\
\hline $\begin{array}{l}\text { Other catalytic } \\
\text { processes }\end{array}$ & $\begin{array}{l}\text { Improve performance and } \\
\text { further reduce gap to } \\
\text { thermodynamically optimal } \\
\text { catalytic process by } 65 \% \text { to } \\
80 \%\end{array}$ & Under way & Starting in 2020 to 2025 \\
\hline Membranes & $\begin{array}{l}\text { Develop other novel } \\
\text { separation technologies }\end{array}$ & & $\begin{array}{l}\text { Expand use of membrane } \\
\text { separation technologies }\end{array}$ \\
\hline $\begin{array}{l}\text { Bio-based } \\
\text { chemicals and } \\
\text { plastics }\end{array}$ & Develop bio-based polymers & Bio-based monomers & $\begin{array}{l}\text { Wider use of bio-based feedstock } \\
\text { from } 2025 \\
\text { For India, share increase to } 4 \% \\
\text { and } 7 \% \text { in } 2050 \\
\text { Global share will increase to } 8 \% \\
\text { and } 10 \% \text { in } 2050 .\end{array}$ \\
\hline CCS for ammonia & & Two plants by 2012 & $\begin{array}{l}20 \text { plants by } 2020 \text { and } 50 \text { plants by } \\
2030 \\
\text { In India, } 40 \% \text { of new plants built } \\
\text { between } 2015 \text { and } 2030 \text { and } \\
\text { equipped with CCS; } 75 \% \text { of new } \\
\text { plants built between } 2030 \text { and } \\
2050 \text { equipped with CCS }\end{array}$ \\
\hline
\end{tabular}

Note: MTO is methanol to olefin and OCM is oxidative coupling of methanol.

Any new investments made in coming years are likely to remain in use for decades. As companies invest they will make fundamental, and in many cases, irreversible choices about feedstock. First-of-a-kind large-scale plants for the production of bio-based chemicals and plastics are currently being built. The experience gained by these plants and their products in the next 10 to 20 years will determine, to a large extent, the success or failure of bio-based chemicals and plastics. Policy support needs to extend over relatively long periods in order to be successful. Designing suitable and affordable policies for bio-based chemicals and plastics is a challenge given the complexity of the sector and its products, international trade agreements and the need to avoid displacing food production.

R\&D on materials development and adapted design techniques that can, for example, maximise material efficiency and facilitate disassembly and separation is necessary so that the potential for recycling can be fully exploited. Strong policy support is needed in order to expand collection schemes. A portfolio of mechanical and chemical recycling steps, followed by highly efficient incineration with energy recovery can increase recycling. 


\section{Pulp and paper}

\section{Overview and context}

India's paper and paperboard production increased from 2.2 Mt in 1990 to $7.6 \mathrm{Mt}$ in 2007; an increase of about $7.5 \%$ per year. Pulp production totalled $4.0 \mathrm{Mt}$ in 2007 , an increase of $5 \%$ per year since 1990 . Over the same period, recovered paper use has increased by $8 \%$ per year, from $0.23 \mathrm{Mt}$ to $0.85 \mathrm{Mt}$. The significant increase over the past few years reflects efforts made by national and local governments and large paper companies to develop more efficient collection systems (Papermart, 2010). In India the recovery rate works out to about 20\% (IPMA, 2010b), which is low by international standards.

India's pulp and paper industry is characterised by a high share of small- and medium-sized paper mills. There are approximately 600 pulp and paper mills, so the average plant has a capacity of less than 15 kilotonnes per year (kt/yr) (Arcot and Belgaumkar, 2008). There are only 25 mills with a capacity of $50 \mathrm{kt} / \mathrm{yr}$ or more (IPMA, 2010b). The mills use a variety of raw materials such as wood, bamboo, recycled fibre, bagasse and wheat straw. About $40 \%$ of India's paper is made from hardwood and bamboo fibre, 30\% from agro-waste and 30\% from recycled fibre (ASSOCHAM, 2010).

It is not economical to install the same energy efficient equipment in a small or medium-sized plant as it is in a large plant. Furthermore, Indian pulp production uses a lot of agricultural residues, which is less efficient than pulp making from wood. The peculiarities of India's paper industry partially explain the lower efficiency of the country's pulp and paper mills compared to the industrialised countries.

Globally, the pulp and paper sector is the fourth-largest industrial sector in terms of energy use, consuming 164 Mtoe of energy in 2007, which is $5 \%$ of total global industrial energy consumption. The primary input for pulp and paper manufacture is wood. The industry therefore usually has ready access to biomass resources and it generates from biomass approximately half of its own energy needs. It also produces energy as a by-product. The majority of the fuel used in pulp and paper making is used to produce heat and just over a quarter to generate electricity.

Table 14: Global paper and paperboard production, 2007

\begin{tabular}{lccc}
\hline & $\begin{array}{c}\text { Paper and paperboard } \\
\text { production }\end{array}$ & $\begin{array}{c}\text { Share } \\
(\%)\end{array}$ & Cumulative production share (\%) \\
\hline United States & 83.8 & 21.7 & 21.7 \\
\hline China & 78.0 & 20.2 & 41.8 \\
\hline Japan & 28.9 & 7.5 & 49.3 \\
\hline Germany & 23.2 & 6.0 & 55.3 \\
\hline Canada & 18.1 & 4.7 & 60.0 \\
\hline Finland & 14.3 & 3.7 & 63.7 \\
\hline Sweden & 11.9 & 3.1 & 66.8 \\
\hline Korea & 10.9 & 2.8 & 69.6 \\
\hline Italy & 10.1 & 2.6 & 72.2 \\
\hline France & 9.9 & 2.6 & 74.7 \\
\hline Other & 97.7 & 25.3 & 100.0 \\
\hline World & 386.9 & 100.0 & \\
\hline
\end{tabular}

Sources: FAOSTAT; IPMA , 2010a. 
Global paper and paperboard production has grown by more than $60 \%$ since 1990 , totalling $387 \mathrm{Mt}$ in 2007. The global paper industry is highly concentrated in the United States, China, Japan, Germany and Canada, which together accounted for $60 \%$ of total paper production in 2007 (Table 14). As recovered paper use has increased, pulp production since 1990 has increased at a slower rate than paper and paperboard production. Pulp production was $192 \mathrm{Mt}$ in 2007, 16\% higher than in 1990. Over the same period, recovered paper more than doubled from $84 \mathrm{Mt}$ in 1990 to $194 \mathrm{Mt}$ in 2007. The six largest pulp-producing countries, the United States, Canada, China, Finland, Sweden and Brazil produced just below 70\% of the world's pulp in 2007.

The large share of biomass use as fuel makes the sector one of the least $\mathrm{CO}_{2}$-intensive, although large variations exist among different countries, depending on biomass availability and industry structure. ${ }^{15}$ The sector emitted $183 \mathrm{Mt}$ of direct $\mathrm{CO}_{2}$ in 2007 , representing only $2 \%$ of direct emissions from the industry.

\section{Technology and energy consumption in pulp and paper production}

Energy is used in the pulp and paper industry in a number of different production processes. The main processes are:

- chemical pulping;

- mechanical pulping;

- paper recycling; and

- paper production.

The main production facilities are either pulp mills or integrated paper and pulp mills. An integrated mill is more energy-efficient than the combination of a stand-alone pulp mill and paper mill because pulp drying can be avoided. But integrated plants require grid electricity as well as additional fuel. Most of the improvements in energy efficiency that have been achieved so far have come from integrated pulp and paper mills in which recovered heat is used in the production process, for example to dry the paper. Investment in heat recovery systems in standalone mechanical pulp mills is not economically viable.

Chemical pulping yields black liquor as a by-product, which can then be processed in a recovery boiler to produce heat and electricity. Roughly $22 \mathrm{GJ}$ of black liquor can be combusted per tonne of pulp. Large modern chemical pulp mills are more than self-sufficient in energy terms, delivering surplus electricity to the grid.

The production of recovered paper pulp uses $10 \mathrm{GJ}$ to $13 \mathrm{GJ}$ less energy per tonne than the production of virgin pulp, depending on whether the recovered paper is de-inked and whether mechanical or chemical pulp is being replaced. Although less energy-intensive, the production of recovered paper pulp is generally more $\mathrm{CO}_{2}$-intensive, as the production of chemical pulp, by using biomass for energy, is $\mathrm{CO}_{2}$-neutral. In many cases, the energy used for the production of recovered paper pulp comes from fossil fuels. As a result, using higher levels of recovered paper can significantly reduce energy intensity in the sector, but at the cost of higher $\mathrm{CO}_{2}$ emissions.

Current levels of recovered paper production are already high in many countries. They vary from $30 \%$ in the Russian Federation to $70 \%$ in Japan. Recycling rates can be increased in most regions, especially in many non-OECD countries where the recovered paper production rate varies from $10 \%$ to $50 \%$. The upper technical limit to waste paper collection is $81 \%$ (CEPI, 2006), but practically the upper limit may be closer to $60 \%$.

\footnotetext{
${ }^{15}$ The combustion of biomass is considered to be carbon-neutral.
} 
The IEA developed an energy efficiency improvement potential index that assesses current performance against BAT. Using IEA energy statistics for final energy use, ${ }^{16}$ a BAT value is derived for each mechanical pulp, chemical pulp ${ }^{17}$ waste paper pulp, de-inked waste paper pulp and seven different paper grades. Multiplying production volumes by this BAT value gives a figure representing the practical minimum energy use. Figures for heat (steam) demand in each country are estimated on the basis of reported fuel consumption in the industry and assume $80 \%$ efficiency for all fuels except for biomass where $70 \%$ efficiency is applied. By dividing this figure by actual energy use (final energy), an energy efficiency index (EEI) is derived, from which the potential for improvement (the extent to which the index falls short of 1.0) can be calculated.

A country's EEI would be 1.0 if the energy used was the same as what it would use if it only adopted BATs. Values below 1.0 indicate that energy consumption is higher than BAT levels and signify an opportunity for greater energy efficiency (Figure 25). Figures above 1.0 could mean that the BAT figures are too conservative or that they give insufficient credit for the relatively high efficiency levels of integrated mills. The figures might also be the result of accounting inconsistencies among countries.

Figure 25: Pulp and paper heat efficiency potentials

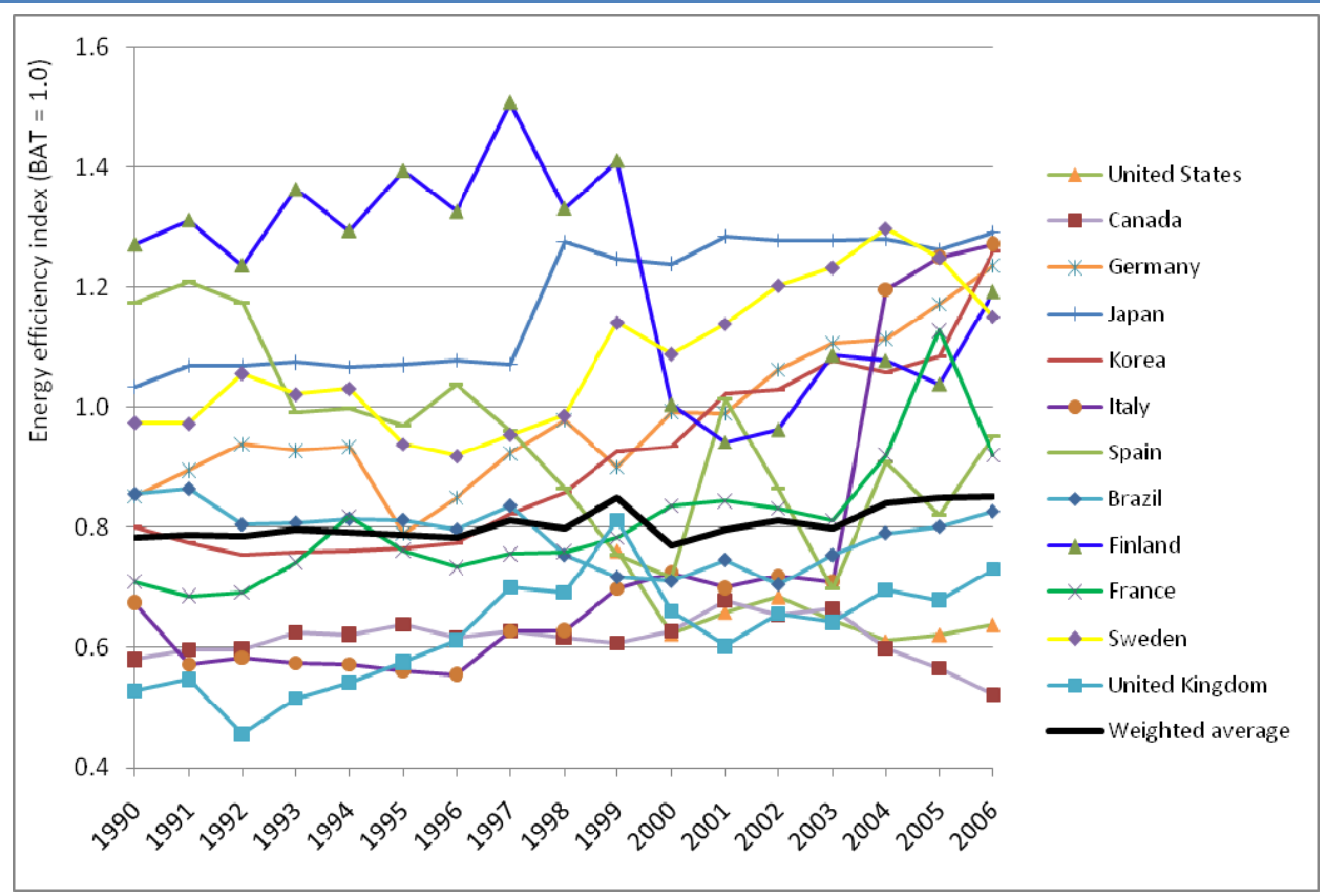

Notes: In 1998, the Ministry of Economy Trade and Industry (METI) (Japan) made significant changes in the way it accounted for energy use in the pulp and paper sector. As a result, Japanese data are no longer consistent with other countries. In Finland, changes of ownership of combined heat and power (CHP) units appear to have resulted in a change in reporting, which has reduced the allocation of fuel use to pulp and paper. In Canada, all biomass used in industry is reported under the pulp, paper and printing sector, leading to a significant over-reporting of energy use. This explains Canada's larger than average potential for improvement in this figure.

The quality of the energy data has made it very difficult to develop reliable indicators for this sector. The indicators analysis has raised a number of questions regarding data comparability and consistency among countries. Reporting methodologies for biomass use seem to vary widely among countries. In the latest statistics submitted to the IEA, a number of countries

\footnotetext{
${ }^{16}$ As IEA statistics also include printing, an adjustment is made to remove energy use for printing on the basis of available energy data from national sources, or estimated by comparing countries with similar industry structure.

${ }^{17}$ A reduction of $2.5 \mathrm{GJ}$ is applied in integrated chemical pulp to reflect the reduced heat requirement for drying pulp.
} 
have significantly revised down their biomass use in the sector compared with earlier submissions. Other countries report no biomass use despite producing chemical pulp, which has black liquor as a by-product. The high level of combined heat and power (CHP) use in the sector combined with different CHP allocation rules for fuel input in countries also contribute to inconsistent energy statistics.

Page | 54

\section{Best available technology and technical savings potential}

The EEls can be used to assess the energy savings that could be achieved by applying BATs or by increasing the use of CHP or recovered paper. However, given the data quality issues the indicators need to be used cautiously.

In the case of India, some mills show very high-energy consumption, compared to international standards. This suggests a significant potential for improving efficiency. Given India's relatively low rate of using recovered paper at just $20 \%$, significant energy savings could be achieved by increasing the amount of recycling. Overall, increased recycling and CHP use, and the application of BATs could lead to estimated potential energy savings of over $20 \%$ on the current level of energy consumption.

Analysis suggests that applying BATs globally could yield total energy savings of 22 Mtoe for heat and electricity use (Figure 26). If global recycling was increased to the current European level of $60 \%$, another 6 Mtoe of energy could be saved. Higher CHP use could achieve an additional saving of approximately 6 Mtoe. Total savings for the sector are estimated at approximately 35 Mtoe, equivalent to $21 \%$ of total current energy use by the sector.

Figure 26: Energy savings potential in 2007 for the pulp and paper, based on BAT

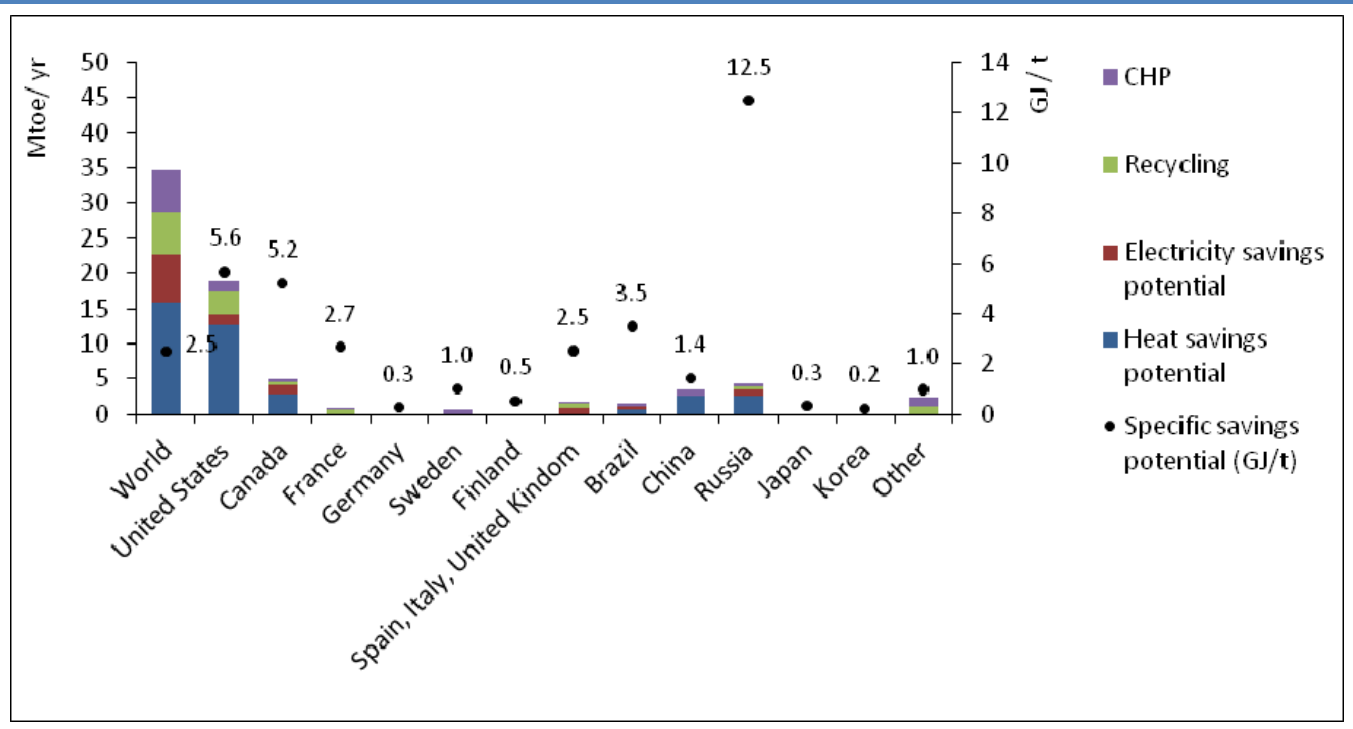

\section{Scenario results}

Current per capita consumption of paper and paperboard in India is among the lowest in the world at just $7.7 \mathrm{~kg} / \mathrm{cap}$ in 2007 compared to an average of $58 \mathrm{~kg} / \mathrm{cap}$ for the world. As India's GDP rises, per capita paper consumption is expected to rise to between $43 \mathrm{~kg} / \mathrm{cap}$ and $76 \mathrm{~kg} / \mathrm{cap}$ in 2050. India's share of the global paper and paperboard market will rise from just $2 \%$ today to 
approximately $10 \%$ and $13 \%$ in 2050 . India is set to become among the top-three producers of paper and paperboard globally.

While paper and paperboard production is assumed to be the same in the Baseline and BLUE Scenario, the use of recovered paper in India will be more than $25 \%$ higher in the BLUE Scenario than in the Baseline scenarios in 2050. This growth in recovered paper will reduce the need for pulp production from virgin fibres. This change in the production process will result in energy intensity improvements. However, the production of recovered paper pulp is generally more $\mathrm{CO}_{2}$ intensive than the production of chemical pulp, as the latter uses biomass for energy, which is $\mathrm{CO}_{2}$-neutral. In many cases, the energy used for the production of recovered paper pulp comes for fossil fuels. As a result, using higher levels of recovered paper can significantly reduce energy intensity in the sector, but at the cost of higher $\mathrm{CO}_{2}$ emissions.

Table 15: India's pulp and paper production by scenarios

\begin{tabular}{|c|c|c|c|c|c|c|c|c|c|c|c|c|c|}
\hline & \multirow[t]{2}{*}{2007} & \multicolumn{3}{|c|}{$\begin{array}{c}\text { Baseline } \\
\text { low-demand }\end{array}$} & \multicolumn{3}{|c|}{$\begin{array}{c}\text { Baseline } \\
\text { high-demand }\end{array}$} & \multicolumn{3}{|c|}{$\begin{array}{c}\text { BLUE } \\
\text { low-demand }\end{array}$} & \multicolumn{3}{|c|}{$\begin{array}{c}\text { BLUE } \\
\text { high-demand }\end{array}$} \\
\hline & & 2015 & 2030 & 2050 & 2015 & 2030 & 2050 & 2015 & 2030 & 2050 & 2015 & 2030 & 2050 \\
\hline $\begin{array}{l}\text { Recovered } \\
\text { Paper }\end{array}$ & 1 & 3 & 9 & 23 & 4 & 16 & 43 & 4 & 11 & 29 & 5 & 19 & 55 \\
\hline $\begin{array}{l}\text { Chemical } \\
\text { Wood Pulp }\end{array}$ & 2 & 3 & 6 & 10 & 5 & 10 & 17 & 3 & 5 & 8 & 4 & 10 & 16 \\
\hline $\begin{array}{l}\text { Other fibre } \\
\text { Pulp }\end{array}$ & 2 & 2 & 2 & 2 & 2 & 2 & 2 & 2 & 2 & 2 & 2 & 2 & 2 \\
\hline All Pulp & 4 & 6 & 9 & 13 & 7 & 14 & 21 & 6 & 8 & 11 & 7 & 12 & 19 \\
\hline $\begin{array}{l}\text { Household } \\
\text { and Sanitary } \\
\text { Paper }\end{array}$ & 0 & 0 & 3 & 6 & 1 & 5 & 11 & 0 & 3 & 6 & 1 & 5 & 11 \\
\hline $\begin{array}{l}\text { Printing and } \\
\text { Writing Paper }\end{array}$ & 3 & 6 & 12 & 25 & 8 & 21 & 44 & 6 & 12 & 25 & 8 & 21 & 44 \\
\hline $\begin{array}{l}\text { Wrapping, } \\
\text { Packaging } \\
\text { Paper and } \\
\text { Board }\end{array}$ & 3 & 8 & 17 & 38 & 9 & 29 & 68 & 8 & 17 & 38 & 9 & 29 & 68 \\
\hline $\begin{array}{l}\text { All Paper and } \\
\text { Paperboard }\end{array}$ & 8 & 17 & 38 & 81 & 22 & 67 & 148 & 17 & 38 & 81 & 22 & 67 & 148 \\
\hline
\end{tabular}

Sources: FAOSTAT; IPMA, 2010a; IEA estimates.

Trends in energy consumption and the energy mix of India's pulp and paper sector have been analysed according to both the Baseline and BLUE Scenario (Figure 27). In the Baseline Scenario, energy consumption increases from 3 Mtoe in 2007 to 19 Mtoe (low-demand case) and 33 Mtoe (high-demand case) in 2050. In the BLUE Scenario, energy consumption reaches 17 Mtoe (lowdemand case) and 31 Mtoe (high-demand case) in 2050.

Energy consumption in the BLUE Scenario is only $10 \%$ and $6 \%$ lower than in the Baseline Scenario in 2050. The relatively small decrease is partly attributable to higher shares of recovered paper, and biomass and waste used. The combustion efficiency of biomass is generally lower than other energy sources.

While energy consumption increases 6.1 and 10.4 times between 2007 and 2050 in the Baseline Scenario, direct $\mathrm{CO}_{2}$ emissions only increase 4.5 and 7.6 times. Total direct $\mathrm{CO}_{2}$ emissions reaches $36 \mathrm{Mt} \mathrm{CO}_{2}$ (low-demand case) and $62 \mathrm{Mt} \mathrm{CO}_{2}$ (high-demand case) in 2050. 
Figure 27: India's pulp and paper energy consumption by energy source and scenarios

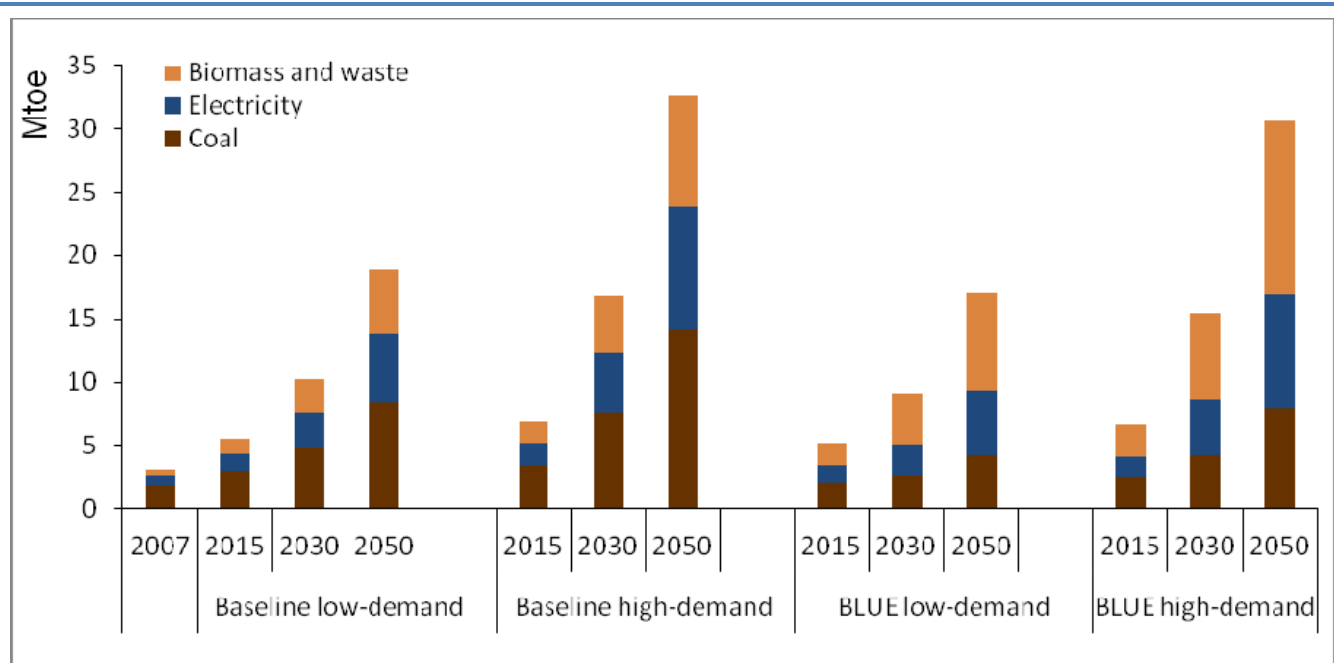

There is a significant shift away from coal in the BLUE Scenario. While coal accounted for $60 \%$ of total energy use is 2007, it only accounts for 44\% in 2050 in the Baseline Scenario and is further reduced to $25 \%$ in the BLUE Scenario. This change in the fuel mix has a major impact on the $\mathrm{CO}_{2}$ intensity of the pulp and paper industry.

In the BLUE Scenario, $\mathrm{CO}_{2}$ emissions are still 2.1 and 3.8 times higher in 2050 than they were in 2007, but a reduction from the Baseline Scenario reaches 52\% in the low-demand case and $49 \%$ in the high-demand cases. Fuel switching is the main factor reducing emissions, accounting for $51 \%$ and $60 \%$ of the reduction in 2050 (Figure 28). CCS is a later option for the sector and will account for 7\% (low-demand case) and 11\% (high-demand case) of the total reduction in 2050.

Figure 28: India's direct $\mathrm{CO}_{2}$ emissions reduction by technology option for pulp and paper

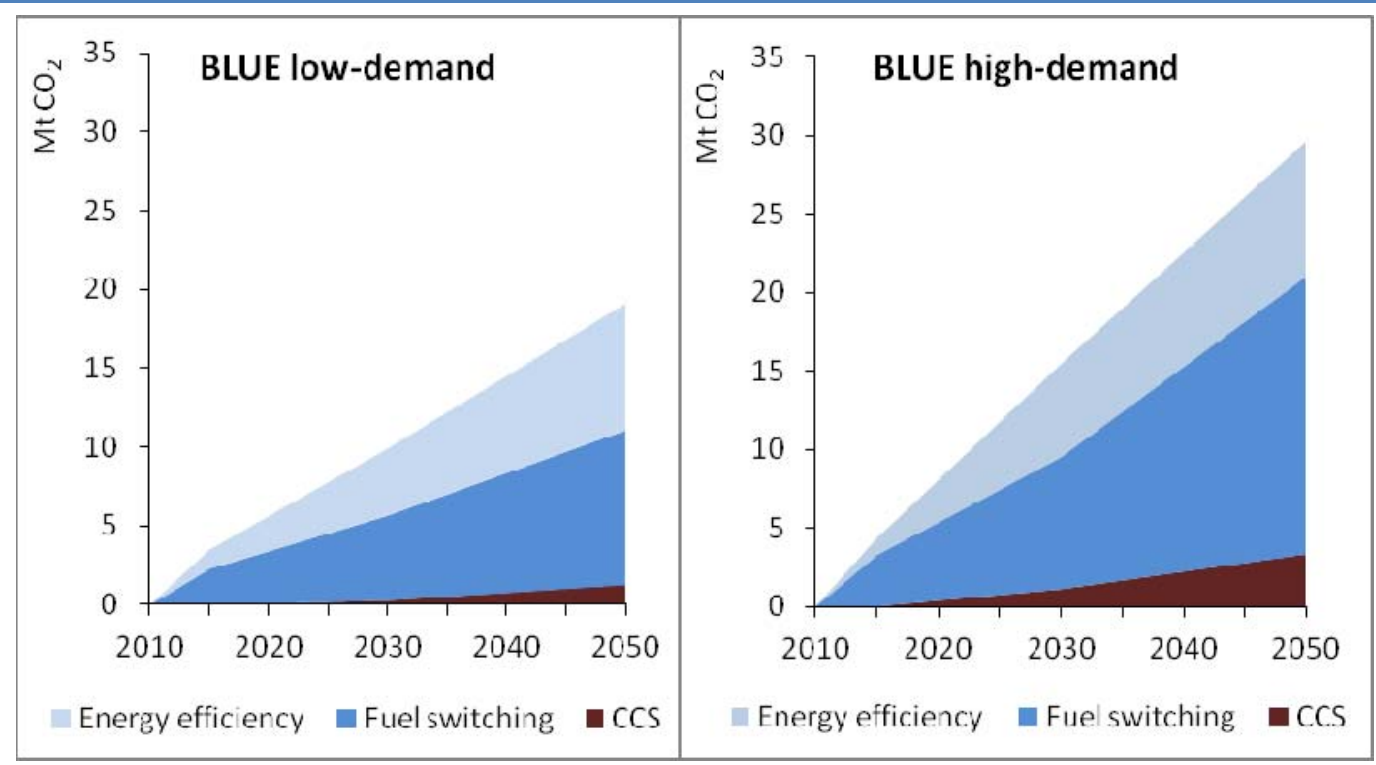

Globally, paper production is estimated to reach almost $800 \mathrm{Mt}$ by 2050 in the low-demand case and over $1100 \mathrm{Mt}$ in the high-demand case. In both cases, China becomes the largest paper 
producer in 2050, accounting for one-third of global production. In the high-demand case, India surpasses the United States to become the second-largest producer.

Recycling levels are already relatively high with a global recycling rate of $50 \%$. Many countries are already at or near their practical limits. But in others, especially developing countries, some growth can be expected in the future. In the Baseline Scenario, the use of recovered paper is expected to reach $54 \%$ in 2050, while in the BLUE Scenario these levels are assumed to increase further to $60 \%$.

Globally, total direct $\mathrm{CO}_{2}$ emissions in the BLUE Scenario are 67\% (low-demand case) and $75 \%$ (high-demand case) lower than in the Baseline Scenario in 2050. Energy efficiency represents the largest contribution to reducing direct emissions, at $54 \%$, followed by fuel switching which accounts for $35 \%$ (Figure 29). In the BLUE Scenario high-demand case, fuel switching plays the most important role in reducing emissions, accounting for $47 \%$ of the reduction, while energy efficiency contributes $36 \%$ of the reduction. By 2050 , total direct $\mathrm{CO}_{2}$ emissions reduction below the Baseline levels is $264 \mathrm{MtCO}_{2}$ in the low-demand case and $418 \mathrm{Mt} \mathrm{CO}_{2}$ in the high-demand case. CCS, which is a later option for the sector, begins to have an impact by 2030 and accounts for $11 \%$ (low-demand case) and 17\% (high demand case) of the reductions.

Figure 29: Global direct $\mathrm{CO}_{2}$ emissions reduction by technology option for pulp and paper

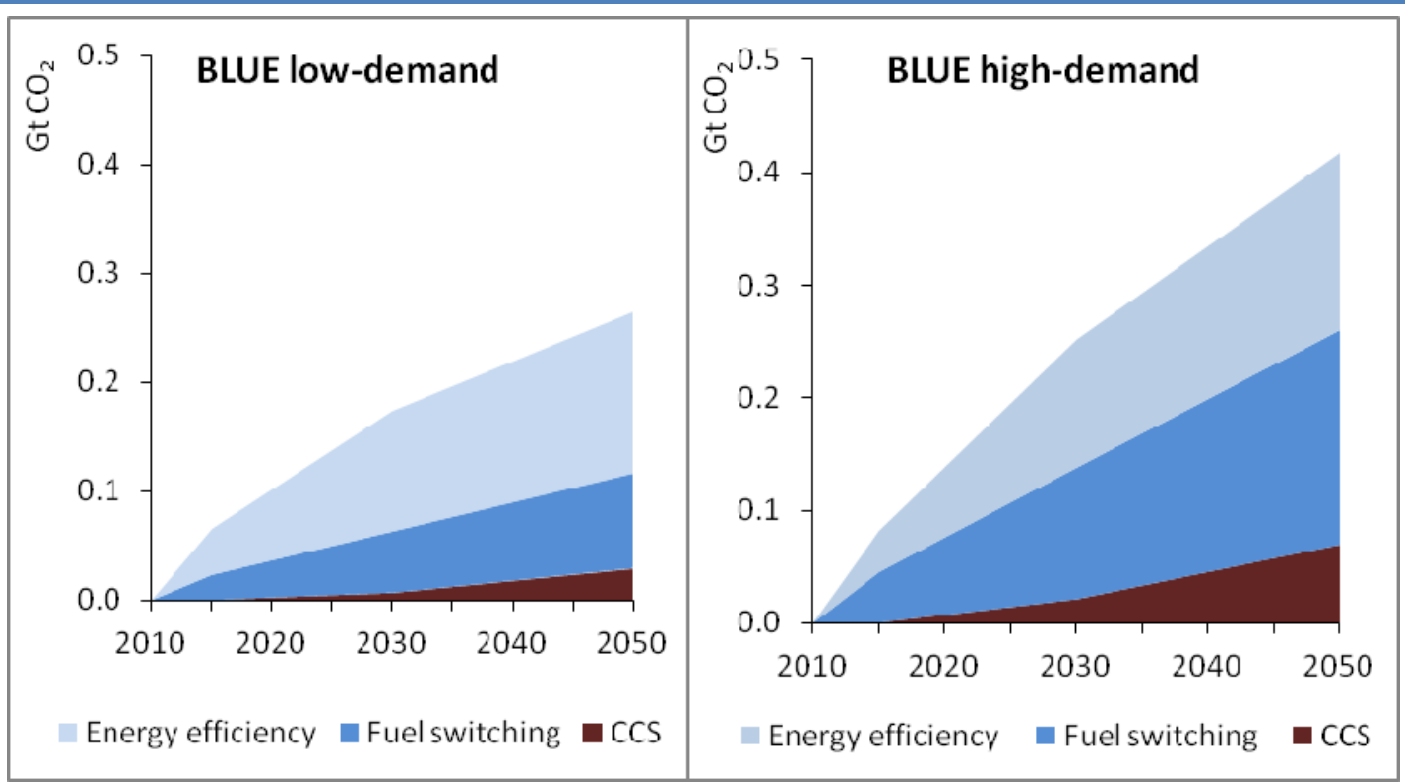

Paper and paperboard consumption is assumed to continue to grow most strongly in non-OECD countries, especially in Asia where demand from China is expected to increase fivefold from current levels by 2050 in the low-demand cases. As a consequence, the global share of paper and paperboard consumption shifts significantly from OECD to non-OECD countries with the share from the former falling from the current rate of $65 \%$ to between $32 \%$ and $24 \%$ by 2050 .

Almost $50 \%$ of the growth in paper and paperboard production between 2007 and 2050 will come from China. As a result, about $25 \%$ of the reduction will also come from this country (Figure 30 ). In the case of North America, production is expected to remain at the same level throughout the projected period. However, given the significant potential for improving energy efficiency and applying CCS resulting in the sector becoming a $\mathrm{CO}_{2}$ sinks (e.g. capturing more $\mathrm{CO}_{2}$ emissions than it actually emits), the region is expected to contribute almost $20 \%$ of the global emissions reduction. 
Figure 30: Regional contribution to reduction in global direct $\mathrm{CO}_{2}$ emissions in pulp and paper, low-demand case

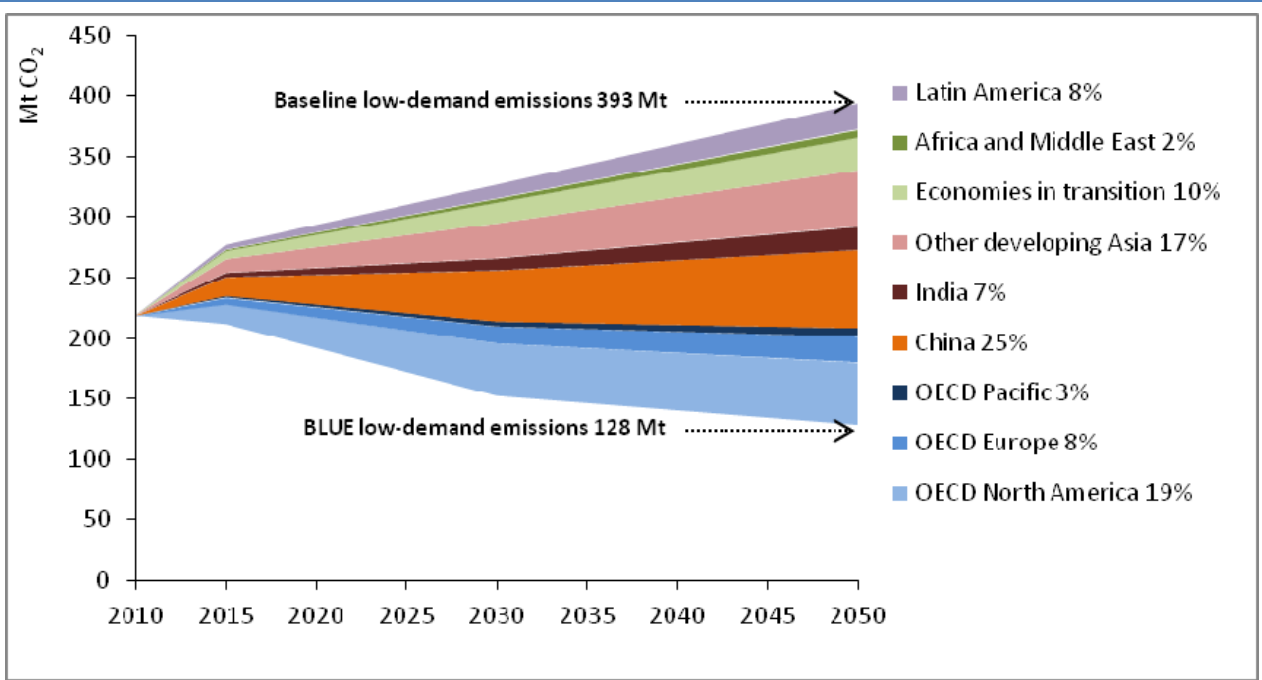

\section{Technology options in the pulp and paper sector}

Implementing BATs and newly emerging technologies would enable the sector to reduce significantly both its energy needs and its $\mathrm{CO}_{2}$ intensity. A wide range of technology options and opportunities need to be deployed if the outcomes implicit in the BLUE Scenario are to be achieved (Table 16).

Table 16: Technology options for the pulp and paper industry

\begin{tabular}{|c|c|c|c|}
\hline Technology & R\&D needs & $\begin{array}{l}\text { Demonstration } \\
\text { needs }\end{array}$ & Deployment milestones \\
\hline Black liquor gasification & $\begin{array}{l}\text { Improved reliability and gas clean- } \\
\text { up }\end{array}$ & Under way & Beginning in 2015 to 2025 \\
\hline $\begin{array}{l}\text { Biomass conversion to } \\
\text { fuels and chemicals }\end{array}$ & $\begin{array}{l}\text { Efficient and lo-cost removal of tar } \\
\text { Production of high-value } \\
\text { chemicals and liquid fuels }\end{array}$ & Under way & Beginning in 2015 to 2025 \\
\hline $\begin{array}{l}\text { Advanced water-removal } \\
\text { technologies }\end{array}$ & $\begin{array}{l}\text { Enhance water-removal } \\
\text { techniques }\end{array}$ & & \\
\hline $\operatorname{ccs}$ & & $\begin{array}{l}\text { Two plants by } \\
2020-2025\end{array}$ & $\begin{array}{l}\text { Starting in } 2030 \\
55 \% \text { of all new plants } \\
\text { equipped with CCS by } 2050\end{array}$ \\
\hline
\end{tabular}

All countries need to try to reach BATs levels by 2025 and to improve on BATs by $15 \%$ to $20 \%$ by 2035, which can be achieved by using black liquor and biomass gasification more widely, increasing waste heat recovery, and implementing new technologies in pulping and paper making.

Research, development and deployment (RD\&D) priorities should focus on: improving biomass conversion technologies; providing more efficient water-extraction technologies; and reducing the use of water in pulp washing and paper making.

Improved reliability and gas clean-up for gasification is needed in the short term. Early commercial biomass-integrated gasification with combined cycle (BIGCC) plants need to be deployed within the next five to ten years and wider deployment should occur from 2015 to 2025. In addition to black liquor gasification, lignin production from black liquor and biomass gasification with synfuel production also offers attractive opportunities to increase biomass use in the sector and to raise the profitability of pulp and paper mills. 


\section{Aluminium}

\section{Overview and context}

India is an important player in the aluminium sector, especially because of its abundant bauxite reserves of 3.3 gigatonnes (Gt) (Metalworld, 2008). India is the fourth-largest producer of bauxite, accounting for $10 \%$ of global production in 2007 . Bauxite is processed to alumina near the bauxite mine or shipped to alumina plants in other parts of the world. India is the seventhlargest producer of alumina.

Alumina production in India increased from 2.3 Mt in 2000 to $2.9 \mathrm{Mt}$ in 2007 (USGS, 2009b). Virtually all alumina is produced in the Bayer process, a combination of an extraction (digestion with caustic soda) and calcination process. Fuel consumption of a Bayer plant can vary between $10 \mathrm{GJ} / \mathrm{t}$ alumina and $15 \mathrm{GJ} / \mathrm{t}$ alumina produced. It is estimated that Indian alumina production currently uses $14.4 \mathrm{GJ} / \mathrm{t}$ alumina.

With a $3.2 \%$ share of global production of primary aluminium, India is among the top ten producers (USGS, 2009c). The $90 \%$ increase in primary production since 2000 was mostly driven by demand for aluminium products arising from the aluminium used in transportation, building and electrical segments.

About $80 \%$ of India's primary aluminium production is based on modern pre-baked technology. As a result, India compares favourably to the most efficient primary aluminium producer in the world. However, most of the energy consumed is in the form of electricity. As most electricity is internally generated and mainly produced from inefficient coal-fired power plants (CSE, 2010), India's production of primary aluminium is one of the most $\mathrm{CO}_{2}$ intensive.

Globally, around $38 \mathrm{Mt}$ of aluminium was produced from bauxite in 2007, more than twice the amount that was produced 20 years earlier. The top three primary aluminium-producing countries - China, Russia and Canada - account for over $50 \%$ of the world's production (Table 17). Production in China, India and particularly in the Middle East is growing rapidly, while it has been declining in the United States and Europe in recent years.

Table 17. Global primary aluminium production, 2007

\begin{tabular}{lccc}
\hline & Production (Mt) & $\begin{array}{c}\text { Production } \\
\text { share (\%) }\end{array}$ & $\begin{array}{c}\text { Cumulative production } \\
\text { share (\%) }\end{array}$ \\
\hline China & 12.6 & 33.2 & 33 \\
\hline Russia & 4.0 & 10.4 & 44 \\
Canada & 3.1 & 8.1 & 52 \\
\hline United States & 2.6 & 6.7 & 59 \\
\hline Australia & 2.0 & 5.2 & 64 \\
\hline Brazil & 1.6 & 4.2 & 68 \\
Norway & 1.3 & 3.4 & 71 \\
\hline India & 1.2 & 3.2 & 75 \\
\hline South Africa & 0.9 & 2.4 & 77 \\
\hline Other & 8.7 & 23.0 & 100 \\
\hline Total & 37.9 & 100.0 & - \\
\hline
\end{tabular}

Source: USGS, 2009c. 
Aluminium production can be split into primary production and recycling. Primary aluminium is produced in three distinct steps: bauxite (ore) mining, a low energy intensity physical process; alumina refining, a medium energy intensity physicochemical process; and aluminium smelting, a highly energy-intensive electrochemical process. Producing aluminium from scrap requires only about $6 \%$ to $7 \%$ of the energy required for primary production because of its relatively low melting temperature $\left(700^{\circ} \mathrm{C}\right.$ to $\left.800^{\circ} \mathrm{C}\right)$ and the fact that it is not bonded to oxygen.

The global production of aluminium from scrap has increased more rapidly than primary production, almost quadrupling from $5 \mathrm{Mt}$ in 1980 to $18 \mathrm{Mt}$ in 2007 (IAI, 2009b). Recycled production has increased to around $25 \%$ of the total amount of aluminium produced, although the share has levelled out in recent years as total demand has increased.

\section{Technology and energy consumption in the aluminium sector}

In alumina refineries, most of the energy used is in the form of steam that is used to heat caustic soda in the digestion process. The calcinations of the alumina also require large amounts of hightemperature heat. More than $90 \%$ of the total energy used in alumina production comes from fossil fuels, with most of the remainder being electricity. Given the high demand for steam, many plants could introduce CHP systems and thereby significantly increase the overall energy efficiency.

The International Aluminium Institute (IAI) conducts an annual survey of facilities world wide ${ }^{18}$ to collect information about energy use in production. The average energy intensity of alumina refineries reported in IAI statistics was $11.7 \mathrm{GJ} / \mathrm{t}$ alumina in 2007, ranging from $10.7 \mathrm{GJ} / \mathrm{t}$ in Latin America to $14.6 \mathrm{GJ} / \mathrm{t}$ in Europe (IAI, 2009a). The IAI statistics also show that the average specific energy consumption of alumina refining has declined by $8 \%$ between 1990 and 2007 (Figure 31). The world average 2007 energy intensity, including Chinese and other non-reporting facilities, is estimated to be $16.6 \mathrm{GJ} / \mathrm{t}$ alumina produced.

Figure 31: Specific energy consumption of metallurgical alumina production

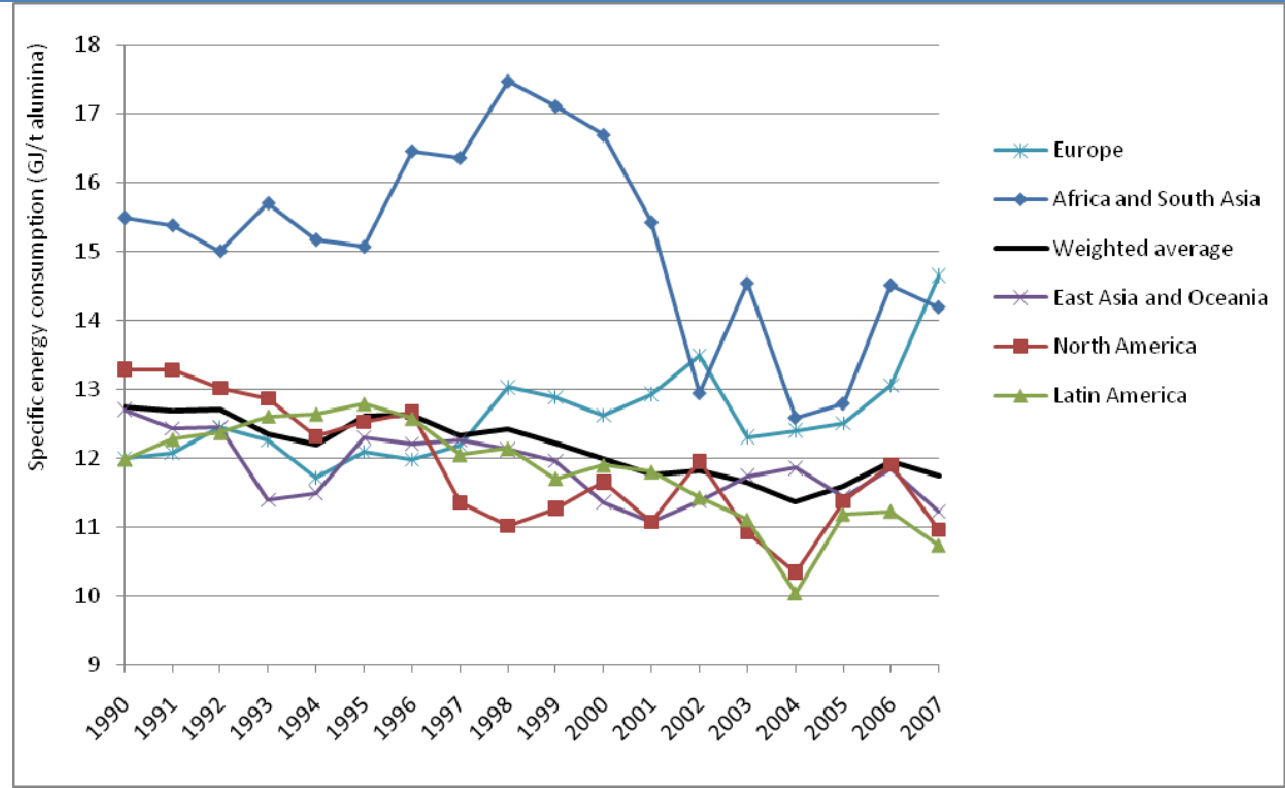

Note: Excludes data for China.

Source: IAI, 2009a.

\footnotetext{
${ }^{18}$ The survey covers around $70 \%$ of global metallurgical alumina and primary aluminium production.
} 
Smelting is the most energy-intensive step in the production of aluminium and is based on the Hall-Héroult process. Alumina is dissolved in an electrolytic bath of molten cryolite within a large carbon- or graphite-lined steel container known as a "pot". A low-voltage, very high-amperage electric current is passed through the electrolyte between a carbon anode, which is made of petroleum coke and pitch, and a cathode, which is formed by the lining of the pot. The strongly bonded aluminium and oxygen atoms in the alumina are split as the high current pulls oxygen ions towards the anode where they react with the carbon, leaving molten aluminium that is deposited at the bottom of the pot and siphoned off from time to time.

More than $80 \%$ of global primary aluminium production now comes from smelters using modern pre-baked anodes, although some facilities still use an older Søderberg technology with in situ baked anodes (Figure 32). Pre-baked smelters use between 13.6 Megawatt-hour per tonne of aluminium (MWh/t) and $15.7 \mathrm{MWh} / \mathrm{t}$ aluminium whereas Søderberg smelters use between 15.1 MWh/t aluminium and 17.5 MWh/t aluminium (EC, 2008).

Figure 32: Smelter technology mix, 1990 to 2008

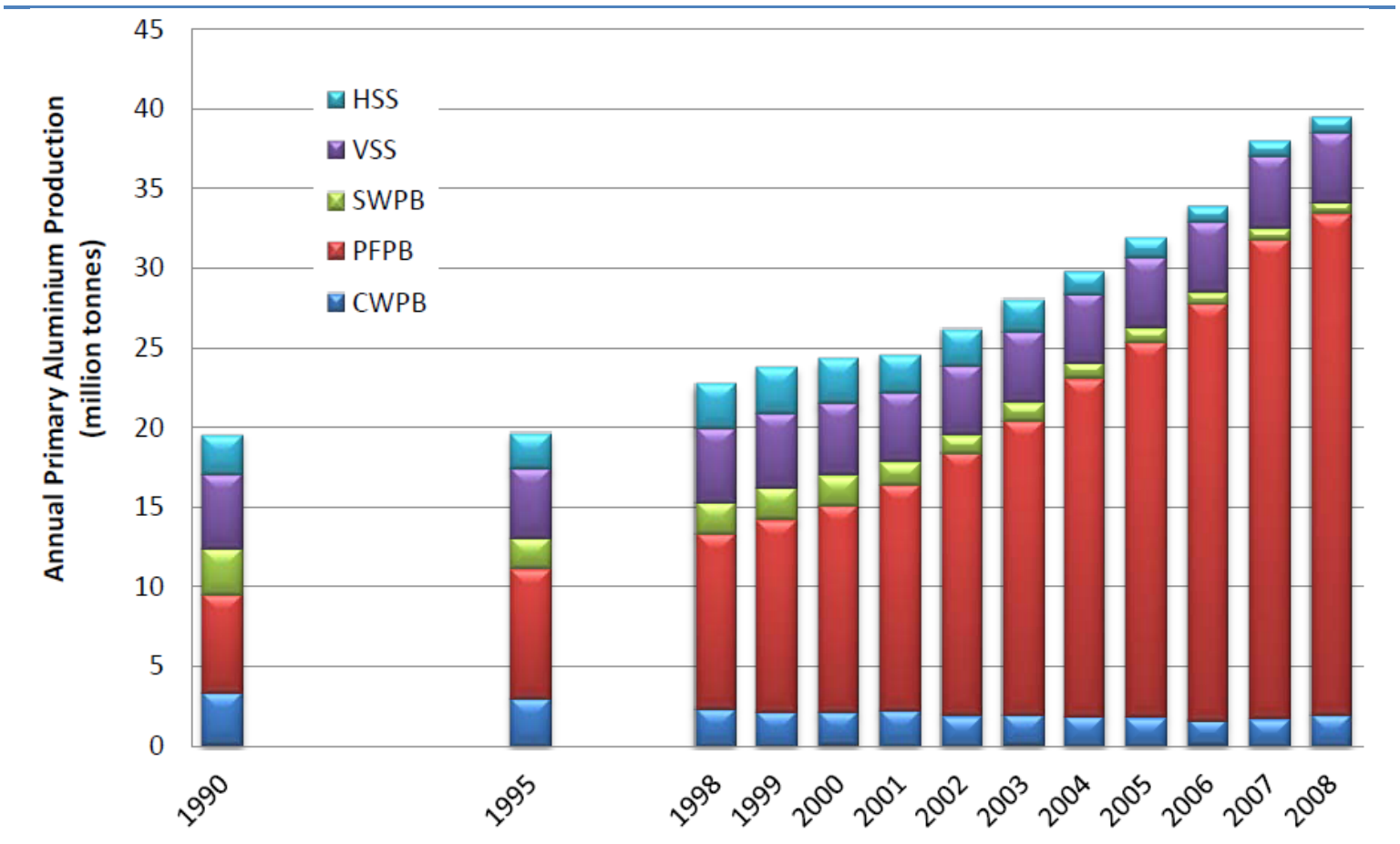

Notes: CWPB - centre work pre-bake; HSS - horizontal stud Søderberg; PFPB - point fed pre-bake; SWPB - side work pre-bake; and VSS - vertical stud Søderberg.

Source: IAI, 2009c.

Specific power consumption for primary aluminium production has declined in most regions. This has been achieved by building new refineries that are more energy efficient and by retrofitting old refineries with new cells. Global average electricity consumption in the industry has declined by about $0.4 \%$ per year since 1980 . It is now around $15.4 \mathrm{MWh} / \mathrm{t}$ aluminium. This differs only slightly among regions. Africa has the most energy-efficient smelters in the IAI dataset, reflecting their relatively young age. However, anecdotal evidence suggests that China, which is not included in the IAI energy statistics, has a more energy-efficient production on average (Tao and Liang, 2008). 


\section{Best available technology and technical savings potentials}

There are a number of ways to improve the energy efficiency of alumina production in the Bayer process. Improved process controls and modified equipment can increase yields. Heat losses can be reduced by: using more CHP; improving heat transfer efficiency; updating calciner technologies and operations; and adopting more effective waste-heat recovery. Such measures could reduce the total use of fuel and electricity to between $9.5 \mathrm{GJ} / \mathrm{t}$ alumina and $10 \mathrm{GJ} / \mathrm{t}$ alumina (ISR, 2000; Worrell et al., 2008), which is a 40\% saving on the global 2007 average consumption of $16.6 \mathrm{GJ} / \mathrm{t}$ alumina.

Like many other countries, India could save a significant amount of energy in the aluminium sector by applying BATs. Given that the primary production process is relatively energy efficient, about two-thirds of these savings, 338 thousands of tonnes of oil equivalent (ktoe), could come from improving the efficiency of the refineries. Overall, the savings would amount to $507 \mathrm{ktoe}$ or about $18 \%$ of the total energy consumed by the sector in 2007.

Globally, the performance of smelters has improved significantly in recent years, but there remains considerable scope for further energy savings. The main opportunities involve: replacing old smelter technologies with modern pre-baked cells; developing process controls that optimise cell-operating conditions; improving insulation to reduce heat losses; and saving electricity in auxiliary technology such as compressors and fans. New world-class plants can achieve around 13.5 megawatt-hour per tonne of aluminium (MWh/t aluminium) (Keniry, 2001), a saving of $13 \%$ compared to the current world average.

Smaller energy savings are also possible in other processes, such as in anode manufacture and in recycling. The BAT fuel consumption for anode production is $2.45 \mathrm{GJ} / \mathrm{t}$ anode (Worrell et al., 2008), around $70 \%$ less than the current global average. The BAT for recycling using natural gasfired regenerative furnaces consumes between $2.0 \mathrm{GJ} / \mathrm{t}$ aluminium and $2.5 \mathrm{GJ} / \mathrm{t}$ aluminium (Worrell et al., 2008; Bayliss and Marks, 2008), which is around $50 \%$ less than conventional cold air technologies. BATs provide the possibility to reduce energy use in aluminium production by up to $10 \%$ compared with current levels (Figure 33 ).

Figure 33: Energy savings potential in 2007 for aluminium, based on BAT

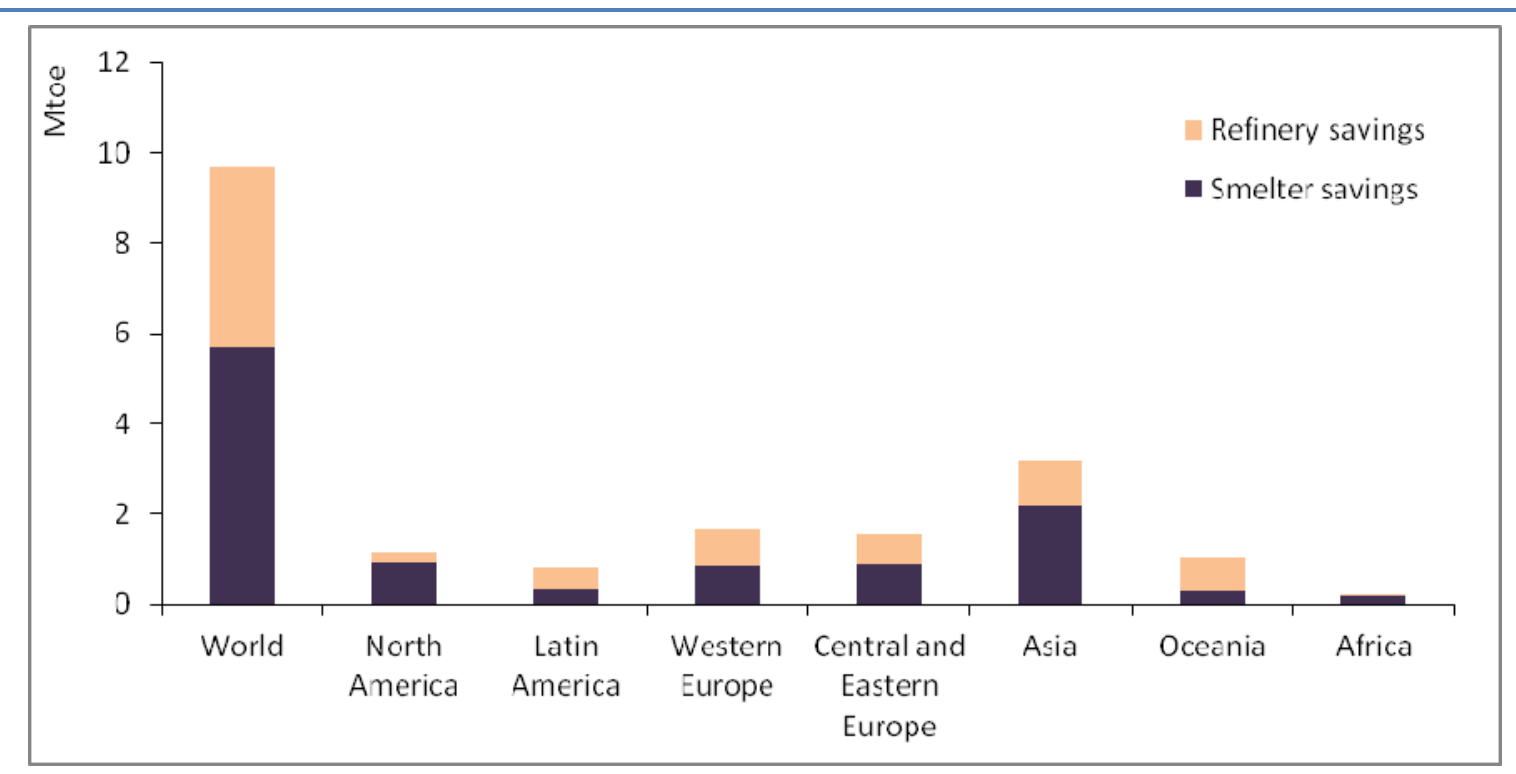




\section{Scenario results}

The per capita consumption of finished aluminium product in India was $0.9 \mathrm{~kg} / \mathrm{cap}$ in 2007. This is very low compared to the global average of $6.7 \mathrm{~kg} / \mathrm{cap}$. The overall demand for aluminium is projected to grow substantially up to 2050 and is driven by higher consumption in a wide range of sectors. As a result, the per capita demand is expected to reach $6.3 \mathrm{~kg} / \mathrm{cap}$ in the low-demand case and $8.8 \mathrm{~kg} / \mathrm{cap}$ in the high-demand case.

To meet this increased demand, India's primary production of aluminium in 2050 increases to $11 \mathrm{Mt}$ and $17 \mathrm{Mt}$ in the Baseline low- and high-demand cases (Table 18). India would become the second-largest producer of aluminium.

Table 18: India's aluminium production by scenarios

\begin{tabular}{|l|l|l|l|l|l|l|l|l|l|l|l|l|l|l|}
\hline & & \multicolumn{3}{|c|}{$\begin{array}{c}\text { Baseline } \\
\text { low-demand }\end{array}$} & \multicolumn{3}{c|}{$\begin{array}{c}\text { Baseline } \\
\text { high-demand }\end{array}$} & \multicolumn{3}{c|}{$\begin{array}{c}\text { BLUE } \\
\text { low-demand }\end{array}$} & \multicolumn{3}{c|}{$\begin{array}{c}\text { BLUE } \\
\text { high-demand }\end{array}$} \\
\hline & $\mathbf{2 0 0 7}$ & $\mathbf{2 0 1 5}$ & $\mathbf{2 0 3 0}$ & $\mathbf{2 0 5 0}$ & $\mathbf{2 0 1 5}$ & $\mathbf{2 0 3 0}$ & $\mathbf{2 0 5 0}$ & $\mathbf{2 0 1 5}$ & $\mathbf{2 0 3 0}$ & $\mathbf{2 0 5 0}$ & $\mathbf{2 0 1 5}$ & $\mathbf{2 0 3 0}$ & $\mathbf{2 0 5 0}$ \\
\hline Alumina & 2.9 & 3.8 & 5.8 & 7.3 & 4.0 & 7.4 & 9.7 & 3.7 & 5.5 & 6.6 & 3.9 & 7.0 & 8.7 \\
\hline $\begin{array}{l}\text { Primary } \\
\text { Aluminium }\end{array}$ & 1.2 & 2.0 & 6.5 & 11.0 & 2.0 & 10.9 & 17.5 & 1.9 & 6.2 & 9.9 & 2.0 & 10.3 & 15.7 \\
\hline $\begin{array}{l}\text { Recycled } \\
\text { Aluminium }\end{array}$ & 1.0 & 2.5 & 8.6 & 14.6 & 2.8 & 15.1 & 25.0 & 2.5 & 8.8 & 15.1 & 2.9 & 15.4 & 26.0 \\
\hline
\end{tabular}

The picture that emerges from the BLUE Scenario is slightly different from that of the Baseline Scenario. The production of recycled aluminium would be about $4 \%$ higher in the BLUE Scenario. Given that the production of recycled aluminium required $6 \%$ to $7 \%$ of the energy for primary aluminium, and taking into account the decreasing demand for alumina production, this small shift has larger benefits than may appear on the energy consumption of the sector.

Improvements in energy intensity from 2007 to 2050, which will be driven by the introduction of efficient technologies and increased production of recycled aluminium, will be not enough to offset the increasing demand for energy from the strong growth in production. In the Baseline Scenario, energy consumption is 5.6 and 8.8 times higher in 2050 than in 2007, reaching 16 Mtoe (low-demand case) and 25 Mtoe (high-demand case).

In the BLUE Scenario, energy use in 2050 is $16 \%$ (low-demand case) and 22\% (high-demand case) lower than in the equivalent Baseline Scenario. In the BLUE Scenario low-demand case, the energy efficiency gains are largely achieved through the further development of existing technology. In the BLUE Scenario high-demand case, introducing wetted drained cathodes and inert anodes more widely from 2020 and reducing carbothermic technologies from 2030 could reduce the average electricity intensity of smelting in 2050 to $10.9 \mathrm{MWh} / \mathrm{t}$ primary aluminium.

India's total direct and indirect $\mathrm{CO}_{2}$ emissions in the various industries were analysed under the different scenarios (Figure 34). Aluminium is an electricity-intensive sector. Furthermore, the decrease in alumina production over the period, resulting from increased recycling, reduces the need for fossil fuels. By 2050 , electricity accounts for over $70 \%$ of the total energy consumption under both scenarios. This emphasises the importance of adopting strategies to reduce the $\mathrm{CO}_{2}$ intensity of power generation.

While decarbonising power generation is an important component in reducing the carbon footprint of the aluminium sector, other steps need to be taken to reduce the carbon footprint further under the BLUE Scenario. 
Figure 34: India's direct and indirect $\mathrm{CO}_{2}$ emissions in aluminium

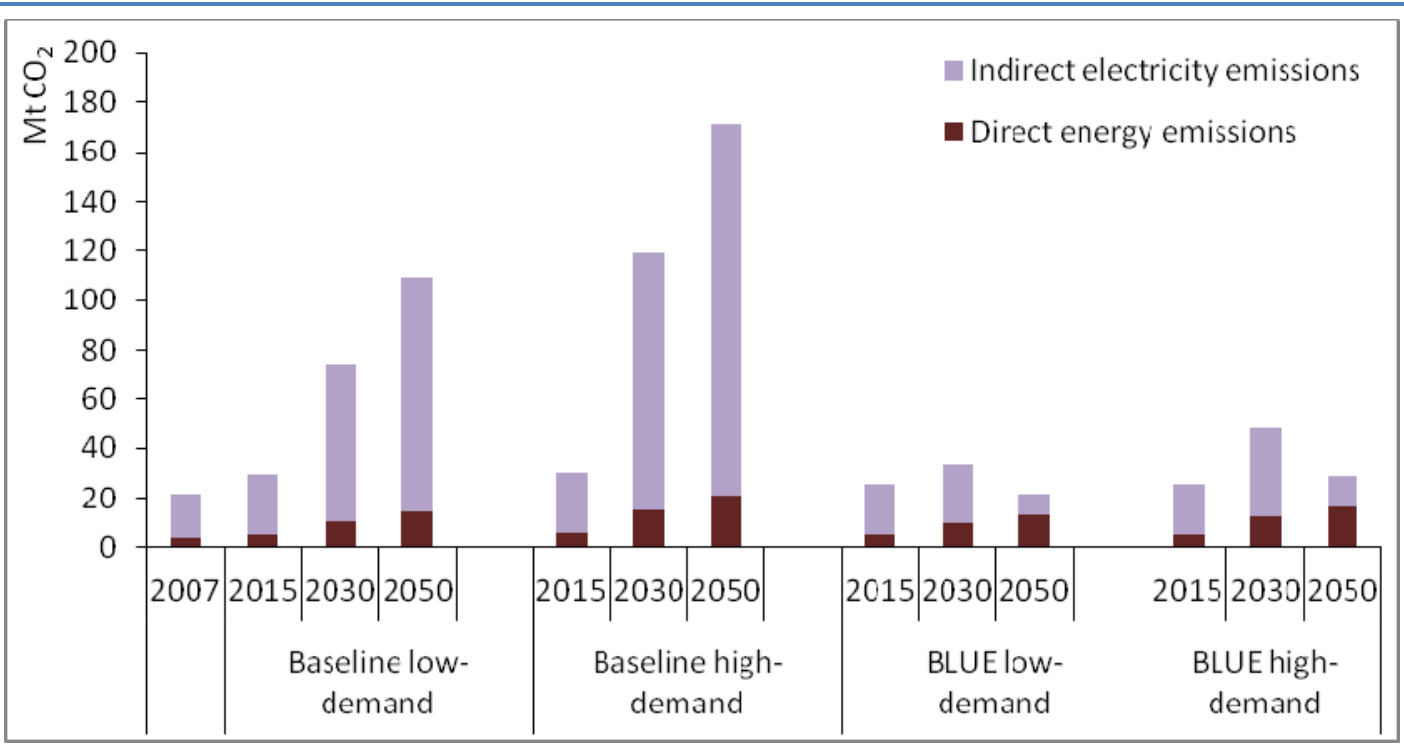

While direct $\mathrm{CO}_{2}$ emissions are three to four times higher in 2050 than in 2007 in the BLUE Scenario, they are $16 \%$ (low-demand case) to $24 \%$ (high-demand case) lower than in the Baseline Scenario. In both the cases, energy efficiency is the largest contributor to the reduction accounting for $48 \%$ and $56 \%$ (Figure 35 ). Recycling will also be an important contributor with $38 \%$ and $27 \%$ of the reductions below the Baseline Scenario in 2050.

Figure 35: India's direct $\mathrm{CO}_{2}$ emissions reduction by technology option for aluminium

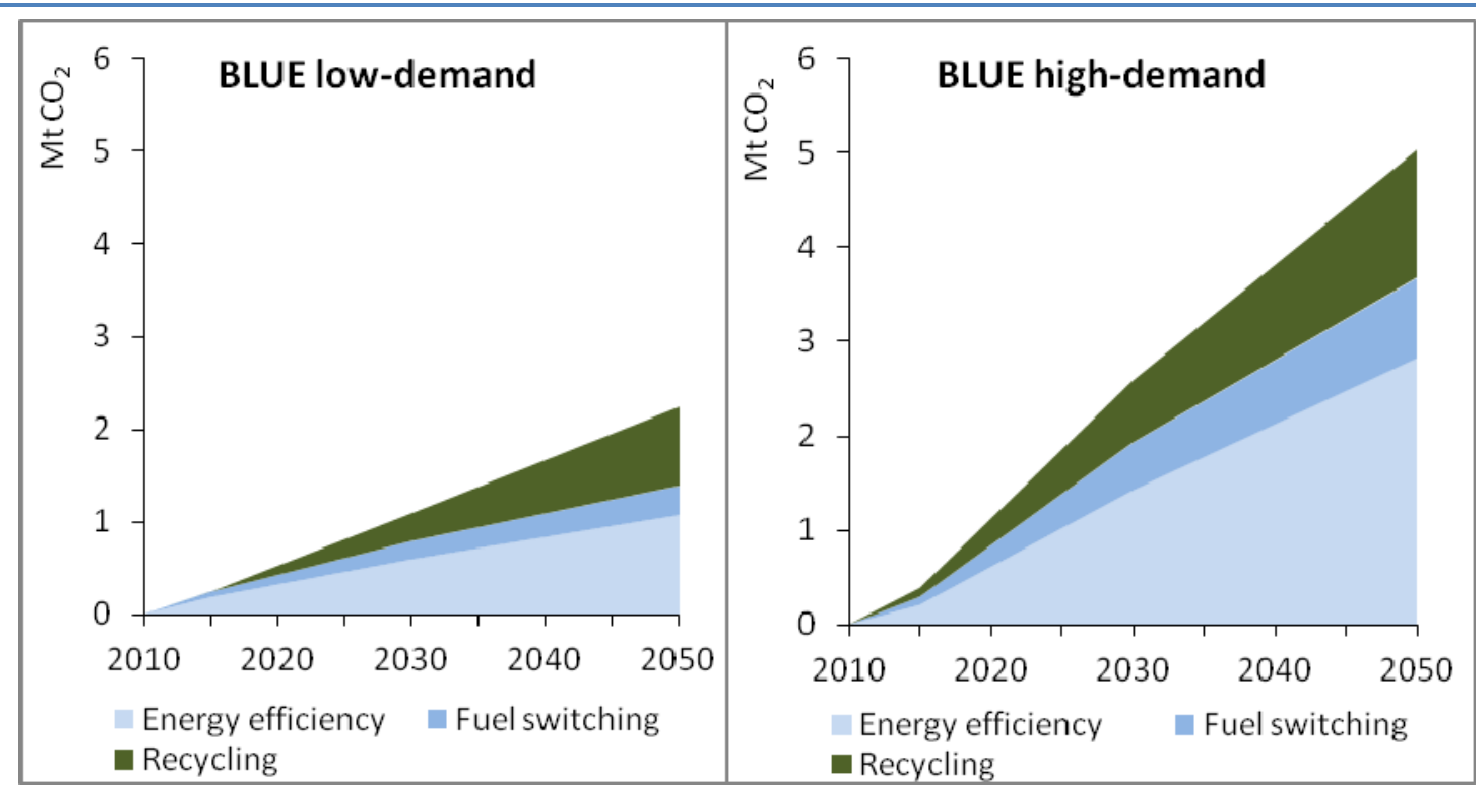

Globally, demand for aluminium is assumed to grow substantially up to 2050 because of higher consumption in a wide range of sectors, especially transport, construction and engineering. To meet this increased demand, primary aluminium production reaches $95 \mathrm{Mt}$ by 2050 in the Baseline Scenario low-demand case and $127 \mathrm{Mt}$ in the high-demand case. In both cases, most growth is outside the OECD, with strong increases in Asia, the economies in transition, and Africa 
and the Middle East. Aluminium recycling is also expected to increase significantly. In the Baseline Scenario, recycled production rises to $47 \mathrm{Mt}$ (low-demand case) and $63 \mathrm{Mt}$ in 2050 (highdemand case) and continues to represent around one-third of finished products. In the two cases of the BLUE Scenario, total aluminium production is assumed to be the same as in the corresponding Baseline Scenario cases, but recycled production increases to $56 \mathrm{Mt}$ (low-demand case) and $76 \mathrm{Mt}$ (high-demand case) in 2050, representing about $40 \%$ of finished products. ${ }^{19}$

In the BLUE Scenario, total direct and indirect $\mathrm{CO}_{2}$ emissions ${ }^{20}$ fall by $63 \%$ (low-demand case) and 72\% (high-demand case) in 2050 compared to the equivalent Baseline Scenario cases, which is around $21 \%$ lower than current levels. Most of the reduction in $\mathrm{CO}_{2}$ emissions comes from using low-carbon electricity.

However, decarbonising the power sector will not be sufficient to achieve the emissions reduction required in the BLUE Scenario. Additional $\mathrm{CO}_{2}$ savings that are needed will have to come from direct $\mathrm{CO}_{2}$ emissions reduction. Reduction in direct emissions are, therefore, significantly greater in the BLUE Scenario high-demand case than in the BLUE Scenario lowdemand case (Figure 36). In the low-demand case, about $65 \%$ of the direct emissions reduction comes from an increased use of scrap. In the high-demand case, recycling makes a much smaller contribution, with the largest share of reduction coming from improved energy efficiency.

Figure 36: Global direct $\mathrm{CO}_{2}$ emissions reduction by technology option for aluminium

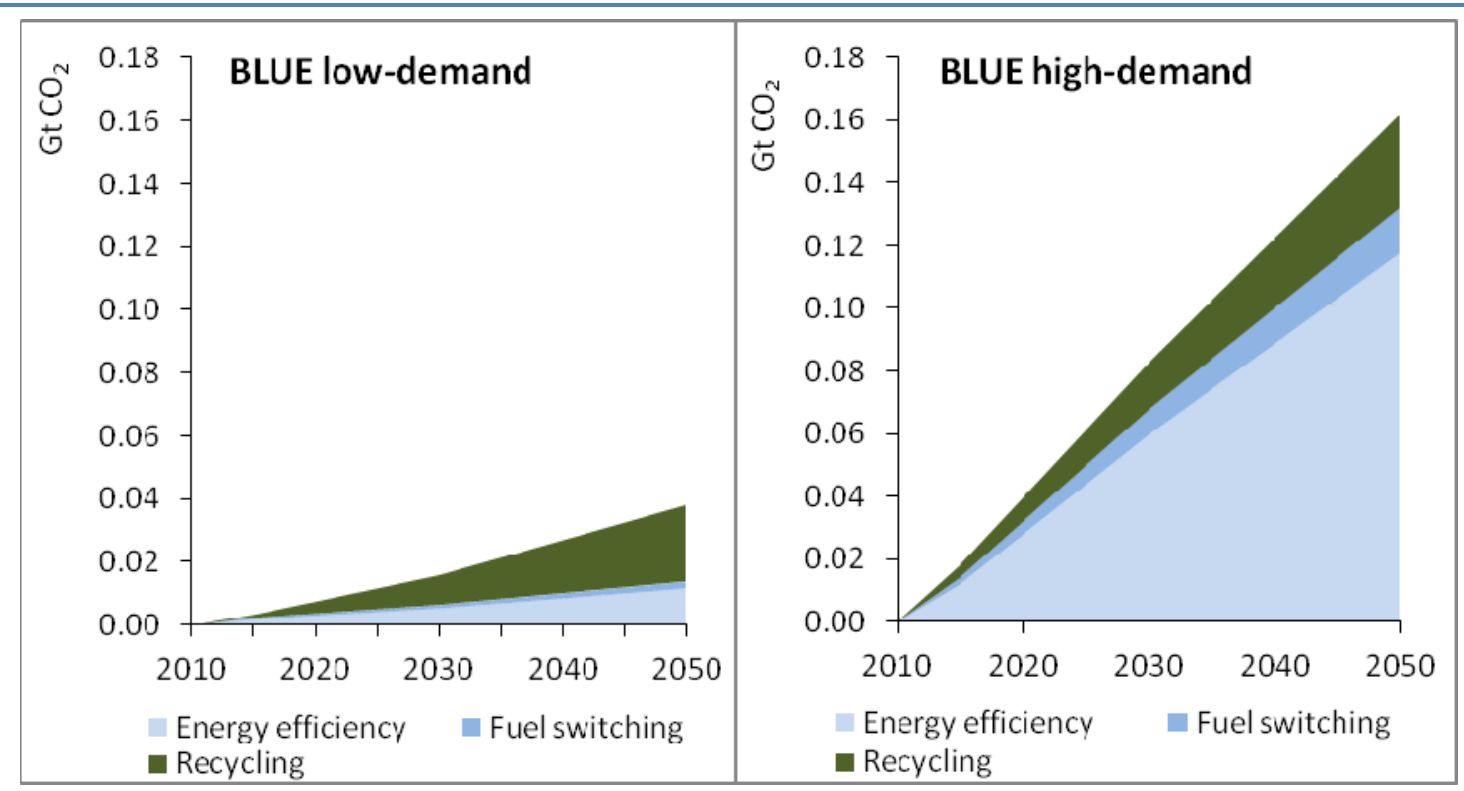

Direct $\mathrm{CO}_{2}$ emissions in the aluminium sector will continue to grow throughout 2007 to 2050, but will be $17 \%$ (low-demand case) and 39\% (high-demand case) lower in the BLUE Scenario than under the Baseline Scenario (Figure 37).

Many Chinese bauxite deposits have high silica content and so are of a low grade. These require a more complex refining process. Only $14 \%$ of China's alumina output is currently produced by the standard Bayer process; the remainder uses a combination of sintering and part of the Bayer process (Li et al., 2008). The energy intensity of such combined processes ranges from

\footnotetext{
${ }^{19}$ Production of aluminium is higher than demand as some of the aluminium is returned for recycling by customers before being made into finished products and a small percentage is lost during the recycling process.

${ }^{20}$ As indirect $\mathrm{CO}_{2}$ emissions account for $75 \%$ of total emissions in the aluminium industry it is important to look at total direct and indirect emissions for this sector.
} 
$24 \mathrm{GJ} /$ tonne to $52 \mathrm{GJ} /$ tonne of alumina (Liu et al., 2006; Li et al., 2008) making them between two and four times more energy intensive than the ordinary Bayer process. This explains the country's potential to reduce direct and indirect $\mathrm{CO}_{2}$ emissions significantly. China contributes about $50 \%$ of the reduction from the Baseline Scenario, even when taking into account both direct and indirect emissions reduction.

Figure 37: Regional contribution to reducing global direct $\mathrm{CO}_{2}$ emissions in aluminium, lowdemand cases

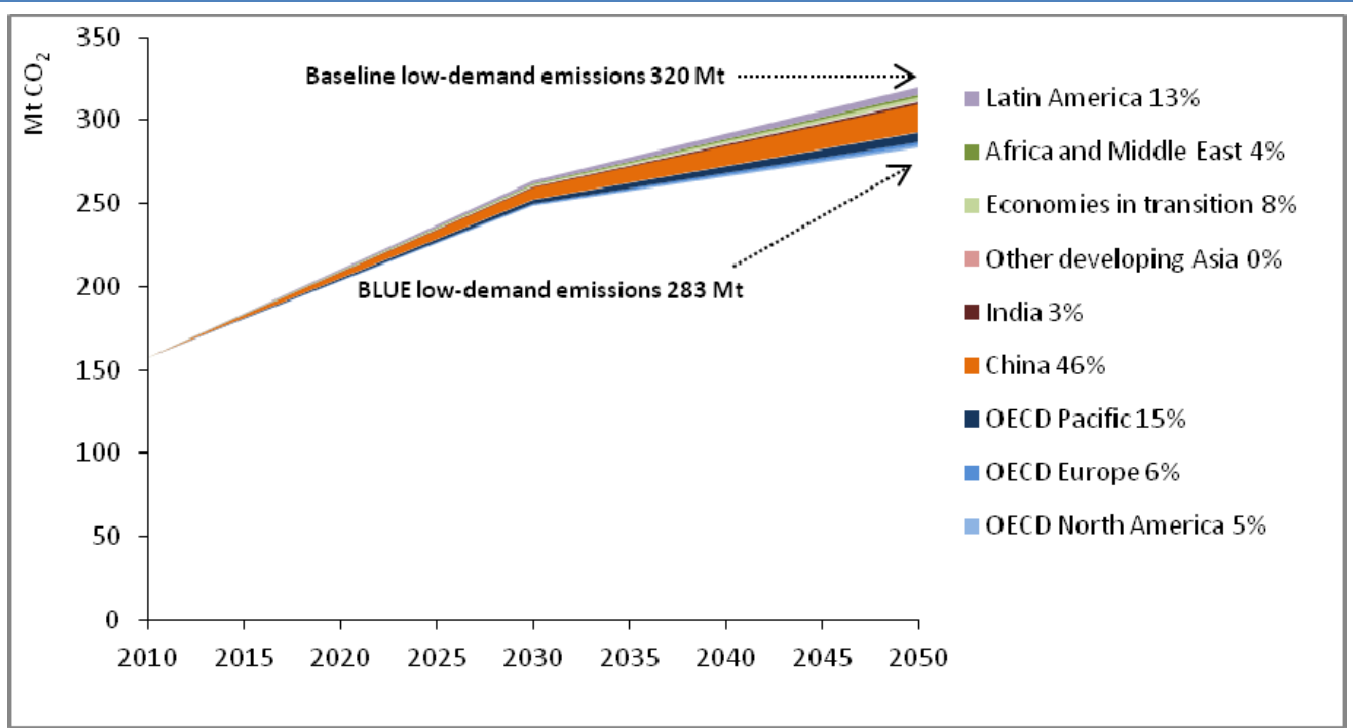

\section{Technology options in the aluminium sector}

Reducing $\mathrm{CO}_{2}$ emissions in the generation of the electricity used in smelters is the single largest opportunity for long-term emissions reduction in the aluminium sector. This is particularly true for India, where a large share of electricity is generated in inefficient coal-fired captive power plants. Particular attention should focus on improving the efficiency of captive power plants and sourcing more electricity from renewable energy.

Globally, around $40 \%$ to $50 \%$ of the total electricity used by the aluminium industry comes form zero-carbon hydroelectric sources, often in remote locations where there are few competing uses for the electricity. Measures to create a global carbon price would encourage new aluminium plants to be sited where they have access to cheap, low-carbon electricity. In the longer term, the average $\mathrm{CO}_{2}$ intensity of grid electricity is likely to decrease substantially in many countries so that by 2050 low-carbon grid electricity may become the norm.

Increasing the share of recycling in total production can help reduce energy use and $\mathrm{CO}_{2}$ emissions. But given the long lifetime of aluminium in some markets and products, over threequarters of the aluminium ever produced is still in use.

Future technological developments could also provide an opportunity to reduce the direct emissions of $\mathrm{CO}_{2}$ from aluminium smelting (Table 19). But although the two most promising technological developments - inert anodes and carbothermic reduction - have both been the subject of research for many years, neither has yet reached commercial scale. An alternative would be to combine conventional cell technologies with CCS, but this option is also still only at the research stage. 
Table 19: Technology options for the aluminium industry

\begin{tabular}{|c|c|c|c|}
\hline Technology & R\&D needs & Demonstration needs & Deployment milestones \\
\hline $\begin{array}{l}\text { Wetted drained } \\
\text { cathodes }\end{array}$ & & Ready for demonstration & $\begin{array}{l}\text { Deployment to start by } \\
2015 \text { with full } \\
\text { commercialisation by } 2020\end{array}$ \\
\hline Inert anodes & $\begin{array}{l}\text { Extensive testing at } \\
\text { laboratory and batch scale }\end{array}$ & $\begin{array}{l}\text { Ready to be demonstrated } \\
\text { at plant level }\end{array}$ & $\begin{array}{l}\text { Deployment to start in } \\
2015-2020 \text { with full } \\
\text { commercialisation by } 2030\end{array}$ \\
\hline Carbothermic reduction & $\begin{array}{l}\text { Extensive research under } \\
\text { way }\end{array}$ & $2020-2025$ & $\begin{array}{l}\text { Deployment to start } \\
\text { between } 2030 \text { and } 2040 \\
\text { with full commercialisation } \\
\text { by } 2050\end{array}$ \\
\hline Kaolinite reduction & Research under way & $2025-2030$ & $\begin{array}{l}\text { Deployment to start } \\
\text { between } 2035 \text { and } 2045\end{array}$ \\
\hline
\end{tabular}

Page | 67 



\section{Chapter 3. Alternative case for India: Strong growth}

The Energy Technology Perspectives 2010 and this paper analyses and compares two different variants of the Baseline and BLUE scenarios: the low- and high-demand cases. This approach does not aim to forecast what will happen, but rather to demonstrate the many opportunities to create a more secure and more sustainable energy future under different scenarios. The scenarios analysed are based the latest gross domestic product (GDP) growth projections from the World Energy Outlook 2009 for years 2007 to 2030, which are then extrapolated to 2050 (Table 20).

Table 20: GDP projections (\% per year, based on purchasing power parity)

\begin{tabular}{|lccc}
\hline & $\mathbf{2 0 0 7 - 2 0 1 5}$ & $\mathbf{2 0 1 5 - 2 0 3 0}$ & $\mathbf{2 0 3 0 - 2 0 5 0}$ \\
\hline OECD & 1.4 & 1.9 & 1.2 \\
\hline OECD North America & 1.8 & 2.3 & 1.4 \\
\hline United States & 1.8 & 2.2 & 1.3 \\
\hline OECD Europe & 1.0 & 1.8 & 0.7 \\
\hline OECD Pacific & 1.3 & 1.3 & 1.7 \\
\hline Non-OECD & 5.7 & 4.1 & 3.4 \\
\hline Economies in transition and non-OECD Europe & 3.3 & 3.3 & 3.5 \\
\hline Middle East & 4.5 & 4.0 & 2.5 \\
\hline Africa & 4.7 & 3.1 & 3.1 \\
\hline Latin America & 3.1 & 2.5 & 2.5 \\
\hline China & 8.8 & 4.4 & 3.8 \\
\hline India & 7.0 & 5.9 & 3.3 \\
\hline Other developing Asia & 3.2 & 3.5 & 2.6 \\
\hline World & 3.3 & 3.0 & 2.6 \\
\hline
\end{tabular}

Sources: Hawksworth, 2006 and IEA, 2010.

However, many factors may influence the way an economy develops in the future. The growth observed for any economy can be higher or lower than might be expected.

India is one of the countries that is expected to achieve the strongest growth in all sectors of the economy in the future. But one question remains: what if India's growth goes beyond that modelled in the International Energy Agency (IEA) BLUE Scenario. In this context, the IEA developed an alternative case for India's industrial sector - the strong growth case. This section presents the results of the analysis for this new alternative variant of the Baseline and BLUE scenarios.

It should be noted that the underlying assumptions on prices (both for energy and $\mathrm{CO}_{2}$ ) were not changed in this case. As a result, the technological developments will follow the path of the Baseline and BLUE scenarios and the higher growth in material production will inevitably increase the energy consumption and $\mathrm{CO}_{2}$ emissions.

\section{Basic assumption for India's strong growth case}

India's short-term energy policy is mainly driven by its Five-Year Plans, which are prepared by the Planning Commission. The Five-Year Plans are developed from the bottom up with each ministry projecting its main development needs and proposing how best to achieve them. The Planning Commission is then tasked with ensuring that individual plans are co-ordinated together to meet the government's development and economic policies. Currently the Eleventh Five-Year Plan 
(2007-2012) is being implemented (Gol, 2008). This plan sets a target for $9 \%$ growth in GDP in the five-year period $2007 / 08$ to $2011 / 12$ with acceleration during the period to reach $10 \%$ by the end of the plan. The intent is to maintain a $10 \%$ growth in the following Five-Year Plan (2012/13 to 2016/17) in order to double the per capita income by the end of the Twelfth Five-Year Plan.

Table 21: High-level indicators for India in ETP 2010 and strong growth cases

\begin{tabular}{lcccccc}
\hline & & & ETP 2010 & & Strong growth \\
\hline & 2007 & 2015 & 2030 & 2050 & 2015 & 2030 \\
\hline $\begin{array}{l}\text { GDP (billion USD using } \\
\text { purchasing power parity) }\end{array}$ & 4025 & 6916 & 16340 & 31280 & 8020 & 25189 \\
$\begin{array}{l}\text { GDP (billion USD using } \\
\text { exchange rates) }\end{array}$ & 771 & 1325 & 3131 & 5993 & 1536 & 4826 \\
$\begin{array}{l}\text { GDP per capita (thousands USD } \\
\text { using exchange rates) }\end{array}$ & 3583 & 5343 & 11007 & 19383 & 6197 & 16967 \\
$\begin{array}{l}\text { GDP per capita (thousands USD } \\
\text { using purchasing power parity) }\end{array}$ & 686 & 1024 & 2109 & 3713 & 1187 & 3251 \\
$\begin{array}{l}\text { Growth rate from previous } \\
\text { period }\end{array}$ & - & $7.0 \%$ & $5.9 \%$ & $3.3 \%$ & $9.0 \%$ & $9.0 \%$ \\
\hline
\end{tabular}

Note: GDP is expressed in constant 2000 USD.

Taking these targets into account, the IEA has developed the alternative "strong growth" case where the annual growth rate of GDP is higher than that used to develop ETP 2010 (Table 21). Under the strong growth case, GDP would increase by $9 \%$ per year until 2030 , and then by $6.3 \%$ per year between 2030 and 2050. Indian GDP would be 75\% higher in 2050 than in the ETP 2010 scenario. GDP per capita in 2050 will be about 35\% higher than the world average of USD 25100 and similar to GDP per capita in the European Union.

\section{Materials consumption and production under the strong growth case}

Such a growth in the GDP per capita will have an important impact on the level of materials demanded by the population. This is reflected in the demand projections in Table 22, represented in kilograms per capita (kg/cap). India's demand for most materials in 2050 as represented in the strong growth case will be slightly higher than the world average. The noticeable exceptions are: chemicals and petrochemicals for which demand in India will be slightly lower than the world average; and cement for which demand will be twice as high as the world average.

Table 22: India's materials demand per capita, kg/cap

\begin{tabular}{lccccccc}
\hline & \multicolumn{2}{c}{$\begin{array}{c}\text { ETP 2010 } \\
\text { low-demand }\end{array}$} & \multicolumn{2}{c}{$\begin{array}{c}\text { ETP 2010 } \\
\text { high-demand }\end{array}$} & \multicolumn{2}{c}{ Strong growth } \\
\hline & 2007 & 2030 & 2050 & 2030 & 2050 & 2030 & 2050 \\
\hline Primary aluminium & 1 & 4 & 6 & 4 & 6 & 12 & 21 \\
\hline Cement & 151 & 325 & 400 & 325 & 400 & 620 & 1026 \\
\hline Chemicals and petrochemicals & & & & & & & \\
\hline \multicolumn{1}{c}{ HVC } & 9 & 17 & 28 & 17 & 28 & 36 & 65 \\
\hline \multicolumn{1}{c}{ Ammonia } & 12 & 16 & 19 & 16 & 19 & 22 & 29 \\
\hline \multicolumn{1}{c}{ Methanol } & 0.1 & 0.4 & 0.6 & 0.4 & 0.6 & 0.5 & 1.0 \\
\hline Iron and steel & 49 & 150 & 200 & 150 & 200 & 250 & 350 \\
\hline Paper and paperboard & 8 & 23 & 43 & 23 & 43 & 52 & 121 \\
\hline
\end{tabular}


This growth in materials demand is reflected in the increased production of materials. In the strong growth case, India's production of the five key materials covered is expected to increase ten times the levels of 2007 by 2050 (Figure 38). Analysing the sustainability of resources available to meet such a strong growth is beyond the scope of this working paper.

Figure 38: India's materials production under the ETP 2010 and strong growth cases

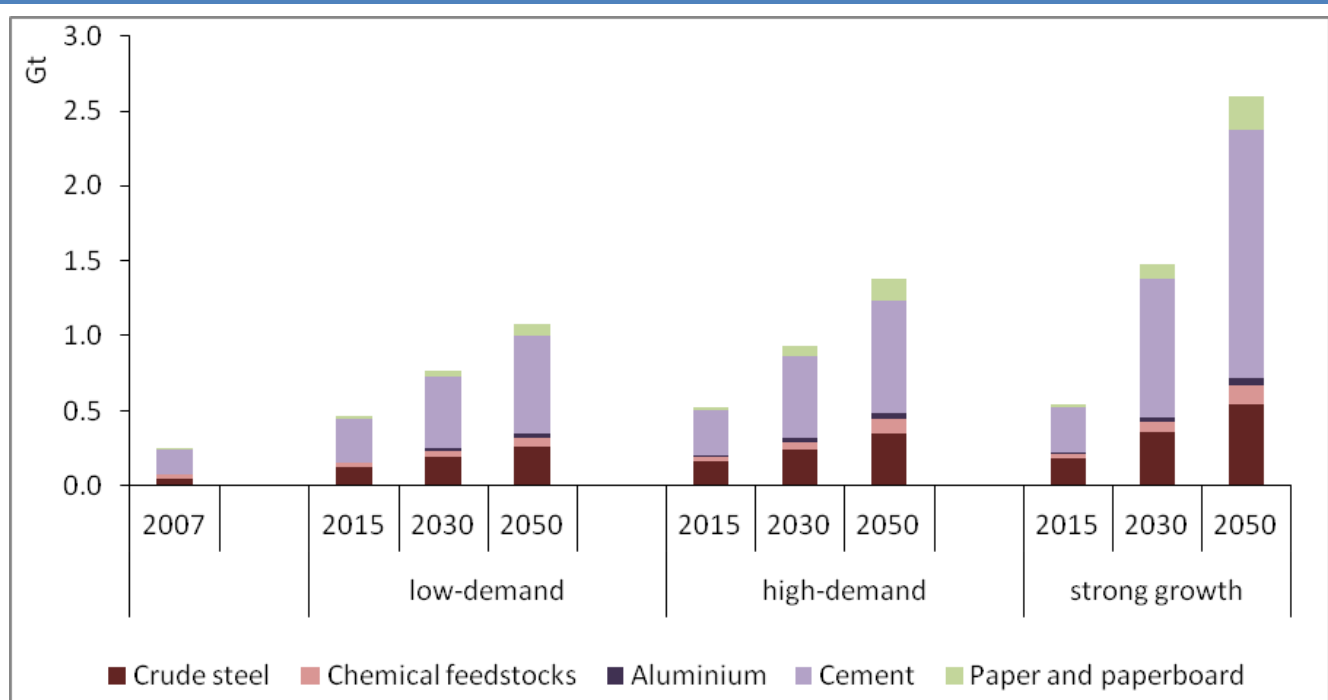

\section{Scenarios for industrial energy use and $\mathrm{CO}_{2}$ emissions in the strong growth case}

In the Baseline Scenario, total final energy use in the strong growth case is estimated to increase more than five times, from 150 Mtoe in 2007 to 822 Mtoe in 2050. Fossil fuels currently constitute about $67 \%$ of the total final energy used in industry and will continue to dominate in the Baseline Scenario (Figure 39). Fossil fuels will account for $74 \%$ of total industrial energy consumption, with coal being the largest source with a share of almost $50 \%$ of industrial consumption.

Figure 39: Final energy use in India's industry

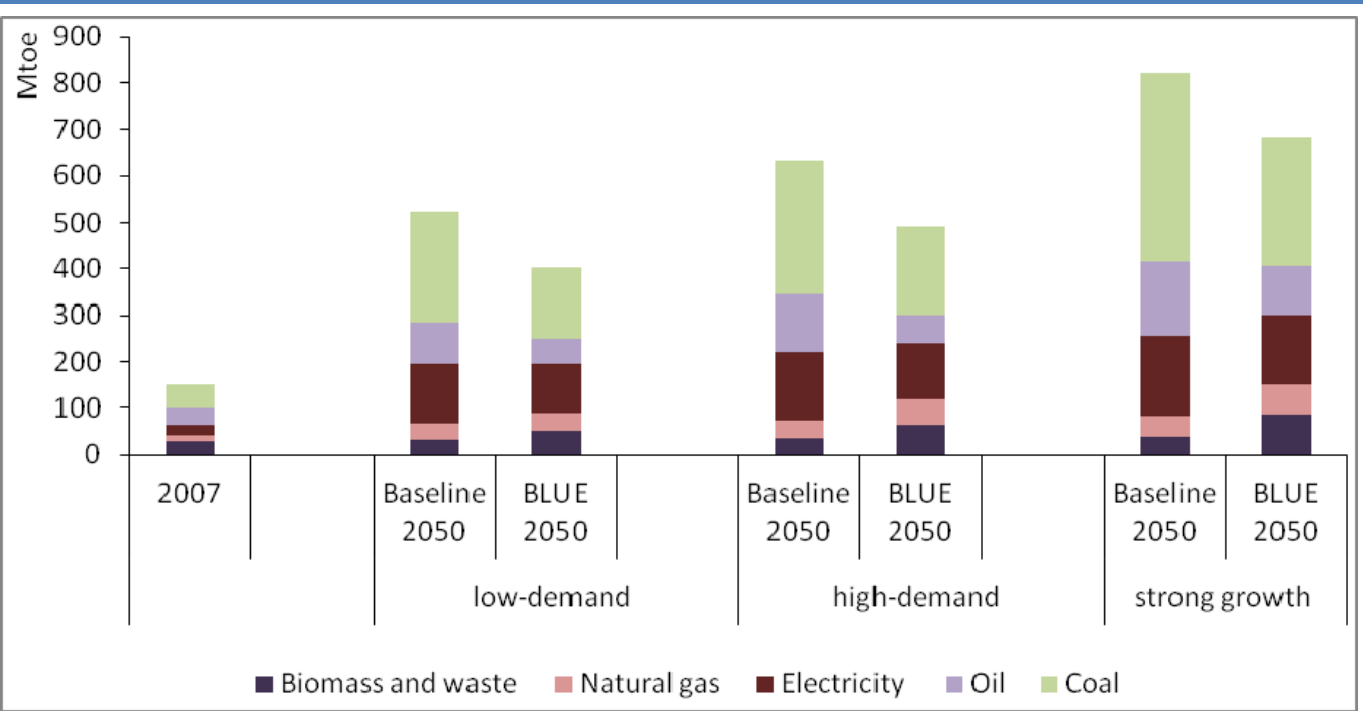


The industrial energy consumption in the BLUE Scenario, although higher than in 2007, is noticeably lower than in the associated Baseline Scenario. In the BLUE Scenario, energy consumption in the strong growth case is $17 \%$ lower in 2050 than in the Baseline Scenario. The reduction in the strong growth case is lower than the potential of the low-demand case $(23 \%)$ and high-demand case $(22 \%)$.

In the Baseline Scenario, industrial direct $\mathrm{CO}_{2}$ emissions will increase at a faster pace than the total energy consumption. The higher rate of increase in emissions is mostly attributable to the higher share of fossil fuels and, more noticeably of coal, in the fuel mix. In the Baseline strong growth scenario, total industrial direct $\mathrm{CO}_{2}$ emissions are projected to increase from 413 million tonnes of $\mathrm{CO}_{2}\left(\mathrm{Mt} \mathrm{CO}_{2}\right.$ ) in 2007 to $2807 \mathrm{MtCO}_{2}$ in 2050 (Figure 40).

Direct $\mathrm{CO}_{2}$ emissions in the BLUE Scenario will increase at a much slower pace than energy consumption. In 2050, direct $\mathrm{CO}_{2}$ emissions in the strong growth case will amount to $1519 \mathrm{Mt}$ $\mathrm{CO}_{2}, 46 \%$ below the Baseline emission in 2050. But despite this important reduction, emissions in the BLUE strong growth scenario will still be $268 \%$ higher in 2050 than the current levels.

Figure 40: India's direct energy and process $\mathrm{CO}_{2}$ emissions by industrial sector

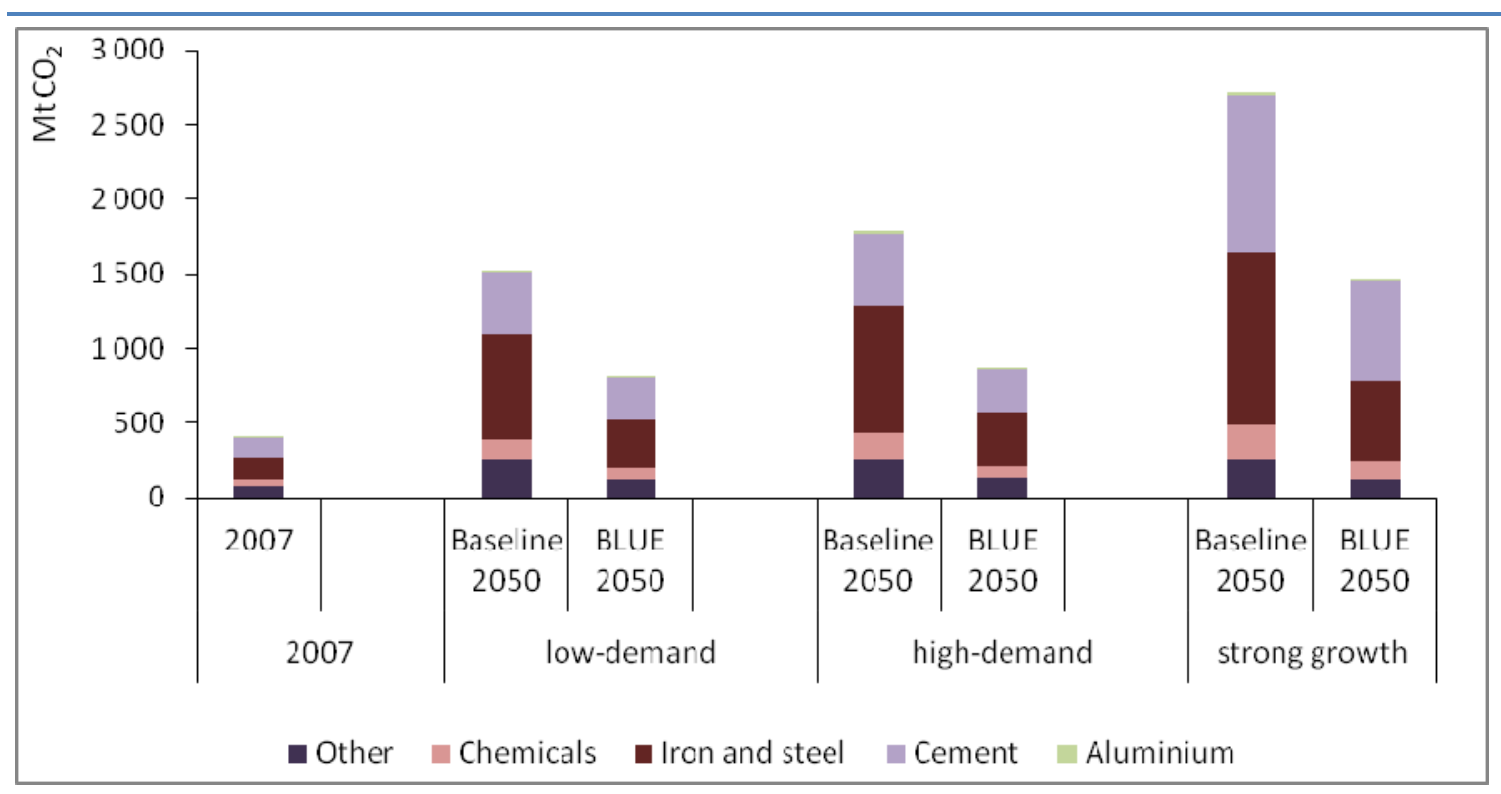

Reduction of direct $\mathrm{CO}_{2}$ emissions in industry can be achieved by deploying existing best available technology (BAT) and by developing and deploying new technologies that can: deliver improved energy efficiency; enable fuel and feedstock switching; and encourage greater levels of recycling and carbon capture and storage (CCS).

While energy efficiency is the most important option for reducing direct $\mathrm{CO}_{2}$ emissions in the low-demand case (accounting for $41 \%$ of the reduction), the picture changes considerably with the higher production assumed in the strong growth case. In the strong growth case, energy efficiency only accounts for $28 \%$ of the emissions reduction (Figure 41 ) while CCS is the most important option accounting for $48 \%$. Two main factors explain the relative important of each option in the strong growth case.

Given the production capacity being built to meet the very high demand in materials, the average age of the capital stock will be younger in the strong growth case than in the ETP 2010 cases. Given that new build is generally more efficient than older plants, the overall energy intensity of the capital stock will be improved. As a result, the intensity will be closer to the BAT values. 
In the BLUE Scenario, the majority of plants are built with CCS. Given the important share of new build in the strong growth case, CCS will play a key role for the industry. However, this increase in CCS will result in an increase in energy demand, which partly explains why energy consumption in the strong growth case is only $17 \%$ below the Baseline Scenario.

Figure 41: Options for reducing direct $\mathrm{CO}_{2}$ emissions from India's industry in the strong growth case

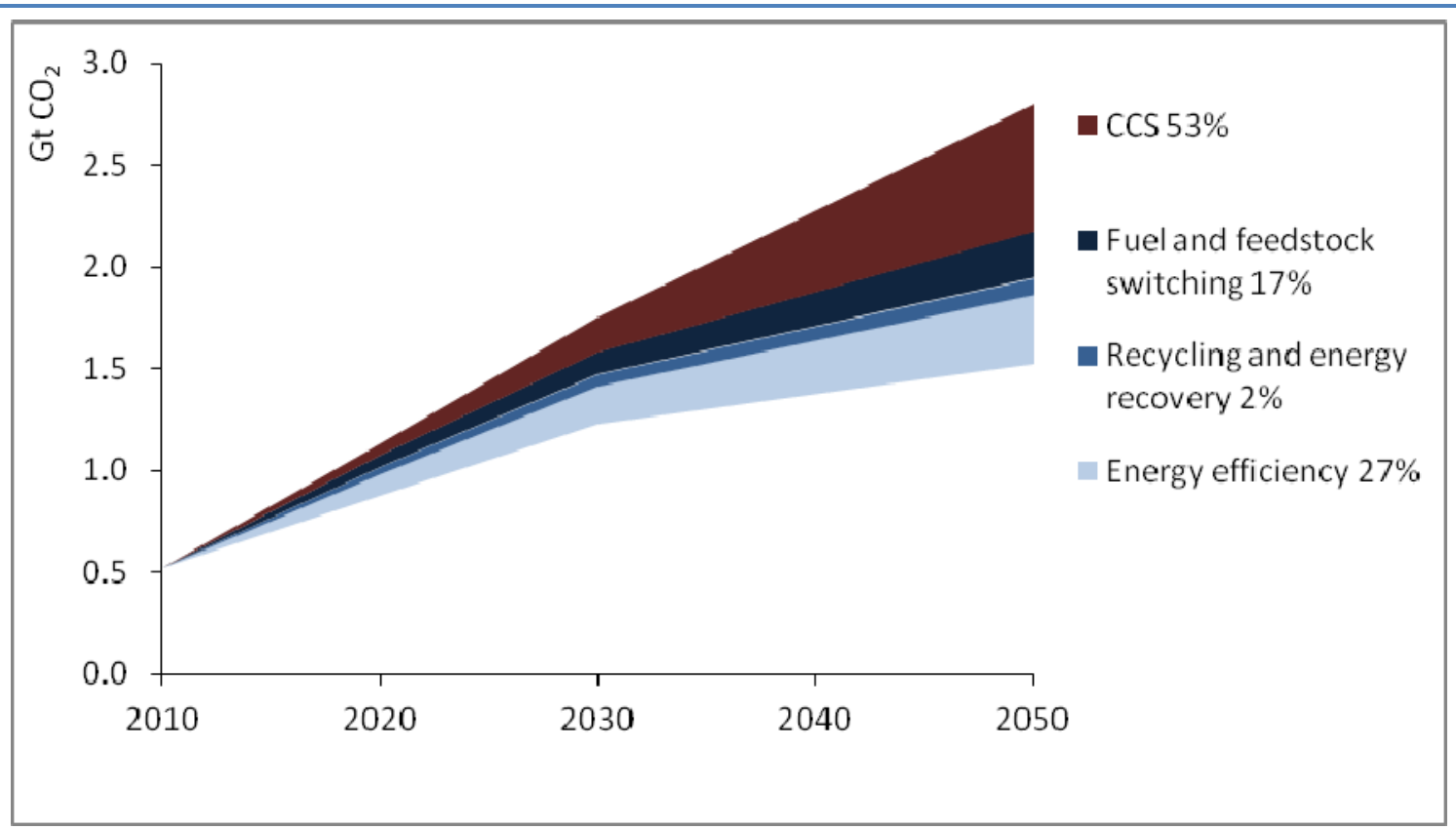

While the Baseline and BLUE scenarios, and their three variants (low-demand, high-demand and strong growth), provide different perspectives on the potential trends in future energy consumption and $\mathrm{CO}_{2}$ emissions, they all convey the same message. India's economic growth over the next 40 years will be one of the strongest world wide. Most of the industrial capacity is still to be built and will remain in place for a long time.

The challenge for India will be to achieve this economic growth while improving their energy security but without locking in high emissions. In identifying the step towards achieving this, national technology roadmaps for the most promising low-carbon technologies should be developed. It will also require international collaboration on a number of initiatives. Enhanced international co-operation for researching, developing, sharing and transferring technologies will be required. International mechanisms for reducing carbon such as the Clean Development Mechanism (CDM) will need to play a role in deploying low-carbon energy technologies in India. 



\section{Annex A. Key trends in India's industrial sector}

Table A.1: Demand projection for industry, $\mathrm{kg} / \mathrm{cap}$

\begin{tabular}{|c|c|c|c|c|c|c|c|c|c|c|}
\hline & \multirow[b]{2}{*}{2007} & \multicolumn{3}{|c|}{ Low-demand } & \multicolumn{3}{|c|}{ High-demand } & \multicolumn{3}{|c|}{ Strong growth } \\
\hline & & 2015 & 2030 & 2050 & 2015 & 2030 & 2050 & 2015 & 2030 & 2050 \\
\hline Crude steel & 49 & 100 & 150 & 200 & 125 & 175 & 250 & 150 & 250 & 350 \\
\hline Cement & 151 & 225 & 325 & 400 & 234 & 364 & 460 & 234 & 620 & 1026 \\
\hline \multicolumn{11}{|l|}{ Chemicals and petrochemicals } \\
\hline HVC & 9 & 11 & 17 & 28 & 14 & 27 & 50 & 14 & 36 & 65 \\
\hline Ammonia & 12 & 13 & 16 & 19 & 15 & 19 & 23 & 16 & 22 & 29 \\
\hline Methanol & 0.1 & 0.2 & 0.4 & 0.6 & 0.2 & 0.4 & 0.7 & 0.2 & 0.5 & 1.0 \\
\hline Paper and paperboard & 8 & 14 & 23 & 43 & 17 & 39 & 76 & 18 & 57 & 120 \\
\hline Aluminium (finished products) & 0.9 & 1.9 & 3.5 & 6.3 & 2.2 & 5.9 & 8.8 & 5.9 & 11.8 & 20.6 \\
\hline
\end{tabular}

Table A.2: Materials production in the Baseline Scenario, Mt

\begin{tabular}{|c|c|c|c|c|c|c|c|c|c|c|}
\hline & \multirow[b]{2}{*}{2007} & \multicolumn{3}{|c|}{$\begin{array}{c}\text { Baseline } \\
\text { low-demand }\end{array}$} & \multicolumn{3}{|c|}{$\begin{array}{c}\text { Baseline } \\
\text { high-demand }\end{array}$} & \multicolumn{3}{|c|}{$\begin{array}{l}\text { Baseline } \\
\text { strong growth }\end{array}$} \\
\hline & & 2015 & 2030 & 2050 & 2015 & 2030 & 2050 & 2015 & 2030 & 2050 \\
\hline \multicolumn{11}{|l|}{ Iron and steel sector } \\
\hline Crude steel & 53 & 131 & 200 & 266 & 169 & 242 & 355 & 189 & 361 & 550 \\
\hline Iron BF & 29 & 96 & 128 & 128 & 129 & 158 & 187 & 143 & 253 & 334 \\
\hline Iron - smelt reduction & 0 & 0 & 0 & 0 & 0 & 0 & 0 & 0 & 0 & 0 \\
\hline DRI - gas based & 5 & 7 & 10 & 11 & 8 & 11 & 12 & 7 & 11 & 11 \\
\hline DRI - coal based & 13 & 33 & 69 & 120 & 38 & 79 & 143 & 34 & 74 & 132 \\
\hline Scrap availability & 10 & 24 & 38 & 51 & 31 & 46 & 70 & 39 & 84 & 142 \\
\hline
\end{tabular}




\begin{tabular}{|c|c|c|c|c|c|c|c|c|c|c|}
\hline & \multirow[b]{2}{*}{2007} & \multicolumn{3}{|c|}{$\begin{array}{l}\text { Baseline } \\
\text { low-demand }\end{array}$} & \multicolumn{3}{|c|}{$\begin{array}{c}\text { Baseline } \\
\text { high-demand }\end{array}$} & \multicolumn{3}{|c|}{$\begin{array}{l}\text { Baseline } \\
\text { strong growth }\end{array}$} \\
\hline & & 2015 & 2030 & 2050 & 2015 & 2030 & 2050 & 2015 & 2030 & 2050 \\
\hline \multicolumn{11}{|l|}{ Cement sector } \\
\hline Cement & 170 & 291 & 482 & 646 & 303 & 540 & 742 & 303 & 920 & 1656 \\
\hline Clinker-to-cement ratio & 0.84 & 0.80 & 0.76 & 0.75 & 0.80 & 0.76 & 0.75 & 0.80 & 0.74 & 0.74 \\
\hline \multicolumn{11}{|c|}{ Chemical and petrochemical sector } \\
\hline Ethylene & 3 & 5 & 10 & 18 & 6 & 16 & 31 & 7 & 21 & 41 \\
\hline Propylene & 2 & 3 & 6 & 10 & 4 & 9 & 19 & 4 & 12 & 24 \\
\hline$B T X$ & 5 & 6 & 10 & 17 & 7 & 15 & 29 & 8 & 20 & 39 \\
\hline Ammonia & 13 & 17 & 24 & 30 & 19 & 26 & 33 & 21 & 32 & 47 \\
\hline Methanol & 0.1 & 0.2 & 0.4 & 0.8 & 0.2 & 0.5 & 1.0 & 0.2 & 0.6 & 1.4 \\
\hline \multicolumn{11}{|l|}{ Pulp and paper sector } \\
\hline Pulp & 4 & 6 & 9 & 13 & 7 & 14 & 21 & 6 & 11 & 19 \\
\hline Chemical wood pulp & 2 & 3 & 6 & 10 & 5 & 10 & 17 & 3 & 8 & 14 \\
\hline Mechanical wood pulp & 0 & 1 & 1 & 1 & 1 & 1 & 2 & 1 & 1 & 3 \\
\hline Other fibre pulp & 2 & 2 & 2 & 2 & 2 & 2 & 2 & 2 & 2 & 2 \\
\hline Paper and paperboard & 8 & 17 & 38 & 81 & 22 & 67 & 148 & 23 & 95 & 232 \\
\hline $\begin{array}{l}\text { Household and } \\
\text { sanitary paper }\end{array}$ & 0 & 0 & 3 & 6 & 1 & 5 & 11 & 1 & 7 & 18 \\
\hline Newsprint & 1 & 2 & 4 & 7 & 3 & 9 & 17 & 3 & 10 & 24 \\
\hline $\begin{array}{l}\text { Printing and } \\
\text { writing paper }\end{array}$ & 3 & 6 & 12 & 25 & 8 & 21 & 44 & 8 & 30 & 70 \\
\hline $\begin{array}{l}\text { Wrapping, Packaging } \\
\text { paper and board }\end{array}$ & 3 & 8 & 17 & 38 & 9 & 29 & 68 & 10 & 43 & 108 \\
\hline $\begin{array}{l}\text { Paper and } \\
\text { paperboard NES }\end{array}$ & 1 & 1 & 2 & 4 & 1 & 4 & 8 & 1 & 5 & 12 \\
\hline Recovered paper & 1 & 3 & 9 & 23 & 4 & 16 & 43 & 4 & 23 & 68 \\
\hline
\end{tabular}




\begin{tabular}{|c|c|c|c|c|c|c|c|c|c|c|}
\hline & \multirow[b]{2}{*}{2007} & \multicolumn{3}{|c|}{$\begin{array}{c}\text { Baseline } \\
\text { low-demand }\end{array}$} & \multicolumn{3}{|c|}{$\begin{array}{c}\text { Baseline } \\
\text { high-demand }\end{array}$} & \multicolumn{3}{|c|}{$\begin{array}{l}\text { Baseline } \\
\text { strong growth }\end{array}$} \\
\hline & & 2015 & 2030 & 2050 & 2015 & 2030 & 2050 & 2015 & 2030 & 2050 \\
\hline \multicolumn{11}{|l|}{ Aluminium sector } \\
\hline Alumina & 2.9 & 3.8 & 5.8 & 7.3 & 4.0 & 7.4 & 9.7 & 4.0 & 6.6 & 8.8 \\
\hline Primary aluminium & 1.2 & 2.0 & 6.5 & 11.0 & 2.0 & 10.9 & 17.5 & 2.9 & 11.3 & 20.2 \\
\hline Recycled aluminium* & 1.0 & 2.5 & 8.6 & 14.6 & 2.8 & 15.1 & 25.0 & 3.7 & 15.8 & 28.0 \\
\hline
\end{tabular}

*Recycled aluminium includes all scrap (fabricator, traded new, old)

Table A.3: Materials production in the BLUE Scenario, Mt

\begin{tabular}{|c|c|c|c|c|c|c|c|c|c|c|}
\hline & \multirow[b]{2}{*}{2007} & \multicolumn{3}{|c|}{$\begin{array}{c}\text { BLUE } \\
\text { low-demand }\end{array}$} & \multicolumn{3}{|c|}{$\begin{array}{c}\text { BLUE } \\
\text { high-demand }\end{array}$} & \multicolumn{3}{|c|}{$\begin{array}{c}\text { BLUE } \\
\text { strong growth }\end{array}$} \\
\hline & & 2015 & 2030 & 2050 & 2015 & 2030 & 2050 & 2015 & 2030 & 2050 \\
\hline \multicolumn{11}{|l|}{ Iron and steel sector } \\
\hline Crude steel & 53 & 131 & 200 & 266 & 169 & 242 & 355 & 189 & 361 & 550 \\
\hline Iron BF & 29 & 99 & 150 & 190 & 134 & 184 & 242 & 141 & 253 & 344 \\
\hline Iron - smelt reduction & 0 & 0 & 7 & 25 & 0 & 15 & 50 & 0 & 15 & 50 \\
\hline DRI - gas based & 5 & 8 & 12 & 13 & 9 & 14 & 15 & 8 & 13 & 14 \\
\hline DRI - coal based & 13 & 11 & 7 & 2 & 8 & 0 & 0 & 10 & 7 & 1 \\
\hline Scrap availability & 10 & 25 & 40 & 57 & 32 & 48 & 76 & 44 & 102 & 183 \\
\hline \multicolumn{11}{|l|}{ Cement sector } \\
\hline Cement & 170 & 291 & 482 & 646 & 303 & 540 & 742 & 303 & 920 & 1656 \\
\hline Clinker-to-cement ratio & 0.84 & 0.77 & 0.72 & 0.71 & 0.76 & 0.72 & 0.69 & 0.76 & 0.71 & 0.71 \\
\hline
\end{tabular}




\begin{tabular}{|c|c|c|c|c|c|c|c|c|c|c|}
\hline & \multirow[b]{2}{*}{2007} & \multicolumn{3}{|c|}{$\begin{array}{c}\text { BLUE } \\
\text { low-demand }\end{array}$} & \multicolumn{3}{|c|}{$\begin{array}{c}\text { BLUE } \\
\text { high-demand }\end{array}$} & \multicolumn{3}{|c|}{$\begin{array}{c}\text { BLUE } \\
\text { strong growth }\end{array}$} \\
\hline & & 2015 & 2030 & 2050 & 2015 & 2030 & 2050 & 2015 & 2030 & 2050 \\
\hline \multicolumn{11}{|c|}{ Chemicals and petrochemicals } \\
\hline Ethylene & 3 & 5 & 9 & 16 & 6 & 14 & 25 & 7 & 20 & 36 \\
\hline Propylene & 2 & 3 & 5 & 9 & 4 & 8 & 13 & 4 & 11 & 21 \\
\hline $\begin{array}{l}\text { Benzene, Toluene, } \\
\text { Xylene (BTX) }\end{array}$ & 5 & 6 & 9 & 15 & 7 & 13 & 20 & 8 & 19 & 34 \\
\hline Ammonia & 13 & 17 & 24 & 30 & 19 & 26 & 33 & 21 & 32 & 47 \\
\hline Methanol & 0.1 & 0.2 & 0.4 & 0.8 & 0.2 & 0.5 & 1.0 & 0.2 & 0.6 & 1.4 \\
\hline \multicolumn{11}{|l|}{ Pulp and paper sector } \\
\hline Pulp & 4 & 6 & 8 & 11 & 7 & 12 & 19 & 6 & 10 & 16 \\
\hline Chemical wood pulp & 2 & 3 & 5 & 8 & 4 & 10 & 16 & 3 & 7 & 11 \\
\hline Mechanical wood pulp & 0 & 1 & 1 & 1 & 1 & 1 & 1 & 1 & 1 & 3 \\
\hline Other fibre pulp & 2 & 2 & 2 & 2 & 2 & 2 & 2 & 2 & 2 & 2 \\
\hline Paper and paperboard & 8 & 17 & 38 & 81 & 22 & 67 & 148 & 23 & 95 & 232 \\
\hline $\begin{array}{l}\text { Household and } \\
\text { sanitary paper }\end{array}$ & 0 & 0 & 3 & 6 & 1 & 5 & 11 & 1 & 7 & 18 \\
\hline Newsprint & 1 & 2 & 4 & 7 & 3 & 9 & 17 & 3 & 10 & 24 \\
\hline $\begin{array}{l}\text { Printing and } \\
\text { writing paper }\end{array}$ & 3 & 6 & 12 & 25 & 8 & 21 & 44 & 8 & 30 & 70 \\
\hline $\begin{array}{l}\text { Wrapping, Packaging } \\
\text { paper and board }\end{array}$ & 3 & 8 & 17 & 38 & 9 & 29 & 68 & 10 & 43 & 108 \\
\hline $\begin{array}{l}\text { Paper and } \\
\text { paperboard NES }\end{array}$ & 1 & 1 & 2 & 4 & 1 & 4 & 8 & 1 & 5 & 12 \\
\hline \multicolumn{11}{|l|}{ Aluminium sector } \\
\hline Alumina & 2.9 & 3.7 & 5.5 & 6.6 & 3.9 & 7.0 & 8.7 & 4.0 & 6.8 & 8.6 \\
\hline Primary aluminium & 1.2 & 1.9 & 6.2 & 9.9 & 2.0 & 10.3 & 15.7 & 2.9 & 11.6 & 19.8 \\
\hline Recycled aluminium* & 1.0 & 2.5 & 8.8 & 15.1 & 2.9 & 15.4 & 26.0 & 3.7 & 16.2 & 29.7 \\
\hline
\end{tabular}

*Recycled aluminium includes all scrap (fabricator, traded new, old) 
Table A.4: Final energy use in industry in the Baseline Scenario, Mtoe

\begin{tabular}{|c|c|c|c|c|c|c|c|c|c|c|}
\hline & \multirow[b]{2}{*}{2007} & \multicolumn{3}{|c|}{$\begin{array}{c}\text { Baseline } \\
\text { low-demand }\end{array}$} & \multicolumn{3}{|c|}{$\begin{array}{c}\text { Baseline } \\
\text { high-demand }\end{array}$} & \multicolumn{3}{|c|}{$\begin{array}{c}\text { Baseline } \\
\text { strong growth }\end{array}$} \\
\hline & & 2015 & 2030 & 2050 & 2015 & 2030 & 2050 & 2015 & 2030 & 2050 \\
\hline Aluminium & 3 & 4 & 11 & 16 & 4 & 17 & 25 & 6 & 17 & 28 \\
\hline Cement & 13 & 21 & 32 & 42 & 21 & 36 & 48 & 21 & 59 & 105 \\
\hline Chemicals and petrochemicals & 27 & 39 & 57 & 83 & 44 & 78 & 126 & 47 & 100 & 165 \\
\hline Iron and steel & 38 & 87 & 133 & 173 & 105 & 152 & 211 & 111 & 200 & 286 \\
\hline Pulp and paper & 3 & 6 & 10 & 19 & 7 & 17 & 33 & 7 & 21 & 47 \\
\hline Other & 66 & 70 & 131 & 191 & 70 & 131 & 191 & 70 & 131 & 191 \\
\hline Total & 150 & 226 & 373 & 524 & 252 & 430 & 634 & 262 & 527 & 822 \\
\hline
\end{tabular}

Table A.5: Final energy use in industry in the BLUE Scenario, Mtoe

\begin{tabular}{|c|c|c|c|c|c|c|c|c|c|c|}
\hline & \multirow[b]{2}{*}{2007} & \multicolumn{3}{|c|}{$\begin{array}{c}\text { BLUE } \\
\text { low-demand }\end{array}$} & \multicolumn{3}{|c|}{$\begin{array}{c}\text { BLUE } \\
\text { high-demand }\end{array}$} & \multicolumn{3}{|c|}{$\begin{array}{c}\text { BLUE } \\
\text { strong growth }\end{array}$} \\
\hline & & 2015 & 2030 & 2050 & 2015 & 2030 & 2050 & 2015 & 2030 & 2050 \\
\hline Aluminium & 3 & 4 & 10 & 14 & 4 & 14 & 20 & 6 & 17 & 26 \\
\hline Cement & 13 & 20 & 33 & 49 & 20 & 36 & 55 & 21 & 62 & 126 \\
\hline Chemicals and petrochemicals & 27 & 37 & 52 & 74 & 42 & 67 & 100 & 45 & 94 & 153 \\
\hline Iron and steel & 38 & 70 & 98 & 122 & 84 & 113 & 153 & 91 & 152 & 209 \\
\hline Pulp and paper & 3 & 5 & 9 & 17 & 7 & 15 & 31 & 6 & 19 & 43 \\
\hline Other & 66 & 63 & 99 & 126 & 63 & 101 & 134 & 63 & 99 & 126 \\
\hline Total & 150 & 199 & 301 & 402 & 221 & 347 & 492 & 231 & 443 & 685 \\
\hline
\end{tabular}


Table A.6: Direct $\mathrm{CO}_{2}$ emissions in industry in the Baseline Scenario, $\mathrm{Mt} \mathrm{CO}_{2}$

\begin{tabular}{|c|c|c|c|c|c|c|c|c|c|c|}
\hline & \multirow[b]{2}{*}{2007} & \multicolumn{3}{|c|}{$\begin{array}{c}\text { Baseline } \\
\text { low-demand }\end{array}$} & \multicolumn{3}{|c|}{$\begin{array}{c}\text { Baseline } \\
\text { high-demand }\end{array}$} & \multicolumn{3}{|c|}{$\begin{array}{c}\text { Baseline } \\
\text { strong growth }\end{array}$} \\
\hline & & 2015 & 2030 & 2050 & 2015 & 2030 & 2050 & 2015 & 2030 & 2050 \\
\hline Aluminium & 4 & 5 & 10 & 14 & 6 & 15 & 21 & 6 & 15 & 22 \\
\hline Cement & 128 & 206 & 322 & 422 & 214 & 358 & 483 & 213 & 596 & 1060 \\
\hline Chemicals and petrochemicals & 48 & 72 & 100 & 132 & 80 & 122 & 173 & 85 & 152 & 229 \\
\hline Iron and steel & 151 & 351 & 538 & 703 & 425 & 615 & 858 & 448 & 805 & 1153 \\
\hline Pulp and paper & 8 & 13 & 21 & 36 & 15 & 33 & 62 & 14 & 40 & 87 \\
\hline Other & 74 & 60 & 149 & 256 & 60 & 149 & 256 & 60 & 149 & 256 \\
\hline Total & 413 & 707 & 1140 & 1564 & 799 & 1291 & 1852 & 828 & 1757 & 2807 \\
\hline
\end{tabular}

Table A.7: Direct $\mathrm{CO}_{2}$ emissions in industry in the BLUE Scenario, $\mathrm{Mt} \mathrm{CO}_{2}$

\begin{tabular}{|c|c|c|c|c|c|c|c|c|c|c|}
\hline & \multirow[b]{2}{*}{2007} & \multicolumn{3}{|c|}{$\begin{array}{c}\text { BLUE } \\
\text { low-demand }\end{array}$} & \multicolumn{3}{|c|}{$\begin{array}{c}\text { BLUE } \\
\text { high-demand }\end{array}$} & \multicolumn{3}{|c|}{$\begin{array}{c}\text { BLUE } \\
\text { strong growth }\end{array}$} \\
\hline & & 2015 & 2030 & 2050 & 2015 & 2030 & 2050 & 2015 & 2030 & 2050 \\
\hline Aluminium & 4 & 5 & 9 & 12 & 5 & 12 & 16 & 6 & 15 & 22 \\
\hline Cement & 128 & 191 & 265 & 275 & 195 & 284 & 291 & 198 & 488 & 676 \\
\hline Chemicals and petrochemicals & 48 & 61 & 66 & 68 & 68 & 73 & 77 & 72 & 99 & 119 \\
\hline Iron and steel & 151 & 280 & 338 & 333 & 337 & 368 & 362 & 360 & 501 & 532 \\
\hline Pulp and paper & 8 & 9 & 11 & 17 & 11 & 17 & 31 & 10 & 23 & 50 \\
\hline Other & 74 & 59 & 99 & 122 & 60 & 101 & 129 & 59 & 99 & 122 \\
\hline Total & 413 & 605 & 788 & 827 & 675 & 856 & 906 & 705 & 1226 & 1519 \\
\hline
\end{tabular}




\section{Annex B. Indicators for the chemical and petrochemical sector}

Best practice technology (BPT) values in Table B.1 are plant-specific net energy requirements expressed as lower heating values. They refer to the core process excluding options for heat cascading and the process integration of material flows in individual plants on a site and for combined heat and power (CHP) systems. Steam exports from production processes with exothermic reactions, such as steam from steam cracking and from ammonia production, are expressed as negative values. This approach assumes that all excess heat can be used on site.

This table also reports electricity use, although the potential for energy efficiency has been established only for fuels, including steam. Only one-third of total electricity use in the chemicals and petrochemicals sector can be accounted for by bottom-up energy analysis using process energy data (IEA, 2009a). The remainder is probably used to run pumping equipment for pipelines and tanks and auxiliary uses for which no detailed data are available. The overall short- to medium-term savings potential in electricity use in the sector has been estimated at 20\% (IEA, 2009a).

Feedstock consumption is estimated by means of the calorific value of the chemicals resulting from the first conversion of fossil fuels to chemicals such as benzene, ethylene and propylene. These chemicals are raw materials used in the production of intermediates and their derivatives. To avoid counting them twice, the calorific values of intermediates and derivatives are excluded. As a result, it is not possible to attribute any improvements in energy efficiency to the feedstock used for the production of organic chemicals.

The system boundaries of the data used in this analysis can be described as "factory gate to factory gate". For example, for steam cracking the data refer to the conversion of naphtha to olefins. For an intermediate chemical such as ethylene oxide, the data cover only the conversion of ethylene to ethylene oxide, excluding the raw materials and energy used in upstream processes.

Processes that result in several products are common in the chemicals and petrochemical sector. They represent a particular challenge when modelling energy use and carbon dioxide $\left(\mathrm{CO}_{2}\right)$ emissions. This is especially the case for steam cracking, which is by far the largest multi-product process in this sector. In this annex we use the definition of high-value chemicals (HVCs) used by Solomon Associates (who are known for their benchmark studies on steam cracking). According to this definition, HVCs include ethylene, propylene from the pyrolysis gas of steam crackers, benzene (contained amounts, excluding extracted amounts), butadiene (also contained), acetylene and hydrogen (sold as fuel). Unlike the previous IEA publication (2008a), in this current analysis toluene and xylene have not been included in the definition of HVCs.

The average fuel use of a BPT steam cracker is 13.1 gigajoules per tonne (GJ/t) of HVCs. This value, shown in Table B.1, covers all steam cracker HVCs. The product of this value and the production volumes of HVCs results in a figure for the total BPT fuel use (in petajoules [PJ]) of steam crackers. The same calculation is repeated for steam, electricity and feedstock in order to calculate the total energy use of steam crackers. 
Table B.1: BPT values on the specific energy consumption for the production of key chemicals (left: in final energy terms, denoted with index "f"; right: in primary energy terms, denoted with index " $p$ ")

\begin{tabular}{|c|c|c|c|c|c|c|c|c|c|}
\hline \multirow{2}{*}{ Process } & \multicolumn{4}{|c|}{ In final energy terms $\left(G^{\prime} J_{f} / t\right)$} & \multicolumn{4}{|c|}{ In primary energy terms $\left(\mathrm{GJ}_{\mathrm{p}} / \mathrm{t}\right)$} & \multirow{2}{*}{ Source } \\
\hline & Electricity & Feedstock & Fuel & Steam & Electricity & Feedstock & Fuel & Steam & \\
\hline \multicolumn{10}{|l|}{ Organic } \\
\hline Acetic acid & 0.46 & & & 4.11 & 1.16 & & & 4.57 & Meyers, 2004 \\
\hline Acetone & 0.20 & & & 9.77 & 0.50 & & & 10.86 & Chauvel and Lefebvre, 1989 \\
\hline Acrylonitrile (ACN) & 0.84 & & 0.30 & -6.39 & 2.10 & & 0.30 & -7.10 & Schyns, 2006 \\
\hline Adipic acid $^{2}$ & 0.46 & & 0.96 & 18.51 & 1.15 & & 0.96 & 20.57 & Chauvel and Lefebvre, 1989 \\
\hline Benzene (steam cracking) & 0.28 & 0 & 13.10 & -1.37 & 0.70 & 0 & 13.10 & -1.52 & Schyns, 2006 \\
\hline Benzene (aromatics extraction) & 0.06 & 45 & & 1.98 & 0.14 & 45 & & 2.20 & Schyns, 2006 \\
\hline Butadiene (steam cracking) & 0.28 & 0 & 13.10 & -1.37 & 0.70 & 0 & 13.10 & -1.52 & Schyns, 2006 \\
\hline Butadiene ( $\mathrm{C}_{4}$ separation) & 0.52 & 45 & & 6.73 & 1.30 & 45 & & 7.48 & Schyns, 2006 \\
\hline Butylene & 0.06 & 45 & & 1.98 & 0.14 & 45 & & 2.20 & Schyns, 2006 \\
\hline Caprolactam & 1.05 & & 0.20 & -3.24 & 2.63 & & 0.20 & -3.60 & Schyns, 2006 \\
\hline Cumene & 0.00 & & 2.05 & -2.80 & 0.00 & & 2.05 & -3.11 & Meyers, 2004 \\
\hline Cyclohexane $^{2}$ & 0.08 & & & -1.63 & 0.19 & & & -1.81 & Industrial sources \\
\hline Dimethyl terephthalate (DMT) ${ }^{2}$ & 0.02 & & 4.72 & & 0.04 & & 4.72 & & Industrial sources \\
\hline Diphenylmethane diisocyanate (MDI) ${ }^{2}$ & 3.20 & & & 0.90 & 8.00 & & & 1.00 & Industrial sources \\
\hline Ethanol $^{2,3}$ & 0.80 & & & 22.21 & 2.00 & & & 23.13 & BREW Study, 2006 \\
\hline Ethylene $^{4}$ & 0.28 & 45 & 13.10 & -1.37 & 0.70 & 45 & 13.10 & -1.52 & Schyns, 2006 \\
\hline Ethylbenzene (EB) & 0.07 & & & 3.28 & 0.18 & & & 3.64 & Meyers, 2004 \\
\hline Ethylene dichloride (EDC) & 0.23 & & 4.42 & & 0.58 & & 4.42 & & IEA estimates \\
\hline Ethylene glycol (EG) ${ }^{2}$ & 0.21 & & 0.75 & 3.50 & 0.52 & & 0.75 & 3.88 & Industrial sources \\
\hline Ethylene oxide (EO) ${ }^{2}$ & 0.82 & & 2.47 & & 2.04 & & 2.47 & & Industrial sources \\
\hline Formaldehyde $^{5}$ & 0.77 & & & -4.77 & 1.93 & & & -5.30 & IPTS, 2003 \\
\hline Isopropyl alcohol (IPA) & 0.09 & & 5.20 & 5.40 & 0.23 & & 5.20 & 6.00 & Chauvel and Lefebvre, 1989 \\
\hline Maleic anhydride & 0.11 & & & 2.00 & 0.28 & & & 2.22 & IEA estimates \\
\hline
\end{tabular}

\section{Acetone}

Benzene (steam cracking)

Benzene (aromatics extraction)

Butadiene ( $\mathrm{C}_{4}$ separation)

Butylene

Cyclohexane

Ethylene

thylbenzene (EB)

Formaldehyde

Maleic anhydride 


\begin{tabular}{|c|c|c|c|c|c|c|c|c|c|}
\hline \multirow{2}{*}{ Process } & \multicolumn{4}{|c|}{ In final energy terms $\left(G_{\mathbf{f}} / \mathbf{t}\right)$} & \multicolumn{4}{|c|}{ In primary energy terms $\left(G_{\mathrm{p}} / \mathrm{t}\right)$} & \multirow{2}{*}{ Source } \\
\hline & Electricity & Feedstock & Fuel & Steam & Electricity & Feedstock & Fuel & Steam & \\
\hline Melamine $^{5}$ & 1.89 & & 7.90 & 3.87 & 4.73 & & 7.90 & 4.30 & Schyns, 2006 \\
\hline Methacrylate & 0.11 & & & 2.00 & 0.28 & & & 2.22 & IEA estimates \\
\hline Methanol from natural gas ${ }^{6}$ & & 20 & & 8.50 & & 20 & & 9.44 & IEA estimates \\
\hline Methanol from coal ${ }^{6}$ & & 20 & & 12.75 & & 20 & & 16.06 & IEA estimates \\
\hline Methyl tertiary butyl ether (MTBE) & 0.05 & & & 0.84 & 0.13 & & & 0.93 & Schyns, 2006 \\
\hline Oxo alcohols & 2.48 & & & 2.31 & 1.0 & & & 2.08 & Meyers, 2004 \\
\hline Phenol & 0.60 & & & 9.10 & 1.50 & & & 10.11 & Meyers, 2004 \\
\hline Phthalic anhydride & 0.70 & & 20.00 & & 1.75 & & 20.00 & & IEA estimates \\
\hline Propylene (steam cracking) & 0.28 & 45 & 13.10 & -1.37 & 0.70 & 45 & 13.10 & -1.52 & Schyns, 2006 \\
\hline Propylene (FCC) $)^{\prime}$ & 0.06 & 45 & & 1.98 & 0.14 & 45 & & 2.20 & Schyns, 2006 \\
\hline Propylene oxide $^{2}$ & 0.84 & & & 14.24 & 2.10 & & & 15.82 & Industrial sources \\
\hline Purified terephthalic acid (PTA) & 0.30 & & & 2.60 & 0.75 & & & 2.89 & Meyers, 2004 \\
\hline Styrene & & & & 7.70 & & & & 8.56 & JPCA, 2009 \\
\hline Toluene (aromatics extraction) & 0.06 & 22.5 & & 1.98 & 0.14 & 22.5 & & 2.20 & Schyns, 2006 \\
\hline Toluene diisocyanate (TDI) $^{5}$ & 2.80 & & & 21.70 & 7.00 & & & 24.11 & Schyns, 2006 \\
\hline Xylene (aromatics extraction) & 0.06 & 45 & & 1.98 & 0.14 & 45 & & 2.20 & IEA estimates \\
\hline p-Xylene & 0.20 & & 6.30 & 0.80 & 0.50 & & 6.30 & 0.89 & Schyns, 2006 \\
\hline Vinyl acetate monomer ${ }^{2}$ & 0.48 & & & 3.80 & 1.20 & & & 4.22 & Industrial sources \\
\hline Vinyl chloride monomer & 0.40 & & 2.70 & & 1.00 & & 2.70 & & Meyers, 2004 \\
\hline Urea & 0.26 & & & 2.20 & 0.64 & & & 2.45 & Schyns, 2006 \\
\hline \multicolumn{10}{|l|}{ Plastics } \\
\hline Phenolic resins $^{5}$ & & & & 10.00 & & & & 11.11 & IEA estimates \\
\hline Polycarbonate & 2.16 & & & 10.32 & & & & 11.47 & Schyns, 2006 \\
\hline Polyethylene, high density (HDPE) & 0.86 & & & 0.99 & 2.15 & & & 1.10 & Schyns, 2006 \\
\hline Polyethylene, low density (LDPE) & 3.50 & & & -2.14 & 8.75 & & & -2.38 & Schyns, 2006 \\
\hline Polyethylene, linear low density (LLDPE) & 0.44 & & & 1.64 & 1.10 & & & 1.82 & IPTS, 2007a \\
\hline
\end{tabular}




\begin{tabular}{|c|c|c|c|c|c|c|c|c|c|}
\hline \multirow{2}{*}{ Process } & \multicolumn{4}{|c|}{ In final energy terms $\left(\mathbf{G J}_{\mathrm{t}} / \mathrm{t}\right)$} & \multicolumn{4}{|c|}{ In primary energy terms $\left(\mathbf{G J}_{\mathrm{p}} / \mathrm{t}\right)$} & \multirow{2}{*}{ Source } \\
\hline & Electricity & Feedstock & Fuel & Steam & Electricity & Feedstock & Fuel & Steam & \\
\hline Polyethylene terephthalate (PET) & 0.70 & & 4.10 & & 1.75 & & 4.10 & & Boustead, 2008 \\
\hline Polypropylene (PP) & 0.86 & & & 0.10 & 2.16 & & & 0.11 & Schyns, 2006 \\
\hline Polystyrene (PS) & 0.40 & & 0.50 & & 1.00 & & 0.50 & & Hydrocarbons Processing, 2003 \\
\hline Polyvinyl chloride (PVC) & 0.64 & & 0.51 & 1.22 & 1.60 & & 0.51 & 1.36 & Schyns, 2006 \\
\hline Urea formaldehyde (UF) \& other resins \& fibres ${ }^{2,9}$ & 0.16 & & & 2.00 & 0.50 & & & 2.78 & Industrial sources \\
\hline Synthetic rubber \& latex ${ }^{9}$ & 2.47 & & & 19.91 & 6.17 & & & 22.12 & Schyns, 2006 \\
\hline \multicolumn{10}{|l|}{ Inorganic } \\
\hline Ammonia from natural gas ${ }^{6}$ & 0.29 & 20.67 & 10.93 & -3.87 & 0.74 & 20.67 & 10.93 & -4.30 & Schyns, 2006 \\
\hline Ammonia from coal ${ }^{6}$ & 3.70 & 20.67 & 17.33 & -1.30 & 9.25 & 20.67 & 17.33 & -1.44 & AlChE, 2008; IFA, 2009b \\
\hline Ammonia from oil ${ }^{6}$ & 0.50 & 20.67 & 16.13 & -1.50 & 0.74 & 20.67 & 16.13 & -1.67 & IFA, 2009b \\
\hline Carbon black $^{10}$ & 1.80 & 32.8 & & & 4.50 & 32.8 & & & Leenderste and van Veen, 2002 \\
\hline Chlorine $^{11}$ & 10.00 & & & 1.85 & 25.00 & & & 2.06 & IPTS, 2001; Gielen, 1997 \\
\hline Oxygen & 0.64 & & & & 1.6 & & & & IEA estimates \\
\hline Soda ash ${ }^{12}$ & & & & 10.00 & & & & 11.11 & IPTS, 2004 \\
\hline Titanium dioxide $^{13}$ & 2.80 & & 4.10 & 8.40 & 7.00 & & 4.10 & 9.33 & IPTS, 2007b \\
\hline
\end{tabular}

1 Final energy has been converted to primary energy assuming a steam production efficiency of $90 \%$ and a power generation efficiency of $40 \%$.

2 Where BPT values are not available, BPTs are assumed to be capable of achieving a $20 \%$ saving on current specific energy use values.

3 The value for steam use (22.21 gigajoules of fuel per tonne [GJf/t]) includes both the production of ethanol from fermentable sugar (13.89 $\mathrm{GJf} / \mathrm{t})$ and the production of fermentable sugar from agricultural crops ( $8.32 \mathrm{GJf} / \mathrm{t})$.

4 This dataset has been used for all ethylene production except ethylene production by steam cracking of ethane, for which the fuel use is estimated to be $5 \mathrm{GJ} / \mathrm{t}$ higher.

5 No feedstock value is given for formaldehyde, melamine, TDI and phenolic resins because this has already been accounted for in the production of the relevant raw materials.

6 Natural gas feedstock assumed for all countries except India and China where coal (final energy use assumed to be $50 \%$ higher than natural gas) and oil (final energy use assumed to be $30 \%$ higher than natural gas) are widely used as feedstock.

7 Approximated using the dataset for aromatics extraction.

8 The feedstock value of toluene is corrected by the share of its consumption $(\sim 50 \%)$, which is further processed to other aromatics.

9 The BPT for urea formaldehyde (UF) resin production only, but used for the entire product group.

10 Net energy requirements. This means that released energy in the form of steam or power is credited.

11 For one tonne of chlorine production, but covers the electrolysis of sodium chloride as a whole, i.e. including the concentration of sodium hydroxide to $50 \%$ concentration. Steam use for brine preparation and sodium hydroxide $(\mathrm{NaOH})$ concentration is accounted for as well as power requirements for rectifiers. Power required for $\mathrm{NaOH}$ cooling, hydrogen cooling and drying, liquefaction/evaporation of chlorine and its gas compression are excluded from the system boundaries. For the by-product hydrogen, no credits are given (approximately $3.4 \mathrm{GJ} / \mathrm{t}-\mathrm{Cl} 2$ based on the lower heating value (LHV) of hydrogen by-produced).

12 Synthetic production only, i.e. excluding any potential savings from soda ash production in the United States and Canada.

13 The lowest recorded energy use of the chloride process route. 


\section{Annex C. References}

ACR (2008), India's Pulp \& Paper Industry Must Seek Global competitiveness through Automation System and Enter prise Solution Investments.

www.arcweb.com/Regions/Asia/Lists/Posts/Post.aspx?List=d954eb0a\%2D8950\%2D46e8\%2D86f7\%2D433f $68 \mathrm{e} 9 \mathrm{cf} 4 \mathrm{~b} \& \mid \mathrm{D}=59$

AITEC (Associazione Italiana Tecnico Economica Cemento) (2000 to 2008), Annual Report, AITEC, Rome.

Bayliss, C. and J. Marks (2008), The Aluminium Industry, presentation to the IEA/ERI Workshop on International comparison of Industrial Energy Efficiency, Beijing.

Battelle (2002), Toward a Sustainable Cement Industry, Climate Change, WBCSD, Geneva.

www.wbcsd.org

BEE (India Bureau of Energy Efficiency) (2008), Textile Sector.

www.bee-india.nic.in/sector/textile/001.zip

CEPI (Confederation of European Paper Industries) (2006), Europe Global Champion in Paper Recycling: Paper Industries Meet Ambitious Target, Press Release, July, Brussels.

Chemweek (2007a), Product Focus: Carbon Black, 31 January.

Chemweek (2007b), Product Focus: Chlor-Alkali, 25 April.

Chemweek (2007c), Product Focus: Polycarbonate, 28 November-5 December.

Chemweek (2007d), Product Focus: Titanium Dioxide, 14-21 February.

CPPRI (Central Pulp and Paper Research Institute (2006), Development of energy consumption norms for pulp and paper industry under Energy conservation act - 2001, CPPRI, Saharanpur, 2006.

CSI (Cement Sustainability Initiative) (2008), Getting the Numbers Right database, WBCSD, Geneva.

European Environment Agency (2006), Annual European Community Greenhouse Gas Inventory 1990-2004 and Inventory Report 2006, European Commission, Brussels

EC (2008), IPCC Draft Reference Document on Best Available Techniques in the Non-Ferrous Metals Industry, European Commission, Brussels/Seville.

ftp.jrc.es/eippcb/doc/nfm_2d_07-2009_public.pdf

Gol (Government of India) (2008), Continuation of Scheme for Integrated Textiles Parks during 11th Plan.

pib.nic.in/release/release. asp? relid=36684

Gol Textiles Committee (2003), Status of powerloom sector in Tamil Nadu - Focus on modernisation. Mumbai: Government of India.

IAI (International Aluminium Institute) (2007), Life Cycle Assessment of Aluminium: Inventory Data for the Primary Aluminium Industry, year 2005 update, International Aluminium Institute.

www.world-aluminium.org/cache/fl0000166.pdf

IAI (2009a), Historical IAI statistics.

www.world-aluminium.org/Statistics/Historical+statistics

IAI (2009b), Fourth Sustainable Bauxite Mining Report.

www.world-aluminium.org/cache/fl0000292.pdf

IAI (2009c), Global Aluminium Recycling: A Cornerstone of Sustainable Development. 
http://www.world-aluminium.org/cache/fl0000181.pdf

IAI (2009d), Results of the 2008 Anode effect survey, Report on the Aluminium Industry's Global Perfluorocarbon Gases Emissions Reduction Programme, IAI, London.

IBEF (India Brand Equity Foundation) (2009a), Cement Industry, August 2009.

www.ibef.org/industry/cement.aspx

IBEF (2009b), Textiles.

http://ibef.org/industry/textiles.aspx

IBGE (Instituto Brasileiro de Geofrafia e Estatistics) (2008), Cement Sector Energy Consumption Statistics, IBGE, Brasilia.

ICRA (2006). The Indian cement industry. July 2006.

www.icra.in

IEA (International Energy Agency) (2007), Tracking Industrial Energy Efficiency and $\mathrm{CO}_{2}$ Emissions, OECD/IEA, Paris.

www.iea.org/w/bookshop/add.aspx?id=298

IEA (2008a), Energy Technology Perspectives 2008, Scenarios \& Strategies to 2050, IEA/OECD, Paris.

www.iea.org/w/bookshop/add.aspx?id=330

IEA (2008b), Energy Statistics of OECD Countries, 2008 Edition, IEA/OECD, Paris.

IEA (2008c), Energy Balances of OECD Countries, 2008 Edition, IEA/OECD, Paris.

IEA (2008d), Energy Balances of Non-OECD Countries, 2008 Edition, IEA/OECD, Paris.

IEA (2008e), CHP and District Cooling: An Assessment of Market and Policy Potential in India, The International CHP/DHC Collaborative, IEA/OECD, Paris.

IEA (2009a), Energy Technology Transitions for Industry, Strategies for the Next Industrial Revolution, IEA/OECD, Paris.

www.iea.org/w/bookshop/add.aspx?id=354

IEA (2009b), Energy Balances of OECD Countries, 2009 Edition, IEA/OECD, Paris.

www.iea.org/w/bookshop/add. aspx?id=29

IEA (2009c), Energy Balances of Non-OECD Countries, 2009 Edition, IEA/OECD, Paris.

www.iea.org/w/bookshop/add.aspx?id=31

IEA (2009d), Chemical and Petrochemical Sector: Potential of best practice technology and other measures for improving energy efficiency, IEA information paper, IEA/OECD, Paris.

www.iea.org/publications/free_new_Desc.asp?PUBS_ID=2138

IEA (2009e), $\mathrm{CO}_{2}$ Emissions from Fuel Combustion, 2009 Edition, IEA/OECD, Paris.

www.iea.org/w/bookshop/add.aspx?id=36

IFA (International Fertilizers Association) (2009), Urea production for year 2006, personal communication, IFA.

INEGI (Instituto nacional de Estadistics Geografia e Informatica) (2008), Balance Nacional de Energia, INEGI, Mexico City.

IPCC (Intergovernmental Panel on Climate Change) (2007), Climate Change 2007: Mitigation of Climate Change: Contribution of Working Group III to the Fourth Assessment Report of the Intergovernmental 
Panel on Climate Change [B. Metz, et al. (eds.)], Cambridge University Press, Cambridge, UK and New York.

ISR (2000), Energy Efficiency Best Practices in the Australian Aluminium Industry, Department of Industry, Science and Resources, Canberra.

JCA (Japan Cement Association) (2006), Cement Industry's Status and Activities for GHG Emissions Reduction in Japan, presentation to the IEA-WBCSD Workshop on Energy Efficiency and $\mathrm{CO}_{2}$ Emission Reduction Potentials and Policies in the Cement Industry, IEA, Paris, September.

Keniry, J. (2001), The economics of Inert Anodes and Wettable Cathodes for Aluminium Reduction Cells, JOM Journalof the Minerals, Metals and Materials Society, Volume 53, Number 5, pp 43-47.

Metalworld (2008), Expansion on Cards for the Aluminium Industries in India, Metalworld Journal, Mumbai.

www.metalworld.co.in/report0108.pdf

METI (Ministry of Economy, Trade and Industry) (2008), Personal Communication, April 16.

Nagesha, N. (2008), Role of energy efficiency in sustainable development of small-scale industry clusters: an empirical study, Energy for sustainable Development , 12 (3), 34-39.

NRCan (Natural Resources Canada) (2008), Comprehensive Energy Use Database, NRCan, Ottawa.

OECD (Organisation for Economic Co-operation and Development) (2008), The Financial Crisis and Outlook for Steel, DSTI/SU/SC (2008)37, OECD, Paris.

OFICEMEN (2007), Statistics of the Spanish Cement Industry.

www.oficemen.com

Palanichamy, C., \& Babu, N. S. (2005). Second stage energy conservation experience with a textile industry, Energy policy, 603-609.

PCA (Portland Cement Association) (2008), North American Cement Industry Annual Yearbook, Skokie, Illinois.

PlasticsEurope (2008), The Compelling Facts About Plastics 2007, an analysis of plastic production, demand and recovery for 2007 in Europe, Brussels, October.

RFA (Renewable Fuels Association (2009), Statistics.

www.ethanolrfa.org/industry/statistics

SAIL (Steel Authority of India Limited) (2005), India-Canada cooperation for Clean Development Mechanism, presentation to TERI, New Delhi, 6 September 2005.

Siam Cement Company Ltd. (2005) Sustainable Development Report 2005, Siam Cement Company Ltd, Bangkok.

Schumacher, K. J. Sathaye (1999), India's pulp and paper industry: Productivity and energy efficiency, Lawrence Berkeley National Laboratory, LBNL-41843.

Schyns, V. (2006), Towards a Simple, Robust and Predictable EU Emissions Trading Scheme, Benchmarks from Concrete to Practice, Utility Support Group, Geleen, the Netherlands.

Soares, J.B. and M.T. Tolmasquim (2000), Energy Efficiency and Reduction of $\mathrm{CO}_{2}$ Emissions Through 2015: The Brazilian Cement Industry, Mitigation and Adaptation Strategies for Global Change No. 5, pp. 297318 , Netherlands.

SRI Consulting (2008), Production, Capacity and Capacity Average Age Data for selected chemicals and for selected countries and for OECD regions, Menlo Park, CA.

Tao Z. and X. Liang (2008) Energy Conservation and the Development of China's Electrolysis Aluminium Industry, presentation to the IEA/ERI Workshop on International Comparison of Industrial Energy Efficiency, Beijing. 
Tata Energy Research Institute. (2003).

TERI (The Energy Research Institute) (2006), TERI Energy Data Directory \& Yearbook, New Delhi, 2006.

USGS (United States Geological Survey) (2008a), 2007 Minerals Yearbook: Nitrogen [advance release], Reston, Virginia.

USGS (2008b), 2007 Minerals Yearbook: Soda ash [advance release], Reston, Virginia.

USGS (2008c), 2007 Minerals Yearbook: Cement, Reston, Virginia.

USGS (2009a), 2008 Minerals Yearbook: Cement [advance release], Reston, Virginia.

minerals.usgs.gov/minerals/pubs/commodity/cement/myb1-2007-cemen.pdf

USGS (2009b), 2008 Minerals Yearbook: Aluminum [advance release], Reston, Virginia.

minerals.usgs.gov/minerals/pubs/commodity/aluminum/myb1-2008-alumi.pdf

USGS (2009b), 2007 Minerals Yearbook: Bauxite and Alumina [advance release], Reston, Virginia.

http://minerals.usgs.gov/minerals/pubs/commodity/bauxite/myb1-2007-bauxi.pdf

VDEh (Stahl Institut VDEH) (2009), Steel Industry in Germany,

www.stahl-online.de/english/media_lounge/Lectures/start.asp

VDZ (Verein Deutscher Zementwerke e.V.) (2008), Activity Report 2005-2007, VDZ, Dusseldorf.

Worrell, E., L. Price, N. Martin, C. Hendriks, L.O. Meida, (2001), Carbon Dioxide Emissions from the Global Cement Industry, Annual Review of Energy and Environment, Vol 26, 2001.

Worrell, E., et al. (2008), World Best Practice Energy Intensity Values for Selected Industrial Sectors, Ernest Orlando Lawrence Berkeley National Laboratory, LBNL-62806 Rev2.

Worldsteel (World Steel Association) (2009), Steel Statistical Yearbook 2008, worldsteel Committee on Economic Studies, Brussels.

www.worldsteel.org/pictures/publicationfiles/SSY2008[1].pdf 


\section{Annex D. Abbreviations, acronyms and units}

${ }^{\circ} \mathrm{C} \quad$ degree Celsius

BAT best available technology

BF blast furnace

$\mathrm{BF} / \mathrm{BOF}$ blast furnace/Basic oxygen furnace

BIGCC biomass-integrated gasification with combined cycle

BOF basic oxygen furnace

BPT best practice technology

BTX Benzene, Toluene, Xylene

Cap Capita

CCS carbon capture and storage

CDM Clean development mechanism

CDQ coke dry quenching

$\mathrm{CHP}$ combined heat and power

$\mathrm{CO}_{2}$ carbon dioxide

COG coke oven gas

CWPB centre work pre-bake

DRI direct reduced iron

EAF electric arc furnace

EEI Energy Efficiency Index

EJ exajoules ( $10^{18}$ joules)

ETP Energy Technology Perspectives

GDP gross domestic product

GHG greenhouse gas

GJ gigajoules ( $10^{9}$ joules)

$\mathrm{GJ} / \mathrm{t} \quad$ gigajoules $\left(10^{9}\right.$ joules) per tonne

Gt gigatonnes

$\mathrm{Gt} / \mathrm{CO}_{2}$ gigatonnes of carbon dioxide

HSS horizontal stud Søderberg

HVC high-value chemicals

IAI International Aluminium Institute

IEA International Energy Agency

IPCC United Nations Intergovernmental Panel on Climate Change

$\mathrm{kg} \quad$ kilogram $\left(10^{3}\right.$ grammes)

$\mathrm{kg} / \mathrm{cap}$ kilogram per capita

$\mathrm{kg} / \mathrm{thm}$ kilogram per tonne of hot metal

$\mathrm{kt} / \mathrm{yr}$ thousands of tonners per year

ktoe thousands of tonnes of oil equivalent 


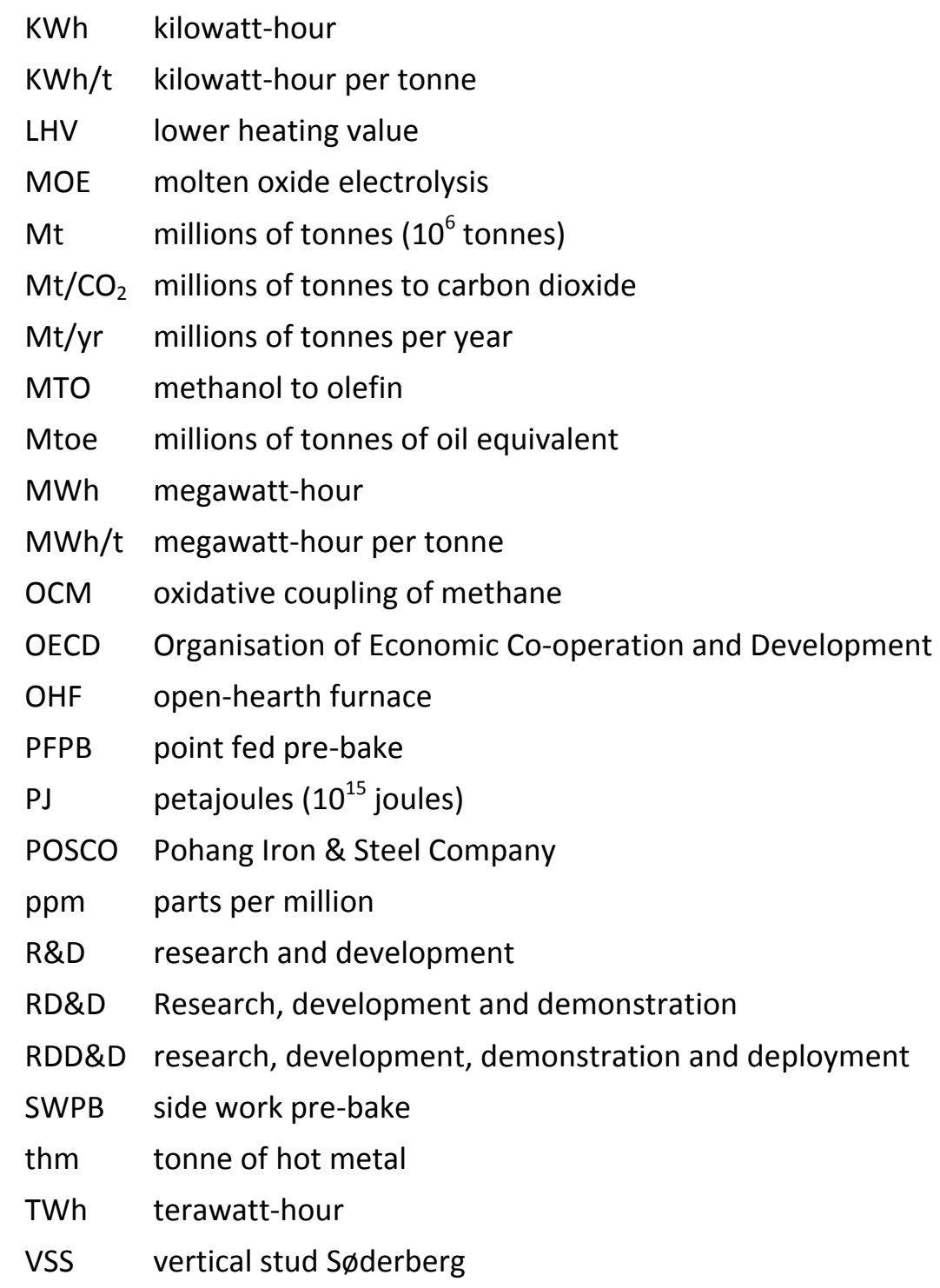




\section{iea}

\section{International Energy Agency}
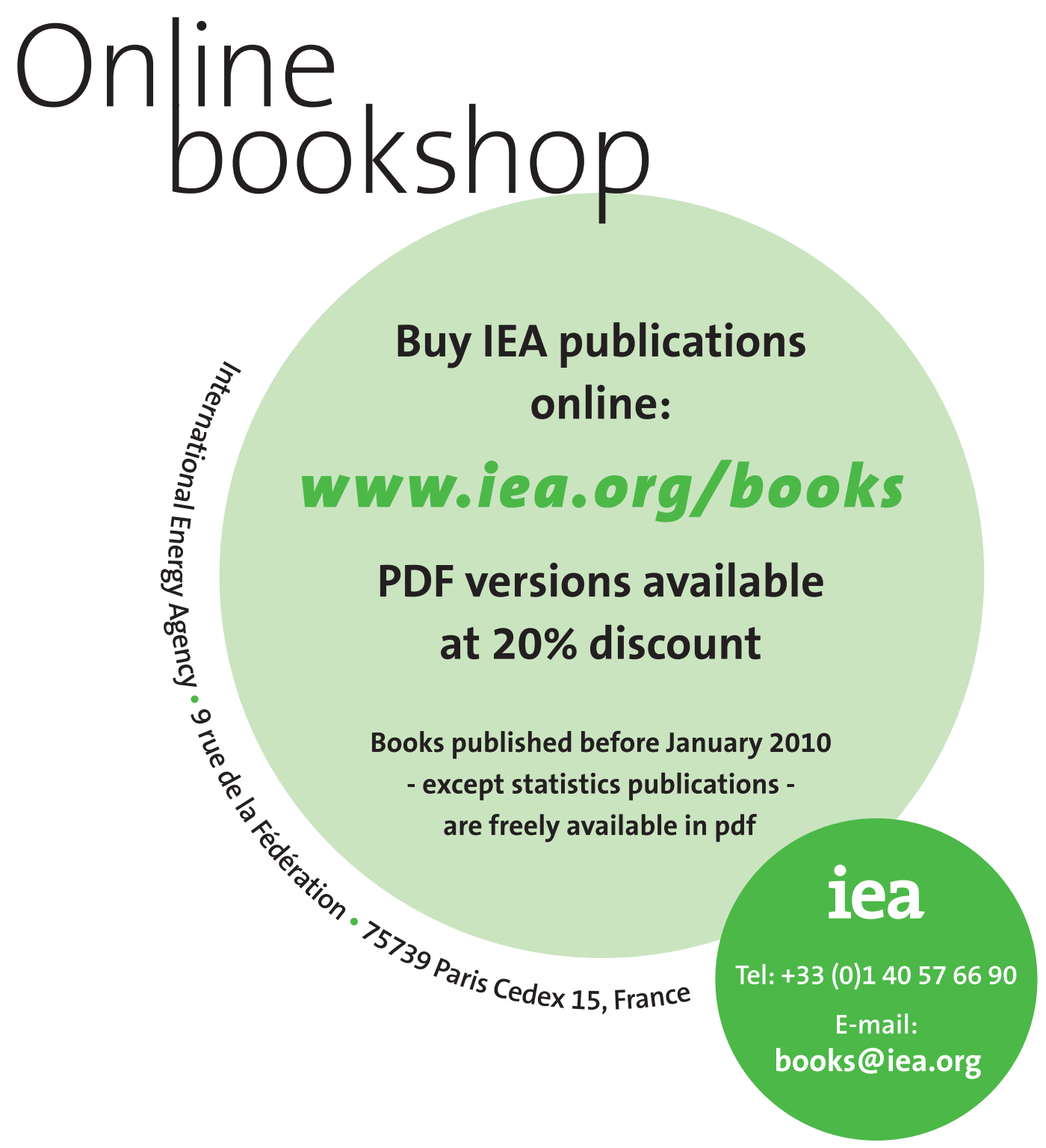


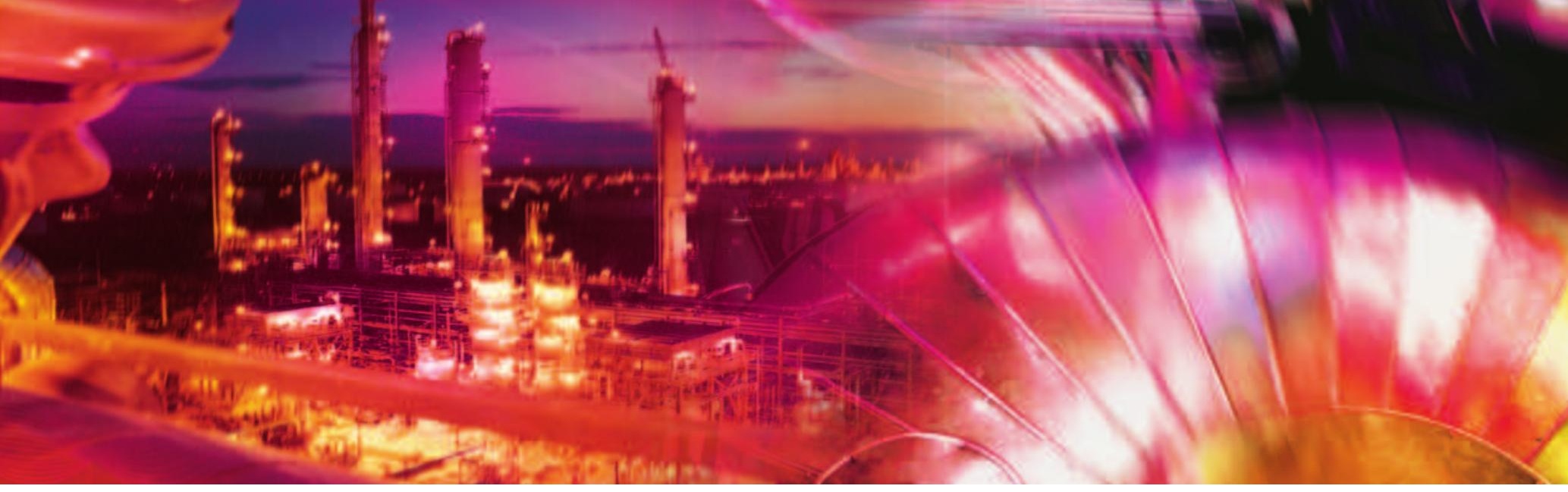

iea Energy Agency

9 rue de la Fédération

75739 Paris Cedex 15

www.iea.org 